\title{
Monograph of the Staphylinidae of Crete (Greece). Part II. Descriptions of new species (Insecta: Coleoptera)
}

With 175 figures and 2 keys

Volker Assing ${ }^{1}$, Volker Brachat ${ }^{2}$ and Heinrich Meybohm ${ }^{3}$

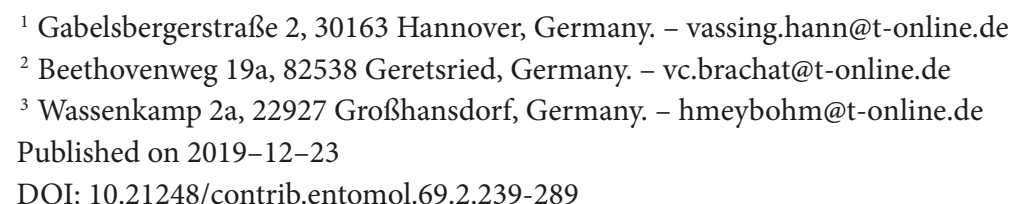

DOI: 10.21248/contrib.entomol.69.2.239-289

\section{Abstract}

One genus, Cretotyphlus Assing gen. nov., and 48 species of Staphylinidae from the Greek island Crete, 47 of them island endemics or even locally endemic, are described and illustrated: Amischa cretica Assing spec. nov., Atheta (Anopleta) digitalis Assing spec. nov., Hydrosmecta insularum Assing spec. nov. (Crete, Ikaría, Lesbos, Samothraki), Geostiba (Sipalotricha) inexsecta Assing spec. nov. (region to the east-southeast of Rethimno), Cousya candica Assing spec. nov. (East Crete: Dikti), Oxypoda (Bessopora) bimontium Assing spec. nov. (Dikti, Psiloritis), O. (Mycetodrepa) retunsa Assing spec. nov., and Typhlocyptus creticus Assing spec. nov. of the Aleocharinae; Geomitopsis cretica Assing spec. nov. (East Crete) of the Osoriinae; Allotyphlus (Moreotyphlus) foedatus Assing spec. nov. (West Crete), Kenotyphlus virgatus Assing spec. nov. (West Crete), Cretotyphlus hamatus Assing spec. nov. (East Crete: Dikti), C. chanianus Assing spec. nov. (region to the southwest of Chania), and C. idanus Assing spec. nov. (Central Crete: Psiloritis) of the Leptotyphlinae; Pseudobium creticum Assing spec. nov. of the Paederinae; Gabrius candicus Assing spec. nov. of the Staphylininae; Cephennium arcuatum Assing spec. nov. (East Crete), C. thripticum Assing spec. nov. (East Crete: Thripti), C. selinonum Assing spec. nov. (Southwest Crete), C. meybohmi Assing spec. nov. (West Crete), C. idanum Assing spec. nov. (Central Crete: Psiloritis), C. sinuosum Assing spec. nov. (East Crete), C. fortespinosum Assing spec. nov. (East Crete), C. hamulatum Assing spec. nov. (East Crete: Dikti), C. curvatum Assing spec. nov. (East Crete), C. selenanum Assing spec. nov. (East Crete: Selena Oros), C. latius Assing spec. nov. (Central Crete: Psiloritis), C. chanianum Assing spec. nov. (West Crete), Euconnus (Tetramelus) zakrius Meyвонм spec. nov. (East Crete), Stenichnus (Stenichnus) brachati Меувонм spec. nov., S. (S.) orientalis Меүвонм spec. nov. (East Crete), S. (S.) aegialioides Мечвонм spec. nov., Leptomastax cretica Меувонм spec.nov., and L. thriptica Меувонм spec. nov. (East Crete: Thripti) of the Scydmaeninae; Afropselaphus doernfeldae Brachat spec. nov. (West Crete: Lefka Ori), A. assingi Brachat spec. nov. (West Crete: Lefka Ori), A. diktianus Brachat spec. nov. (East Crete: Dikti), A. thripticus Brachat spec. nov. (East Crete: Thripti), Amauronyx chanianus Brachat spec. nov. (West Crete), A. occidens Brachat spec. nov. (West Crete), A. askifouicus Brachat spec. nov. (West Crete), Bryaxis meybohmianus Brachat spec. nov. (West Crete), Bythinus creticus Brachat spec. nov. (Central Crete: Psiloritis), Euplectus assingi BRACHAT spec. nov. (Crete), Faronus meybohmi Brachat spec. nov. (West Crete: Lefka Ori), F. lefkamontium Brachat spec. nov. (West Crete: Lefka Ori), F. albimontium Brachat spec. nov. (West Crete: Lefka Ori), and Tychus chanianus BRACHAT spec. nov. (West Crete) of the Pselaphinae; Sepedophilus creticus Schülke spec. nov. of the Tachyporinae. Keys to the species of Cephennium Müller \& Kunze, 1822 and Stenichnus Thomson, 1859 of Crete are provided. A lectotype is designated for Amauronyx paganettii Blattrý \& BLATTNÝ, 1916. 


\section{Taxonomic acts}

Cretotyphlus Assing gen. nov. - urn:lsid:zoobank.org:act:FD86523B-3B04-43D4-BD1B-40BC18EAD15F Amischa cretica Assing spec. nov. - urn:lsid:zoobank.org:act:1DBCBA49-3E09-4665-97CC-4641BB816F4E Atheta digitalis Assing spec. nov. - urn:lsid:zoobank.org:act:E1F1F8FC-708F-4C1B-AF02-5A83EC6E5A0D Hydrosmecta insularum Assing spec. nov. - urn:lsid:zoobank.org:act:A5DC3A8F-AC05-46F0-B3D0-A97CF126AB8F Geostiba inexsecta Assing spec. nov. - urn:Isid:zoobank.org:act:35864FAC-C639-4F3A-B0CA-AAB83AEBFD36 Cousya candica Assing spec. nov. - urn:lsid:zoobank.org:act:44B00621-3DA4-462B-9491-AD4B45476F2E Oxypoda bimontium Assing spec. nov. - urn:lsid:zoobank.org:act:C38F6606-DE88-4E86-B1E8-AB0921804654 Oxypoda retunsa Assing spec. nov. - urn:lsid:zoobank.org:act:D801AADC-CC6A-4E15-8988-BE8CCEA48013 Typhlocyptus creticus Assing spec. nov. - urn:lsid:zoobank.org:act:2F3A6D48-5EA3-417D-9DB3-F8E0139432F6 Geomitopsis cretica Assing spec. nov. - urn:Isid:zoobank.org:act:1D3E575E-A726-422D-BA91-AF9B98BCA2BD Allotyphlus foedatus Assing spec. nov. - urn:lsid:zoobank.org:act:42A89E7C-F33A-43C8-A301-296D27AD2BBF Kenotyphlus virgatus Assing spec. nov. - urn:lsid:zoobank.org:act:1967E04F-CD26-4976-928F-B9A195790332 Cretotyphlus hamatus Assing spec. nov. - urn:lsid:zoobank.org:act:EBE1B406-3145-411C-883D-A9499AEF52BA Cretotyphlus chanianus Assing spec. nov. - urn:lsid:zoobank.org:act:1D048CF4-D0DE-4839-869F-4D96B269F25C Cretotyphlus idanus Assing spec. nov. - urn:lsid:zoobank.org:act:993DEFB4-903E-4367-96DD-6F4D8F0DE42F Pseudobium creticum Assing spec. nov. - urn:lsid:zoobank.org:act:98EA1ABE-EA17-4F90-A7BF-6069D9FDF481 Gabrius candicus Assing spec. nov. - urn:lsid:zoobank.org:act:4FAC0FC1-20F7-4DC4-BAA9-FBC4DDF3175D Cephennium arcuatum Assing spec. nov. - urn:lsid:zoobank.org:act:7A3212BC-0311-49F7-A2AB-C529B6CD42A9 Cephennium thripticum Assing spec. nov. - urn:lsid:zoobank.org:act:6681B4E6-3602-47F6-82BF-C1C9FD0E6A45 Cephennium selinonum Assing spec. nov. - urn:lsid:zoobank.org:act:5C1D00CC-C8A3-4043-92A9-773137CD17CB Cephennium meybohmi Assing spec. nov. - urn:lsid:zoobank.org:act:BDCAA375-E045-47F7-AC38-6812249B9A7C Cephennium idanum Assing spec. nov. - urn:lsid:zoobank.org:act:C7F685DD-32CC-4AF7-AA4E-4B3096D86B13 Cephennium sinuosum Assing spec. nov. - urn:lsid:zoobank.org:act:C89E57D1-33EB-4693-BF85-27EAC289A064 Cephennium fortespinosum Assing spec. nov. - urn:lsid:zoobank.org:act:C84F5038-F12C-48CC-9ED7-8DBE6BAE1D5C Cephennium hamulatum Assing spec. nov. - urn:lsid:zoobank.org:act:FA4D9AB5-DAA3-4DE7-8064-5B98210F93D0 Cephennium curvatum Assing spec. nov. - urn:lsid:zoobank.org:act:73B78F2A-4907-4334-B475-A59C7CD81063 Cephennium selenanum Assing spec. nov. - urn:lsid:zoobank.org:act:E5B87D2D-9402-43F9-82E3-1DEF6D709DF1 Cephennium latius Assing spec. nov. - urn:lsid:zoobank.org:act:8B3A0458-1D50-4551-BED6-D307750DD522 Cephennium chanianum Assing spec. nov. - urn:lsid:zoobank.org:act:0C990A58-8107-4B07-87D5-FE0541CD444 Euconnus zakrius Меувонм spec. nov. - urn:lsid:zoobank.org:act:506C3D6D-FD24-4484-813D-F00E761EFECB Stenichnus brachati МЕувонм spec. nov. - urn:lsid:zoobank.org:act:0D694A13-AB82-4398-AC2A-2E4D39B515FB Stenichnus orientalis Mеувонм spec. nov. - urn:lsid:zoobank.org:act:06558FCA-3A62-4019-BFB7-EF06448C1956 Stenichnus aegialioides МеҮвонм spec. nov. - urn:lsid:zoobank.org:act:712D1FB1-7AB4-4C27-8CB2-05E07E8435FE Leptomastax cretica Меувонм spec. nov. - urn:lsid:zoobank.org:act:444B05D8-E8CB-4F7F-A9A5-1695EB36C08A Leptomastax thriptica Меувонм spec. nov. - urn:lsid:zoobank.org:act:5EA83082-7F64-4122-852C-AECB11BF6D01 AfropselaphusdoernfeldaeBRACHATspec. nov.-urn:lsid:zoobank.org:act:96DFC249-A208-44CE-BC83-4BB829F6966B Afropselaphus assingi BRACHAT spec. nov. - urn:lsid:zoobank.org:act:A29A770B-1104-4BB0-BA7E-ADA1CB04D204 Afropselaphus diktianus BRACHAT spec. nov. - urn:lsid:zoobank.org:act:AF308CB8-7539-4626-8E2C-DD2A7E9B5052 Afropselaphus thripticus BRACHAT spec. nov. - urn:lsid:zoobank.org:act:E38E8556-0E8F-4C12-BD99-3759694D8E82 Amauronyx chanianus BRACHAT spec. nov. - urn:lsid:zoobank.org:act:833A774F-4626-4CC8-8BE0-7B857E33EC43 Amauronyx occidens BRACHAT spec. nov. - urn:lsid:zoobank.org:act:0545A123-B114-4014-A05D-2C5EF565D5D9 Amauronyx askifouicus BRACHAT spec. nov. - urn:lsid:zoobank.org:act:7CE4D2AD-8F1E-408A-9112-5301AC6CC6AE Bryaxis meybohmianus BRACHAT spec. nov. - urn:lsid:zoobank.org:act:FE6B56D3-E7A1-4F55-9587-ABC42768A1AC Bythinus creticus BRACHAT spec. nov. - urn:lsid:zoobank.org:act:5A5439A5-BB04-41D0-897E-3769BA046964 Euplectus assingi BRACHAT spec. nov. - urn:lsid:zoobank.org:act:B653CFCD-0DF4-4AC8-8BDC-64FCD2FB9599 Faronus meybohmi BRACHAT spec. nov. - urn:lsid:zoobank.org:act:B80022A7-78AC-45E9-94A6-B3A31657DCF7 Faronus lefkamontium BRACHAT spec. nov. - urn:lsid:zoobank.org:act:B5C36287-54F6-4CF0-B2BF-E3D8E4AF1029 Faronus albimontium BRACHAT spec. nov. - urn:lsid:zoobank.org:act:9E7893E5-D3A1-4387-B179-AA51AB793FED Tychus chanianus BRACHAT spec. nov. - urn:lsid:zoobank.org:act:85D07E45-AEE2-4D13-9C26-18B353D1AD15 Sepedophilus creticus SCHÜLKE spec. nov. - urn:lsid:zoobank.org:act:F2B971D6-B222-4823-A1BB-DF4B816F0775

\section{Key words}

Coleoptera, Staphylinidae, Palaearctic region, East Mediterranean, Greece, Crete, taxonomy, endemism, endogean fauna, new genus, new species, key to species, lectotype designation 


\section{Zusammenfassung}

Eine Gattung, Cretotyphlus Assing gen. nov., und 48 Arten der Staphylinidae von der griechischen Insel Kreta, davon 47 Insel- oder Lokalendemiten, werden beschrieben und abgebildet: Amischa cretica Assing spec. nov., Atheta (Anopleta) digitalis Assing spec. nov., Hydrosmecta insularum Assing spec. nov. (Kreta, Ikaría, Lesbos, Samothraki), Geostiba (Sipalotricha) inexsecta Assing spec. nov. (Gebiet ost-südöstlich von Rethimno), Cousya candica Assing spec. nov. (Ostkreta: Dikti), Oxypoda (Bessopora) bimontium Assing spec. nov. (Dikti, Psiloritis), O. (Mycetodrepa) retunsa Assing spec. nov. und Typhlocyptus creticus Assing spec. nov. aus der Unterfamilie Aleocharinae; Geomitopsis cretica Assing spec. nov. (Ostkreta) (Osoriinae); Allotyphlus (Moreotyphlus) foedatus Assing spec. nov. (Westkreta), Kenotyphlus virgatus Assing spec. nov. (Westkreta), Cretotyphlus hamatus Assing spec. nov. (Ostkreta: Dikti), C. chanianus Assing spec. nov. (Gebiet südwestlich von Chania) und C. idanus Assing spec. nov. (Zentralkreta: Psiloritis) aus der Unterfamilie Leptotyphlinae; Pseudobium creticum Assing spec. nov. (Paederinae); Gabrius candicus Assing spec. nov. (Staphylininae); Cephennium arcuatum Assing spec. nov. (Ostkreta), C. thripticum Assing spec. nov. (Ostkreta: Thripti), C. selinonum Assing spec. nov. (Südwestkreta), C. meybohmi Assıng spec. nov. (Westkreta), C. idanum Assing spec. nov. (Zentralkreta: Psiloritis), C. sinuosum Assing spec. nov. (Ostkreta), C. fortespinosum Assing spec. nov. (Ostkreta), C. hamulatum Assing spec. nov. (Ostkreta: Dikti), C. curvatum Assing spec. nov. (Ostkreta), C. selenanum Assing spec. nov. (Ostkreta: Selena Oros), C. latius Assing spec. nov. (Zentralkreta: Psiloritis), C. chanianum Assing spec. nov. (Westkreta), Euconnus (Tetramelus) zakrius Mеувонм spec. nov. (Ostkreta), Stenichnus (Stenichnus) brachati Меүвонм spec. nov., S. (S.) orientalis Меүвонм spec. nov. (Ostkreta), S. (S.) aegialioides Меувонм spec. nov., Leptomastax cretica Меувонм spec. nov. und L. thriptica Mеувонм spec. nov. (Ostkreta: Thripti) aus der Unterfamilie Scydmaeninae; Afropselaphus doernfeldae Brachat spec. nov. (Westkreta: Lefka Ori), A. assingi Brachat spec. nov. (Westkreta: Lefka Ori), A. diktianus Brachat spec. nov. (Ostkreta: Dikti), A. thripticus Brachat spec. nov. (Ostkreta: Thripti), Amauronyx chanianus BRACHAT spec. nov. (Westkreta), A. occidens BRACHAT spec. nov. (Westkreta), A. askifouicus Brachat spec. nov. (Westkreta), Bryaxis meybohmianus Brachat spec. nov. (Westkreta), Bythinus creticus BrACHAT spec. nov. (Zentralkreta: Psiloritis), Euplectus assingi BraCHAT spec. nov. (Kreta), Faronus meybohmi Brachat spec. nov. (Westkreta: Lefka Ori), F. lefkamontium Brachat spec. nov. (Westkreta: Lefka Ori), F. albimontium BrACHAT spec. nov. (Westkreta: Lefka Ori) und Tychus chanianus BRACHAT spec. nov. (Westkreta) aus der Unterfamilie Pselaphinae; Sepedophilus creticus SchüLKe spec. nov. (Tachyporinae). Für die von Kreta nachgewiesenen Arten der Gattungen Cephennium Müller \& Kunze, 1822 und Stenichnus Thomson, 1859 werden Bestimmungstabellen erstellt. Für Amauronyx paganettii BlatTwÝ \& BlatTNÝ, 1916 wird ein Lektotypus designiert.

\section{Schlüsselwörter}

Coleoptera, Staphylinidae, Paläarktis, Ostmediterraneis, Griechenland, Kreta, Taxonomie, Endemismus, endogäische Fauna, Beschreibungen, neue Gattung, neue Arten, Bestimmungsschlüssel, Lektotypendesignation

\section{Introduction}

While the first part of the monograph of the Cretan Staphylinidae fauna focused on diversity, endemism, and biogeographic aspects, this supplement provides descriptions of one genus and as many as 48 new species. With one exception, all of them are endemic to Crete. Where deemed necessary, data on similar species distributed in regions other than Crete are provided.

For further details on the geology, geography, biodiversity, endemism, sample localities, sampling methods, etc. see the first part of the monograph (Assing 2019c).

The descriptions of Pselaphinae and Scydmaeninae, exclusive of Cephennium Müller \& Kunze, 1822, are authored by the second and third author, respectively, that of Sepedophilus creticus by Michae Schülke, and the remainder (including Cephennium) by the first author.

\section{Material and methods}

The material treated in this study is deposited in the following public and private collections:

\section{MNB Museum für Naturkunde Berlin (J. Frisch)}

NHMB Naturhistorisches Museum Basel (C. Germann) NHMW Naturhistorisches Museum Wien (H. Schillhammer)

cAss private collection Volker Assing, Hannover

cBra private collection Volker Brachat, Geretsried

cFel private collection Benedikt Feldmann, Münster

cHla private collection Peter Hlaváč, Prague

cMat private collection Jan Matějíček, Hradec Králové

cMey private collection Heinrich Meybohm, Großhansdorf

cWun private collection Paul Wunderle, Mönchengladbach 
For the species described by the first author, a Stemi SV 11 microscope (Zeiss), a Discovery V12 microscope (Zeiss), and a Jenalab compound microscope (Carl Zeiss Jena) were used. The images were created using digital cameras (Nikon Coolpix 995, Axiocam ERc 5s), as well as Labscope and Picolay stacking software.

The photos provided by the second and third authors (Pselaphinae, Scydmaeninae exclusive of Cephennium spp.) were produced with the help of Thure Dalsgaard, Zoological Museum Hamburg, using various photographic equipment at his disposal.

Measurements: body length was measured from the anterior margin of the mandibles (in resting position) or the labrum (whichever forms the anterior apex of the head) to the posterior apex of the elytra (Scydmaeninae) or to the abdominal apex (other subfamilies), the length of the forebody from the apex of the head to the posterior margin of the elytra (all subfamilies except Scydmaeninae), head length along the middle from the anterior margin of the clypeus (without ante-clypeus) (Aleocharinae) or from the anterior margin of the frons (other subfamilies) to the posterior constriction of the head, elytral length at the suture from the apex of the scutellum to the posterior margin of the elytra, and the length of (the median lobe of) the aedeagus from the apex of the median lobe (without internal structures) or the apices of parameres (whichever extends farther) to the base of the median lobe (Pselaphinae) or from the apex of the ventral process to the base of the aedeagal capsule (other subfamilies). The "parameral" side (i.e., the side where the sperm duct enters) is referred to as the ventral, the opposite side as the dorsal aspect.

\section{Descriptions}

\section{Aleocharinae}

\section{Amischa cretica Assing spec. nov.}

urn:Isid:zoobank.org:act:1DBCBA49-3E09-4665-97CC-4641BB816F4E (Figs 1-11)

Type material: Holotype $0^{\star}:$ "GR - Crete [34], Orno Thriptis, E Thripti, 350' $35^{\prime \prime N}, 25^{\circ} 52^{\prime} 36^{\prime \prime E}, 970 \mathrm{~m}$, under stones, 6.IV.2012, V. Assing / Holotypus ơ Amischa cretica sp. n. det. V. Assing 2018" (cAss). Paratypes: $10^{*}$ : same data as holotype (cAss); 1 : :GR - Crete [3], Orno Thriptis, E Thripti, 3505'34"N, 2552'41"E, 970 m, under stones, 25.XII.2017, V. Assing" (cAss); 6 주 o $^{\star}, 4$ 우 우: "N3519'22 E2353'33, GR Kreta 1050 m, Omalos S 25.3.2019, Brachat \& Meybohm (21)" (cAss).

Etymology: The specific epithet (adjective) alludes to the fact that this species is at present known only from Crete.

Description: Body length 2.2-2.4 mm; length of forebody $1.00-1.15 \mathrm{~mm}$. Habitus as in Fig. 1. Coloration: head black; pronotum and elytra dark-brown; abdomen blackish-brown with the posterior margins of the segments brown; legs yellow; antennae blackish-brown with antennomeres I-II dark-yellowish.

Head (Fig. 2) weakly transverse; punctation rather dense and extremely fine, invisible in the pronounced microsculpture even at a magnification of $100 \mathrm{x}$. Eyes approximately as long as postocular portion in dorsal view. Antenna (Fig. 3) approximately $0.6 \mathrm{~mm}$ long; antennomeres IV weakly transverse, V-X of gradually increasing width and increasingly transverse, and $\mathrm{X}$ approximately 1.5 times as broad as long.

Pronotum (Fig. 2) approximately 1.2 times as broad as long and 1.25 times as broad as head; punctation and microsculpture similar to those of head.

Elytra (Fig. 2) slightly shorter than pronotum; punctation dense and fine, more distinct than that of pronotum; interstices with shallow microsculpture. Hind wings fully developed.

Abdomen slightly narrower than elytra; punctation dense and fine, nearly as dense on tergite VII as on anterior tergites; microsculpture present, more distinct on tergite VII than on anterior tergites; posterior margin of tergite VII with palisade fringe.

$\sigma^{\star}$ : tergite VIII (Fig. 4) transverse, its posterior margin deeply, broadly triangularly excised; sternite VIII (Fig. 5) much longer than tergite VIII, slightly longer than broad, posteriorly with a pair of long black submarginal setae, posterior margin convex, in the middle indistinctly concave; median lobe of aedeagus (Figs 6-8) $0.36 \mathrm{~mm}$ long, with pronounced crista apicalis; internal sac basally with a pair of pronounced and strongly curved (hookshaped) spines.

ㅇ: tergite VIII (Fig. 9) nearly as long as broad, longer than that of male, posterior excision of similar shape as in male, but less deep; sternite VIII (Fig. 10) approximately as long as broad, slightly longer than tergite VIII, posterior margin convex and with moderately modified short yellowish marginal setae; spermatheca as in Fig. 11.

Comparative notes: Amischa cretica is characterized particularly by the secondary sexual characters and by the morphology of the median lobe of the aedeagus, especially the shapes of the ventral process, of the crista apicalis, and of the basal internal structures. Regarding the sexual characters, the species is most similar to A. corsica BenICK, 1967 (Corsica) and A. otini Peyerimhoff, 1949 (Morocco) (type material of both species examined). Amischa cretica is distinguished from them as follows:

from $A$. corsica (female not available) by the shape of the male sternite VIII (A. corsica: posterior margin distinctly concave in the middle), a much deeper posterior excision of the shorter and more strongly transverse male tergite VIII, and by a smaller median lobe of the aedeagus with a distinctly bisinuate (lateral view) and more slender (ventral view) ventral process, and by the hook-shaped basal internal structures (A. corsica: median lobe approximately $0.4 \mathrm{~mm}$ long, with basal three-fourths of ventral 
process nearly straight in ventral view and with smoothly curved basal internal structures);

from A. otini (female unknown) by longer elytra, a smaller and in ventral view basally more slender aedeagus with a shorter ventral process, a more pronounced crista apicalis, and with stout and hook-shaped basal spines in the internal sac (A. otini: median lobe $0.4 \mathrm{~mm}$ long; basal internal structures very thin, not hook-shaped, and weakly sclerotized), and by a shorter male tergite VIII with a deeper posterior excision of different shape (A. otini: posterior excision smoothly concave).

The new species is readily distinguished from the widespread and common A. bifoveolata (MANNERHEIM, 1830), A. decipiens (Sharp, 1869), and A.forcipata Mulsant \& ReY, 1873, as well as from the similarly widespread and common, but parthenogenetic A. analis (GRAVENHorst, 1802) and A.nigrofusca (Stephens, 1832) by the completely different shapes of the male and female tergites and sternites VIII alone.

Distribution and natural history: All type specimens were collected in two localities, one in Orno Thriptis, East Crete, and one in Lefka Ori, West Crete. The specimens from the type locality, which is identical to those of Myrmecopora thriptica, Astenus thripticus, and Sunius thripticus (three local endemics of the Orno Thriptis), were found under stones in a moist stony pasture at an altitude of $970 \mathrm{~m}$. For a photo of the type locality see figure 78 in Assing (2013). The specimens from Lefka Ori were sifted from Berberis litter at an altitude of $1050 \mathrm{~m}$.

\section{Atheta (Anopleta) digitalis Assing spec. nov. urn:Isid:zoobank.org:act:E1F1F8FC-708F-4C1B-AF02-5A83EC6E5A0D (Figs 12-19)}

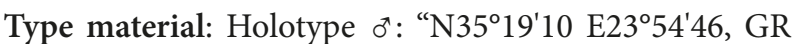
Westkreta (16), Omalos $1110 \mathrm{~m}$ 16.3.2018, 1. Brachat \& Meybohm / Holotypus $\sigma^{\top}$ Atheta digitalis sp. n. det. V. Assing 2018" (cAss). Paratypes: 1 + : same data as holotype (cAss); 1 o': "GR - Crete [17a], NW Dikti Oros, Limnakaro, $35^{\circ} 08^{\prime} 08^{\prime \prime} \mathrm{N}, \quad 25^{\circ} 29^{\prime} 00^{\prime \prime} \mathrm{E}, 1170 \mathrm{~m}$, sifted, 30.III.2012, V. Assing” (cAss).

Etymology: The specific epithet (Latin, adjective: of a finger) alludes to the shape of one of the internal structures of the aedeagus.

Description: Body length $2.2-2.3 \mathrm{~mm}$; length of forebody $0.9-1.1 \mathrm{~mm}$. Habitus as in Fig. 12. Coloration: body black; legs dark-brown to blackish-brown with the bases and apices of the tibiae and all of the tarsi pale yellowish; antennae black.

Head (Fig. 13) weakly transverse, with or without very shallow impression in the middle; punctation moderately dense and extremely fine, barely visible even at a magnification of $100 \mathrm{x}$; interstices with pronounced microreticulation. Eyes large, as long as, or slightly longer than postocular portion in dorsal view. Antenna (Fig. 14) approximately $0.6 \mathrm{~mm}$ long; antennomere IV weakly transverse; antennomeres $\mathrm{V}-\mathrm{X}$ of gradually increasing width and increasingly transverse, $\mathrm{X}$ approximately 1.5 times as broad as long.

Pronotum (Fig. 13) small, approximately 1.2 times as broad as long and 1.1 times as broad as head; punctation and microsculpture similar to those of head; pubescence white, directed transversely laterad in lateral portion and apparently (difficult to assess in type specimens) anteriad in anterior third and posteriad in posterior two-thirds of midline.

Elytra (Fig. 13) approximately 1.2 times as long as pronotum; punctation and microsculpture similar to those of head and pronotum.

Abdomen (Fig. 15) narrower than elytra, broadest at segment VI; punctation fine, denser on anterior than on posterior tergites; all tergites with pronounced isodiametric microsculpture, but glossy; posterior margin of tergite VII with palisade fringe; tergite VIII subject to sexual dimorphism.

$\sigma^{*}$ : posterior margin of tergite VIII (Fig. 16) truncate to weakly concave and crenulate; sternite VIII with moderately convex posterior margin; median lobe of aedeagus (Figs 17-18) small, $0.23 \mathrm{~mm}$ long; crista apicalis pronounced; internal structures of distinctive shape, the less sclerotized one shaped like a finger in lateral view.

+ : posterior margin of tergite VIII of similar shape as in male, but posterior margin not crenulate; posterior margin of sternite VIII less convex than in male; spermatheca (Fig. 19) small and of highly distinctive shape, distal portion strongly dilated.

Comparative notes: Based on the similar sexual characters, $A$. digitalis appears to be closely allied to A. puberula (SHARP, 1869). It is distinguished from this species by significantly smaller size (A. puberula: body length 2.5-2.8 mm), shorter antennae, the coloration of the legs (yellow in A. puberula), and by the primary and secondary sexual characters. In $A$. puberula, the posterior margin of the male tergite VIII is more concave and has a distinct lateral tooth on either side, the posterior margin of the male sternite VIII is strongly convex, the median lobe of the aedeagus is much larger (A. puberula: median lobe approximately $0.35 \mathrm{~mm}$ long) and has differently shaped internal structures, the posterior margin of the female sternite VIII has a pronounced median concavity, and the spermatheca is much larger and of different shape.

Distribution and natural history: This species is currently known from two localities, one in West Crete and one in the east of the island. The specimen from East Crete was recorded as Atheta (Microdota) sp. by Assing (2013). The specimens were sifted from litter at an altitude of $1110 \mathrm{~m}$ (specimens from the type locality) and from grass, litter, and moss near snowfields at an altitude of $1170 \mathrm{~m}$ (male from Dikti). 
Hydrosmecta insularum Assing spec. nov. urn:Isid:zoobank.org:act:A5DC3A8F-AC05-46F0-B3D0-A97CF126AB8F (Figs 20-31)

Type material: Holotype ơ : "GR - Crete [59], WSW Ag. Nikolaos, Katharo plateau, 1100 m, stream, 3508'19"N, 2533'36"E, 27.III.2018, V. Assing / Holotypus o Hydrosmecta insularum sp. n. det. V. Assing 2018" (cAss). Paratypes: $39 \sigma^{\top} \sigma^{\star}, 37$ ㅇ ㅇ: same data as holotype (cAss, MNB); 3 o $^{\star}, 9$ ㅇ ㅇ : “GR - Crete [60], WSW Ag. Nikolaos, Katharo plateau, 1090 m, stream, 350' $48^{\prime \prime N}, 25^{\circ} 33^{\prime} 33^{\prime \prime E}$, 27.III.2018, V. Assing" (cAss, MNB); 41 o $^{\star} 0^{\star}, 44$ 우 "GR - Crete [61], WSW Ag. Nikolaos, Katharo plateau, $1110 \mathrm{~m}$, stream, $35^{\circ} 08^{\prime} 14^{\prime} \mathrm{N}, 25^{\circ} 34^{\prime} 15^{\prime \prime} \mathrm{E}, 28 . I I I .2018$, V. Assing” (cAss, cFel); 16 o $^{\star} o^{\star}, 16$ 우: “GR - Crete [12], WSW Ag. Nikolaos, Katharo plateau, 1110 m, stream, 350' $14 " \mathrm{~N}, 25^{\circ} 34^{\prime} 15^{\prime \prime E}, 10 . I V .2014$, V. Assing" (cAss, MNB); 8 ㅇ 우 : “GREECE: Ikaría [18], NE Pezi, 37³3'51"N, 2604'46"E, $860 \mathrm{~m}$, stream bank, floated, 12.IV.2017, V. Assing” (cAss, MNB); $20^{*} 0^{*}$ : “GREECE: Lesbos [27a] $16 \mathrm{~km}$ ENE Kalloni, 39¹5'02"N, 2623'14"E, $120 \mathrm{~m}$, 24.III.2016, V. Assing \& A. Hetzel" (cAss); $10^{\star}:$ :GR Samothraki [16a], W Lakkoma, 40²5'57"N, 2530'54"E, $20 \mathrm{~m}$, gravel river bank, 16.IV.2019, V. Assing” (cAss); $7 \sigma^{\top} \sigma^{*}, 10$ 우 우 “GR - Samothraki [33], SE Ano Meria, $40^{\circ} 26^{\prime} 52^{\prime \prime N}, 25^{\circ} 41^{\prime} 46^{\prime \prime E}, 5 \mathrm{~m}$, stream gravel, 14.IV.2019, V. Assing" (cAss, MNB); 6 우: "GR - Samothraki [34b], ESE Ano Meria, 40²7'41"N, 2541'25"E, $30 \mathrm{~m}$, stream gravel, 17.IV.2019, V. Assing” (cAss, MNB); 1 : "GR - Samothraki [38a], SE Kamariotissa, 40²6'48"N, 2529'53"E 40 m, stream gravel, 16.IV.2019, V. Assing” (cAss).

Etymology: The specific epithet is the genitive plural of the Latin noun insula (island) and reflects the fact that this species is currently known only from islands.

Description: Body length 2.2-2.9 mm; length of forebody 1.1-1.3 mm. Habitus as in Fig. 20. Coloration: body black with the elytra slightly paler; legs yellowish to darkyellowish; antennae blackish-brown to black.

Head (Fig. 21) approximately as broad as long or weakly transverse; punctation dense and fine, barely visible in the pronounced microreticulation. Eyes large, much longer than postocular portion in dorsal view. Antenna (Fig. 22) approximately $0.9 \mathrm{~mm}$ long; antennomeres III shorter than II, IV distinctly oblong, approximately 1.5 times as long as broad, $\mathrm{V}-\mathrm{X}$ distinctly oblong, but less than twice as long as broad, and XI approximately three times as long as broad.

Pronotum (Fig. 21) 1.15-1.20 times as broad as long and 1.10-1.15 times as broad as head, broadest anterior to middle; disc weakly convex in cross-section, in the middle depressed or shallowly impressed; pubescence directed anteriad along midline and transversely laterad in lateral portions; punctation dense and extremely fine, finer than that of head; disc with pronounced microreticulation.
Elytra (Fig. 21) approximately as long as pronotum; punctation very dense and fine; interstices with microsculpture. Hind wings fully developed.

Abdomen narrower than elytra; anterior impressions of tergites III-V shallow; punctation fine and moderately dense, denser on anterior than on posterior tergites; interstices with distinct microreticulation; posterior margin of tergite VII with palisade fringe; tergite and sternite VIII with pronounced sexual dimorphism.

$\mathrm{o}^{\star}$ : tergite VIII (Fig. 23) distinctly transverse, posterior margin more or less truncate; sternite VIII (Fig. 24) much longer than tergite VIII, its posterior margin weakly concave, nearly truncate; median lobe of aedeagus (Figs 25-27) 0.32-0.36 mm long and of highly distinctive shape; paramere (Fig. 28) slightly longer than median lobe and not distinctly modified.

: tergite VIII (Fig. 29) less transverse than in male, but with posterior margin of similar shape; sternite VIII (Fig. 30) slightly longer than tergite VIII, its posterior margin convex and in the middle distinctly concave; spermatheca distinctive (Fig. 31).

Comparative notes: Based on the modifications of the abdominal segment VIII and on the derived morphology of the median lobe of the aedeagus, $H$. insularum belongs to Hydrosmecta sensu strictu. It is distinguished from other species of this group especially by the conspicuous shape of the median lobe of the aedeagus. In addition, it is characterized by the male secondary sexual characters (shape of sternite VIII) and by the shape of the spermatheca.

Distribution and natural history: The currently known distribution is confined to the Greek islands Crete, Ikaría, Lesbos, and Samothraki. The species was reported from Lesbos as Hydrosmecta sp. 2 in Assing (2016) and from Ikaría as Hydrosmecta sp. in Assing (2017). The specimens were washed from fine gravel along small streams at altitudes of $110-1110 \mathrm{~m}$.

\section{Geostiba (Sipalotricha) inexsecta Assing spec. nov. urn:Isid:zoobank.org:act:35864FAC-C639-4F3A-BOCA-AAB83AEBFD36 (Figs 32-38)}

Type material: Holotype $\sigma^{*}$ : "GR - Crete [12], ESE

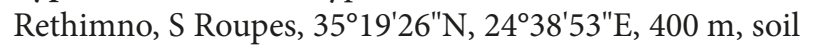
washing, 26.XII.2018, V. Assing / Holotypus o Geostiba inexsecta sp. n. det. V. Assing 2019” (cAss). Paratypes: $4 o^{\star} o^{\star}, 6$ 9 : : same data as holotype (cAss); 1 : “GR Crete [13], ESE Rethimno, S Arkadi M., 35²17'51"N, $24^{\circ} 38^{\prime} 08^{\prime E}$, $520 \mathrm{~m}$, soil washing, 26.XII.2018, V. Assing" (cAss).

Etymology: The specific epithet (Latin, adjective) alludes to the absence of a distinct posterior excision of the male tergite VIII. 


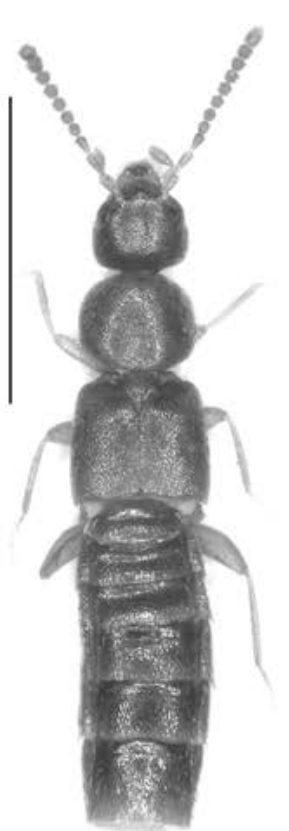

1

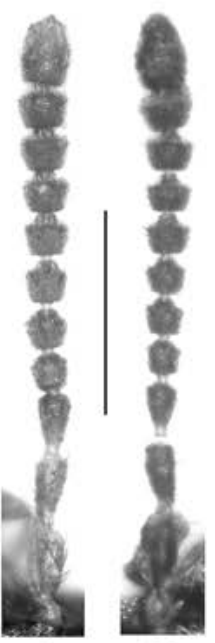

3

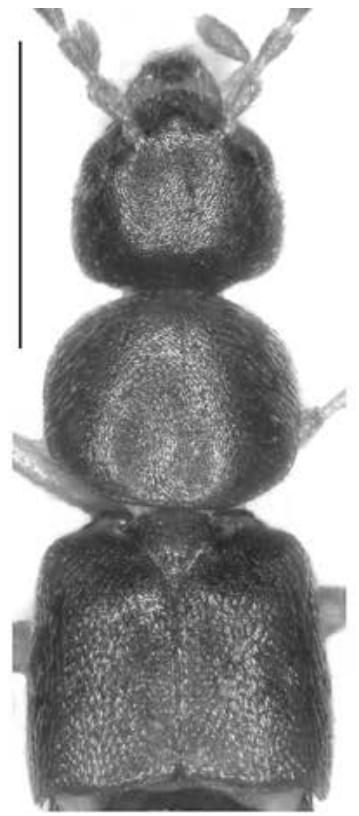

2

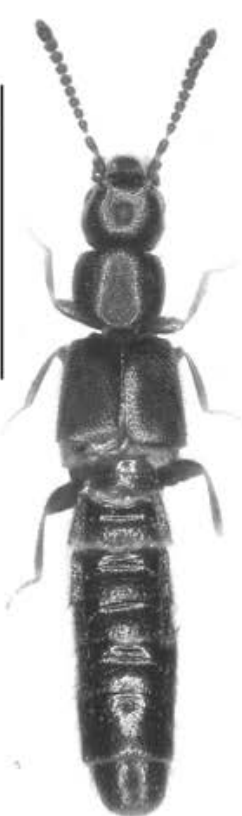

12

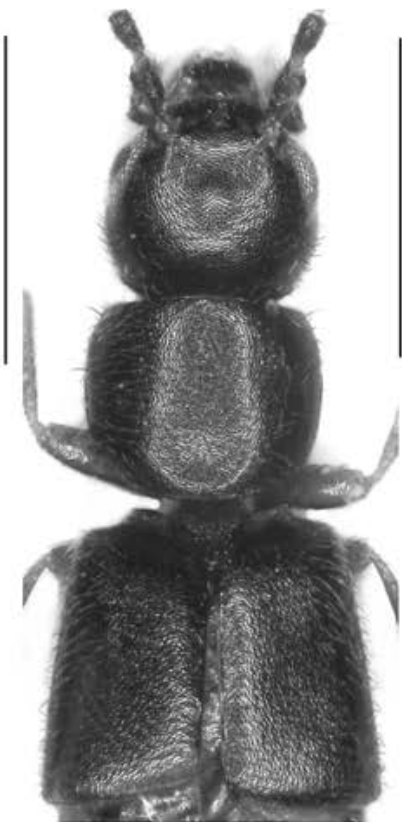

13

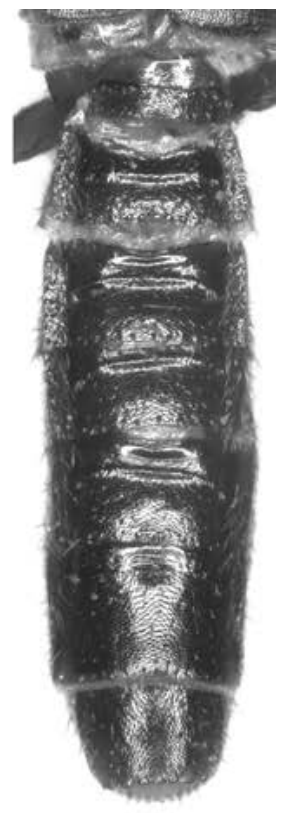

15

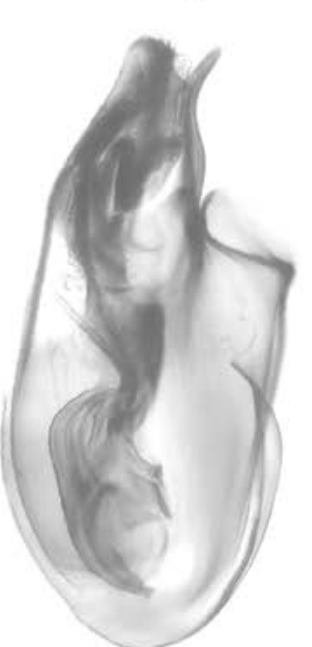

6

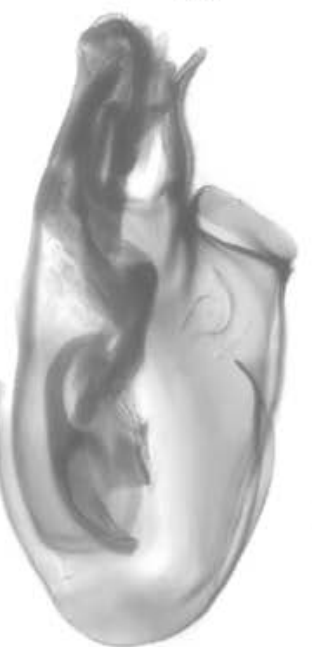

7

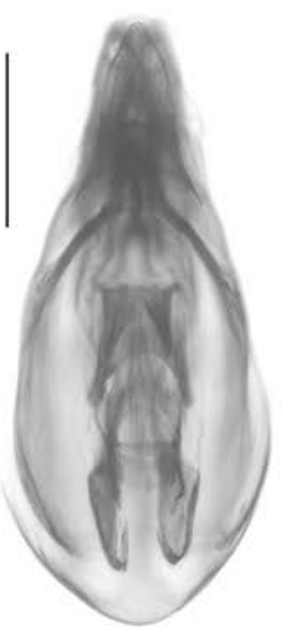

8
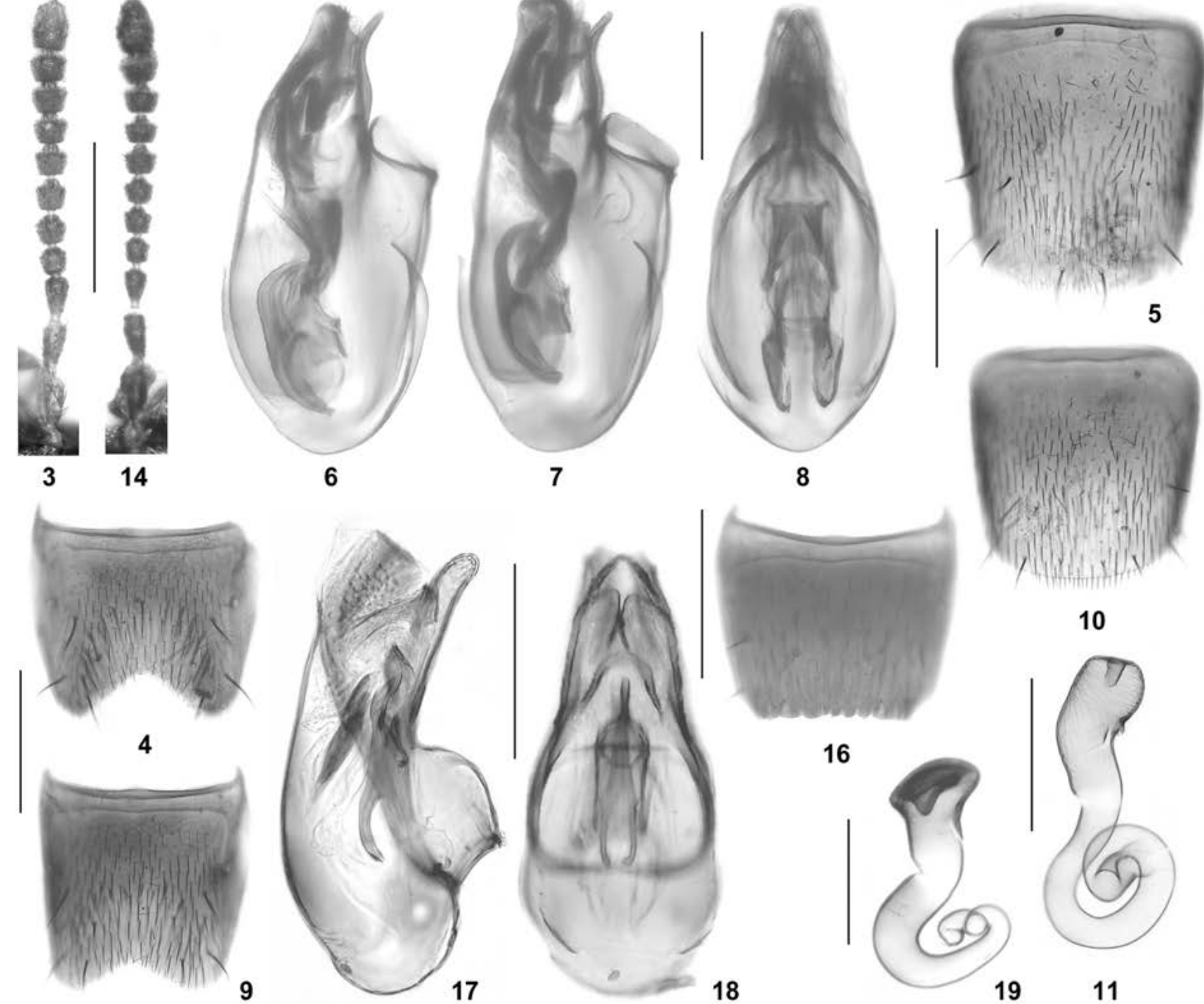

5
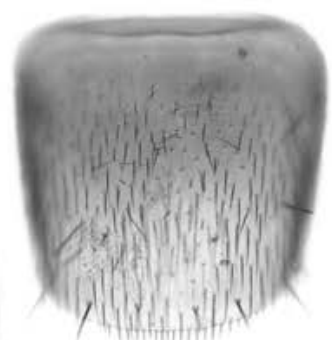

10

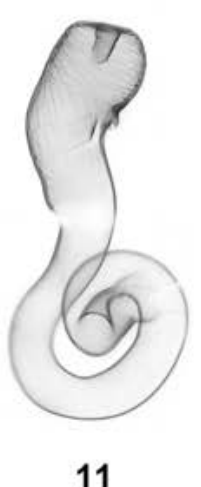

$19 \quad 11$

Figs 1-19: Amischa cretia (1-11) and Atheta digitalis (12-19): habitus (1, 12); forebody $(2,13)$; antenna $(3,14)$; male tergite VIII $(4,16)$; male sternite VIII $(5)$; median lobe of aedeagus in lateral and in ventral view $(6-8,17-18)$; female tergite VIII $(9)$; female sternite VIII (10); spermatheca $(11,19)$; abdomen (15). Scale bars: 1, 12: $1.0 \mathrm{~mm}$; 2, 13, 15: $0.5 \mathrm{~mm}$; 3-5, 9-10, 14, 16: 0.2 mm; 6-8, 11, 17-19: $0.1 \mathrm{~mm}$. 


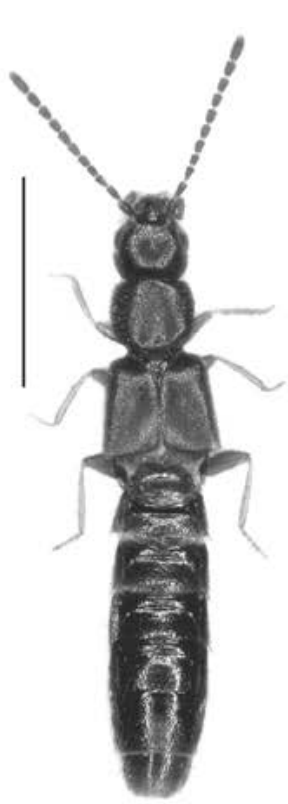

20

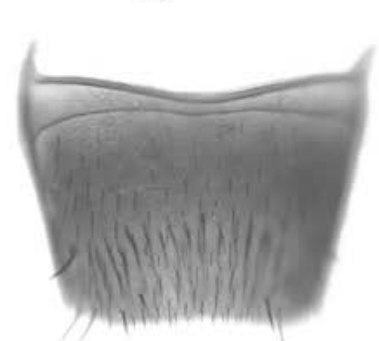

23

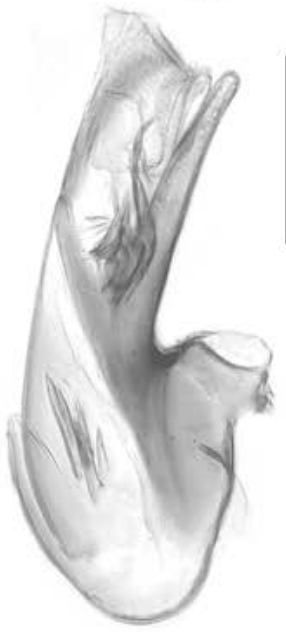

34

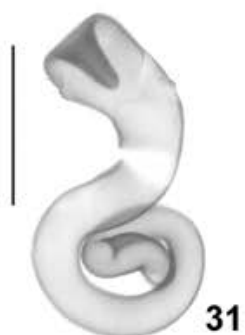

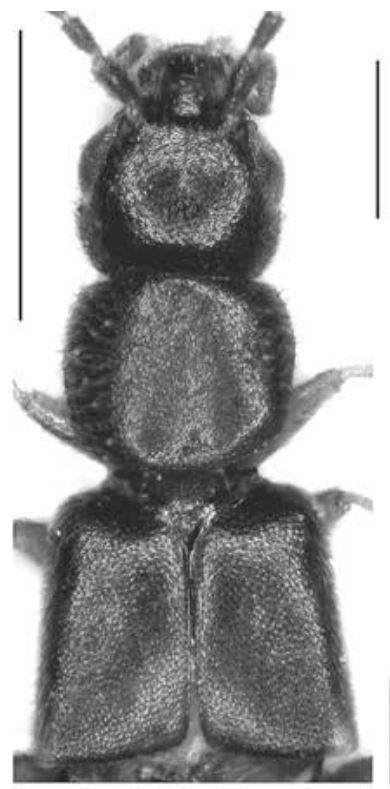

21

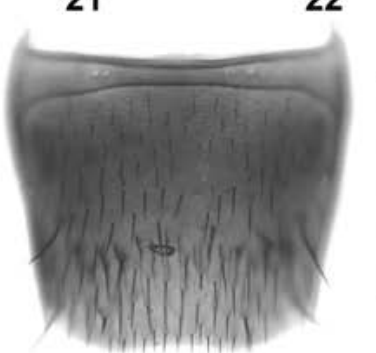

29

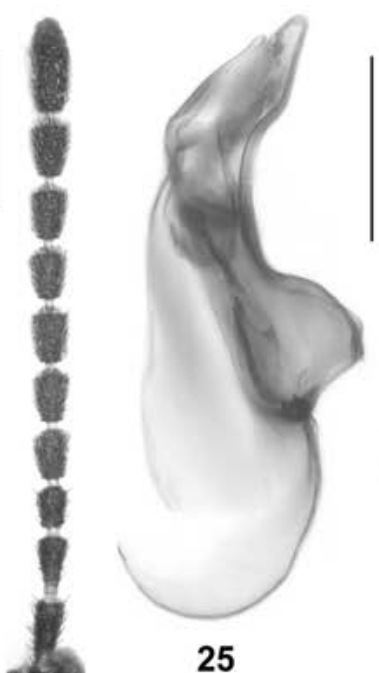

25

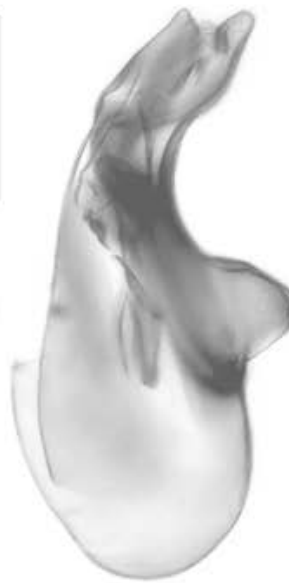

26

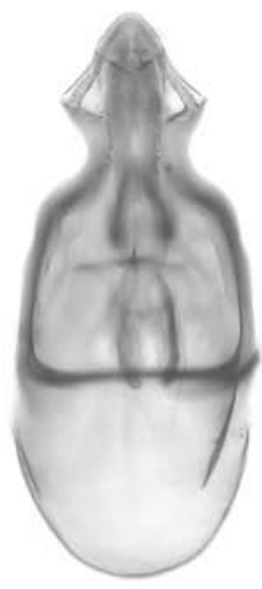

27

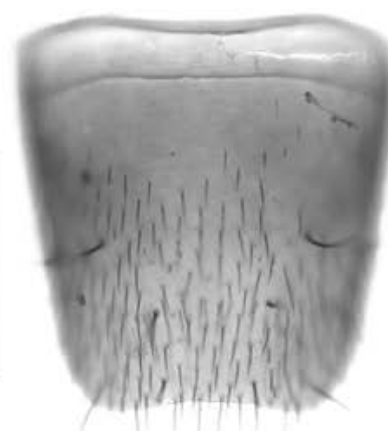

24

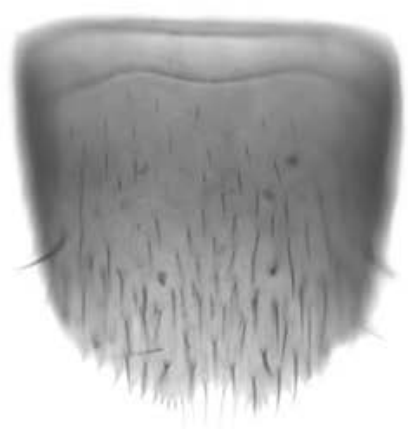

30

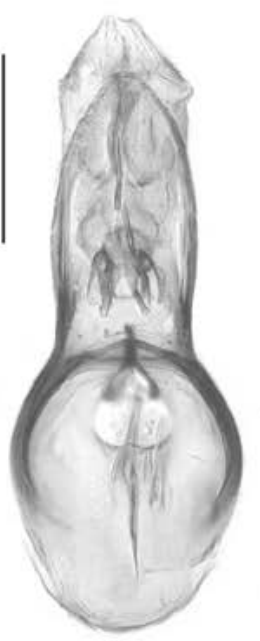

35

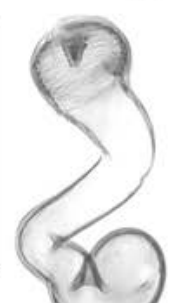

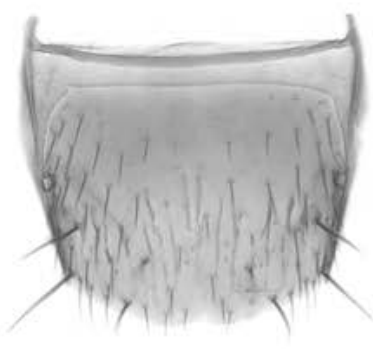

32

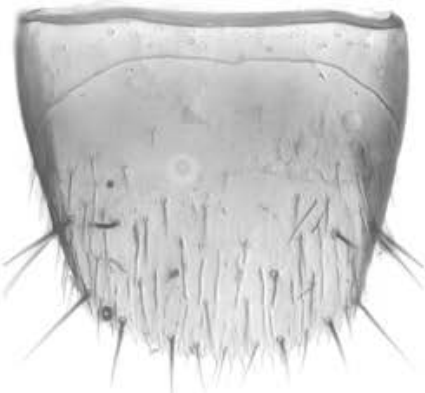

33

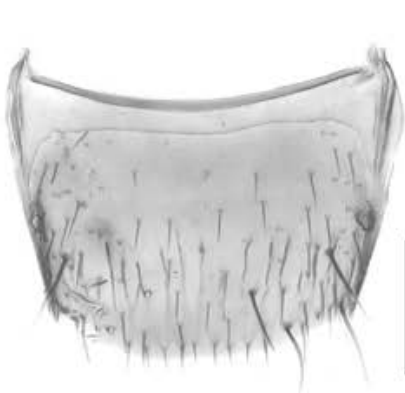

36

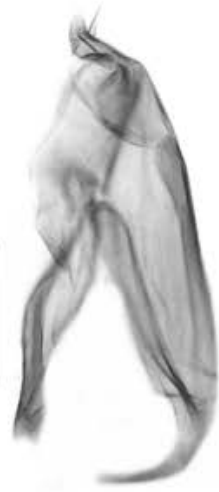

28

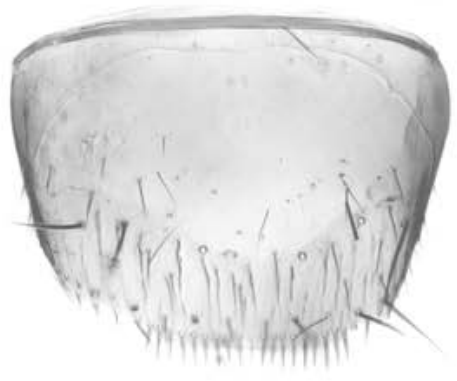

37

Figs 20-38: Hydrosmecta insularum (20-31) and Geostiba inexsecta (32-38): habitus (20); forebody (21); antenna (22); male tergite VIII $(23,32)$; male sternite VIII $(24,33)$; median lobe of aedeagus in lateral and in ventral view $(25-27,34-35)$; paramere (28); female tergite VIII $(29,36)$; female sternite VIII $(30,37)$; spermatheca $(31,38)$. Scale bars: 20: $1.0 \mathrm{~mm}$; $21: 0.5 \mathrm{~mm}$; 22-24, 29-30, 32-33, 36-37: $0.2 \mathrm{~mm} ; 25-28,31,34-35,38: 0.1 \mathrm{~mm}$. 


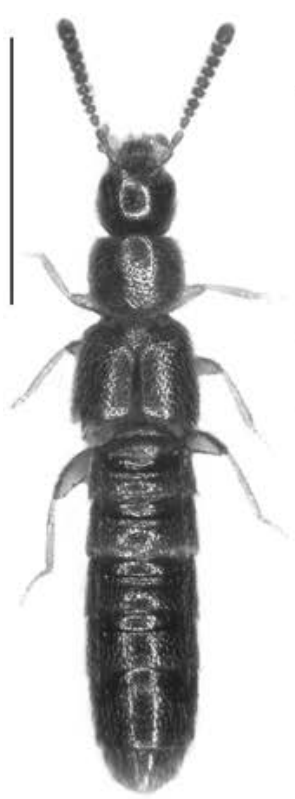

39

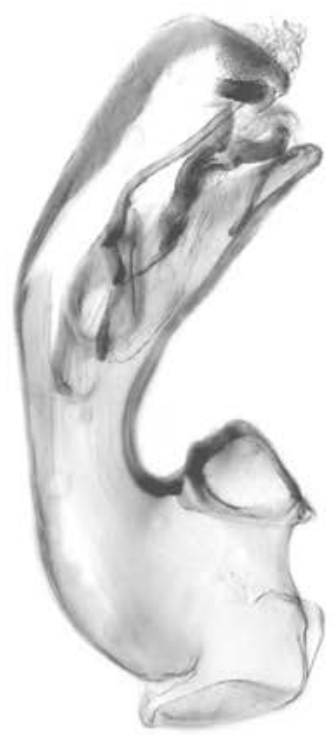

40

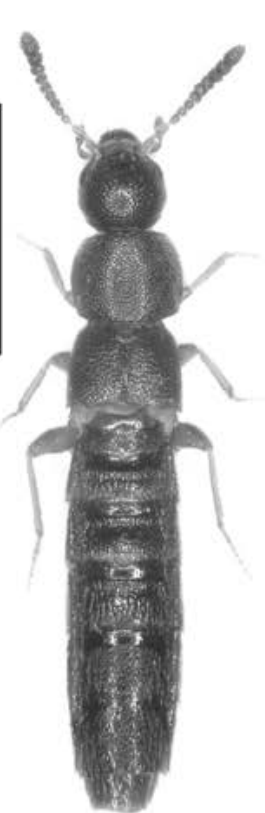

44

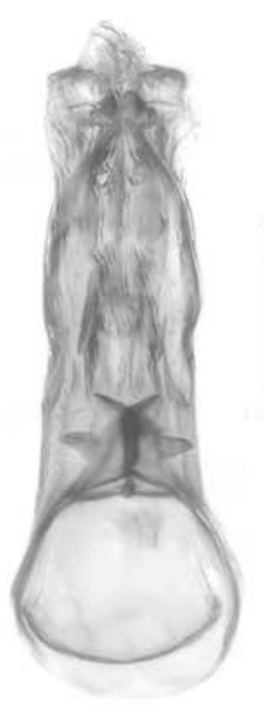

41

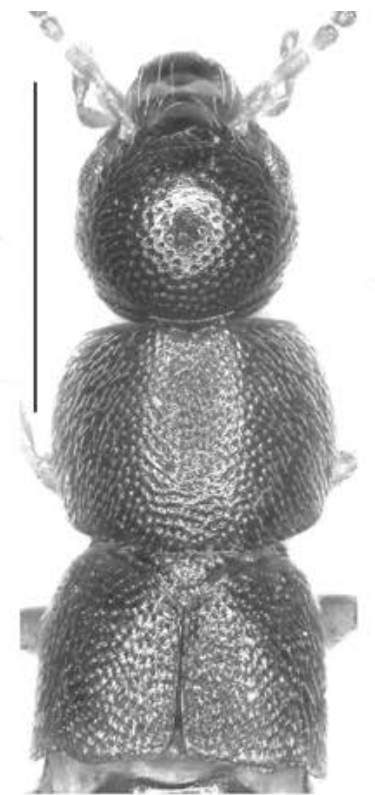

45

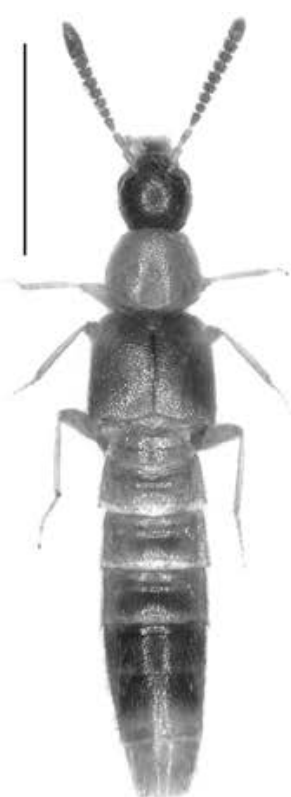

47

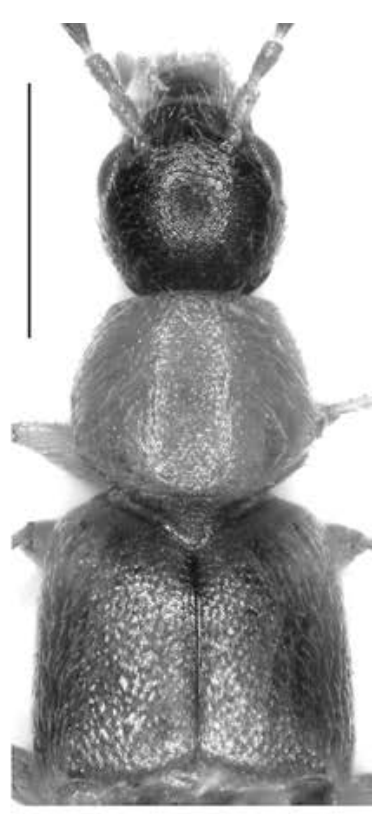

48

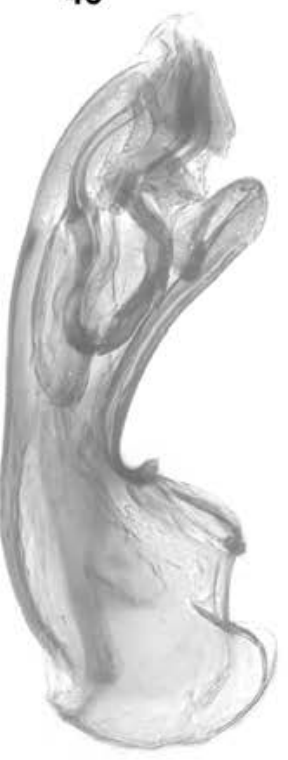

51

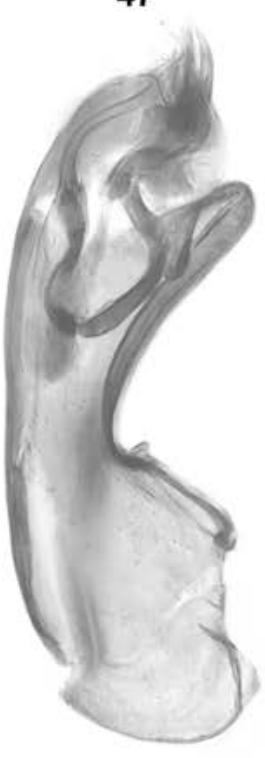

52

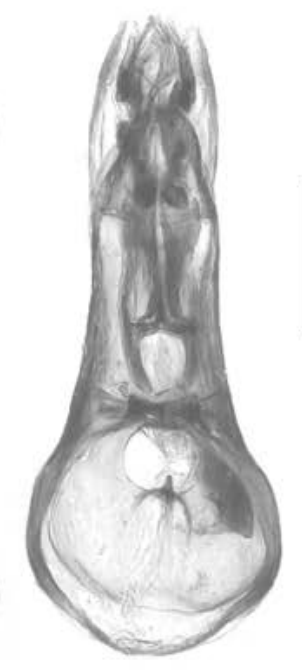

53

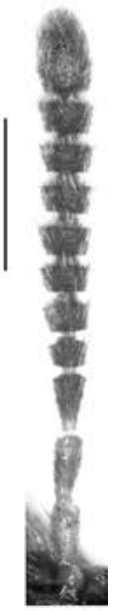

49
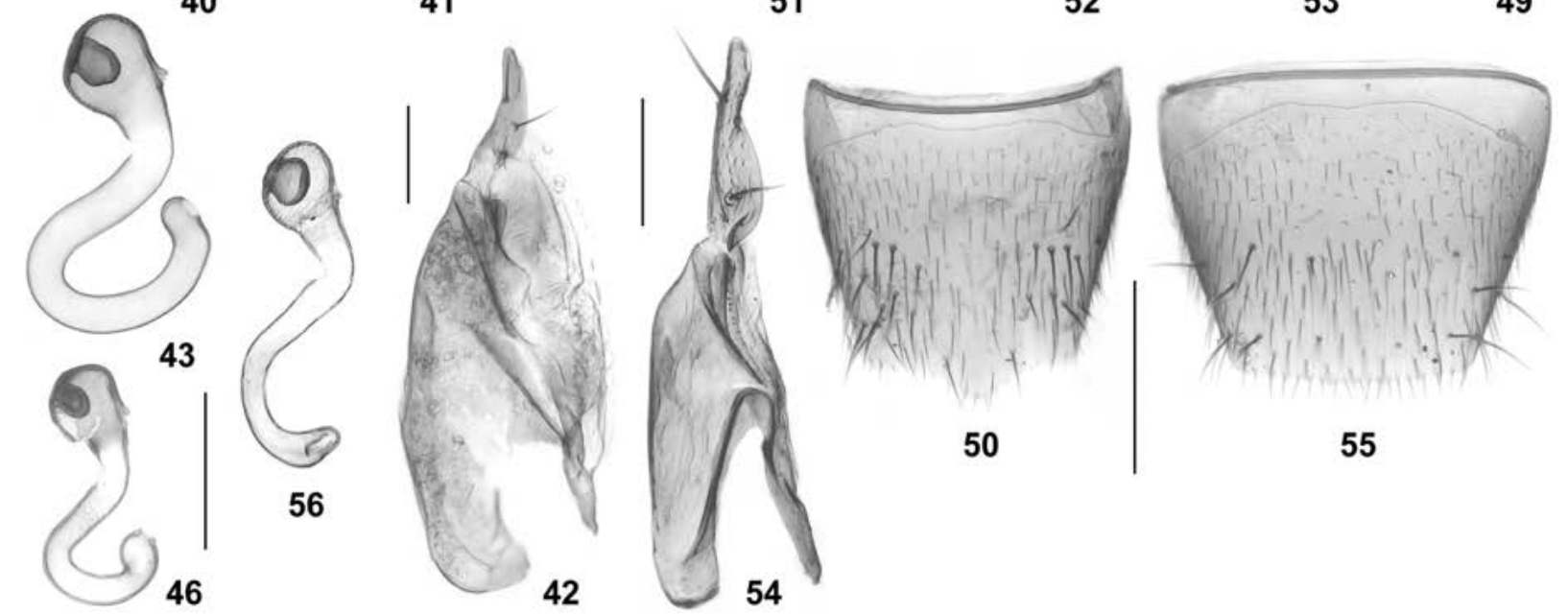

Figs 39-56: Cousya candica (39-43), Oxypoda bimontium (44-46), and O. retunsa (47-56): habitus (39, 44, 47); median lobe of aedeagus in lateral and in ventral view $(40-41,51-53)$; paramere $(42,54)$; spermatheca $(43,46,56)$; forebody $(45,48)$; antenna $(49)$; male sternite VIII (50); female sternite VIII (55). Scale bars: 39, 44, 47: $1.0 \mathrm{~mm}$; 45, 48: $0.5 \mathrm{~mm}$; 49-50, 55: 0.2 mm; 40-43, 46, 51-54, 56: $0.1 \mathrm{~mm}$. 

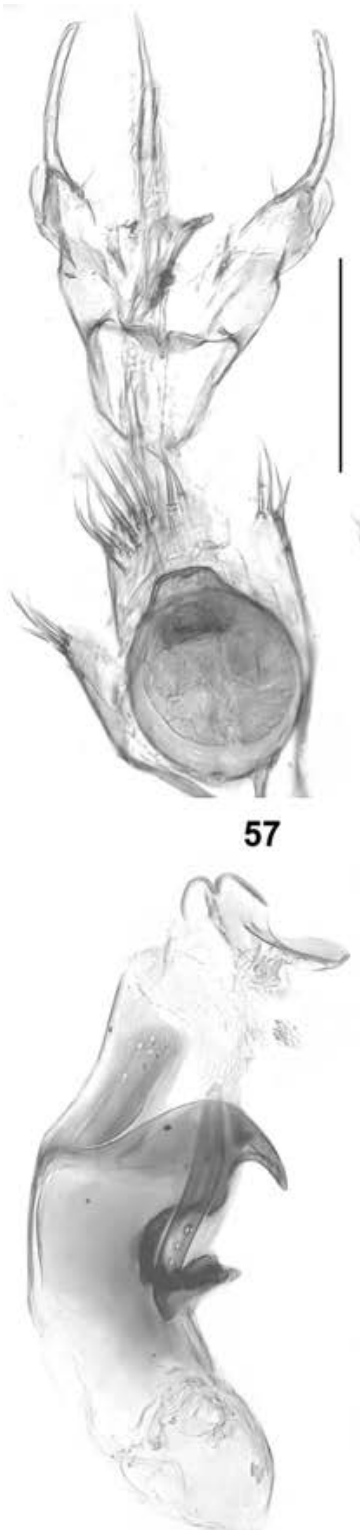

63

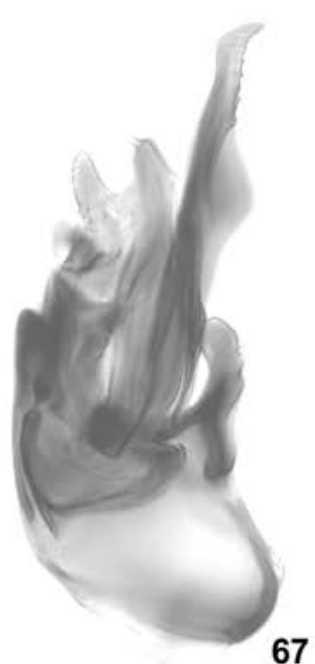

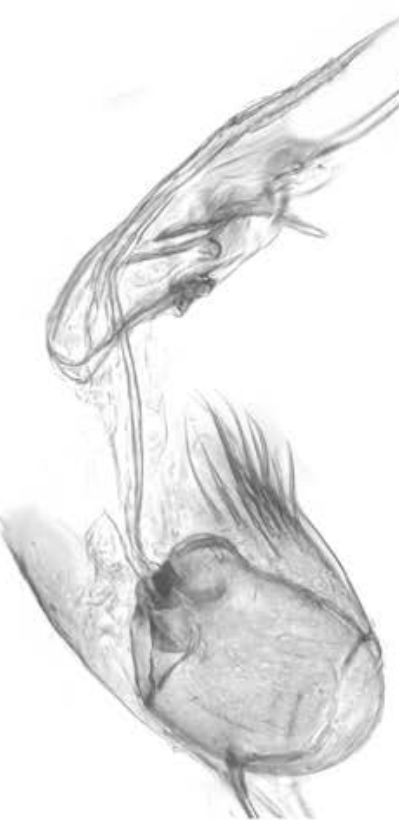

58

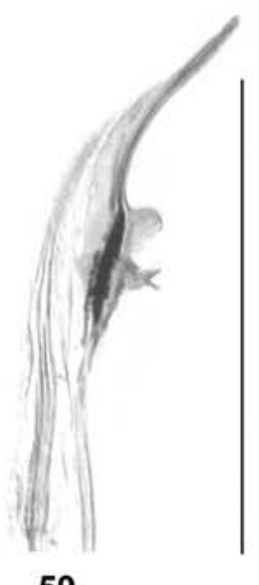

59

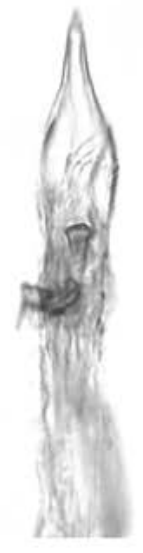

60

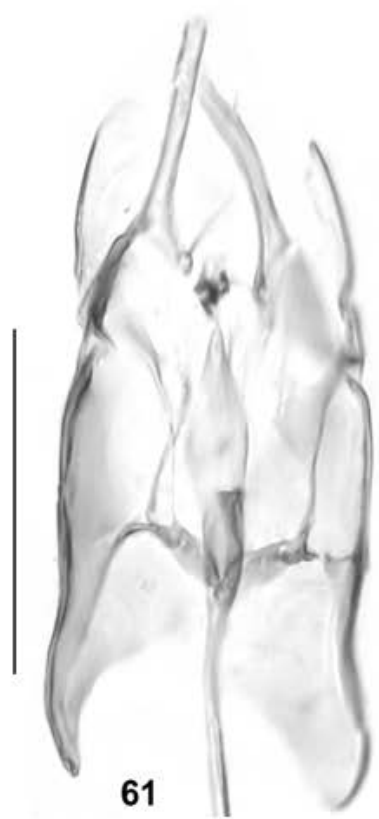

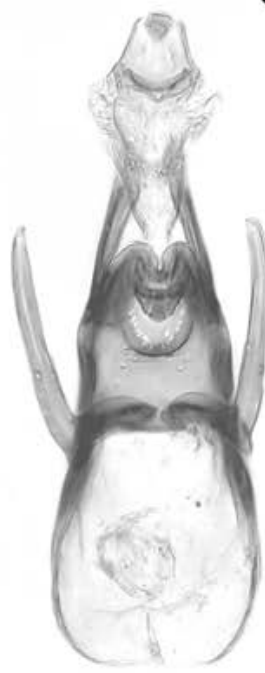

64

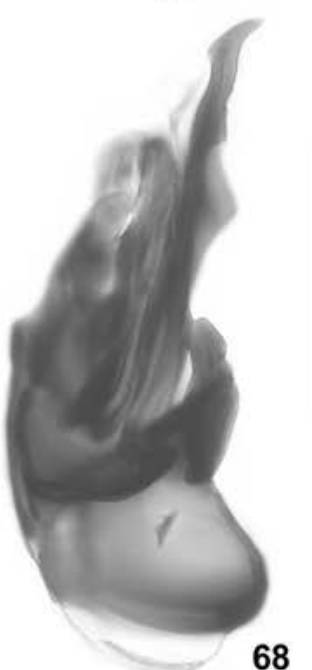

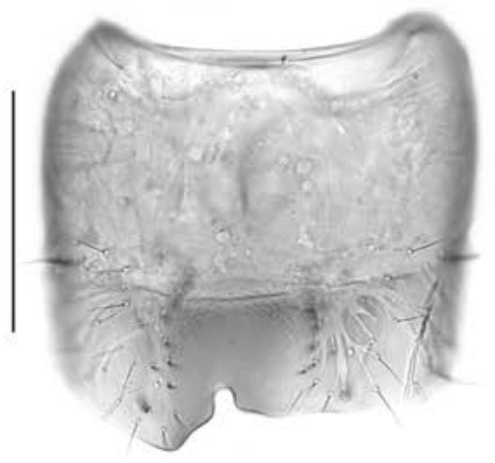

66

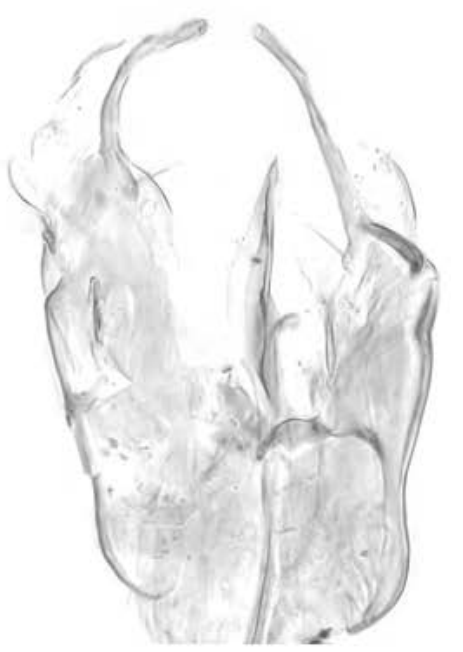

62
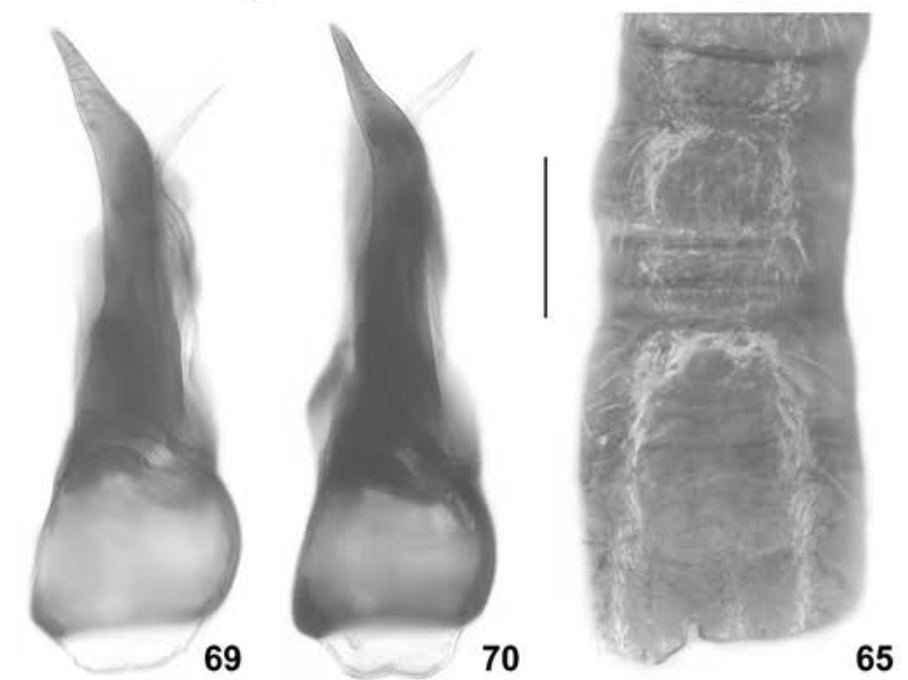

65

Figs 57-70: Typhlocyptus creticus (57-60), T. pandellei (61-62), Geomitopsis cretica (63-64), and Allotyphlus foedatus (65-70): aedeagus in lateral and in ventral view (57-58, 61-64, 67-70); ventral process of aedeagus in lateral and in ventral view (59-60); male sternites VI-VIII (65); male sternite VIII (66). Scale bars: $0.1 \mathrm{~mm}$. 


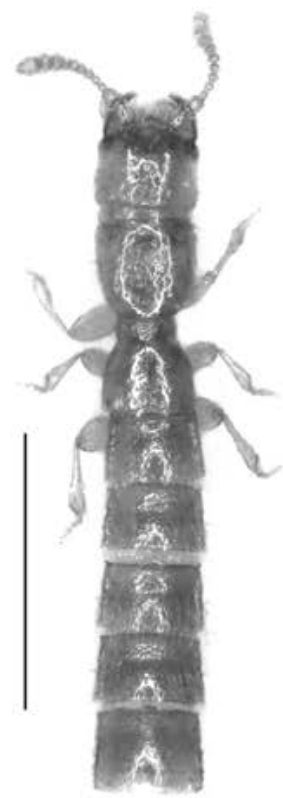

74

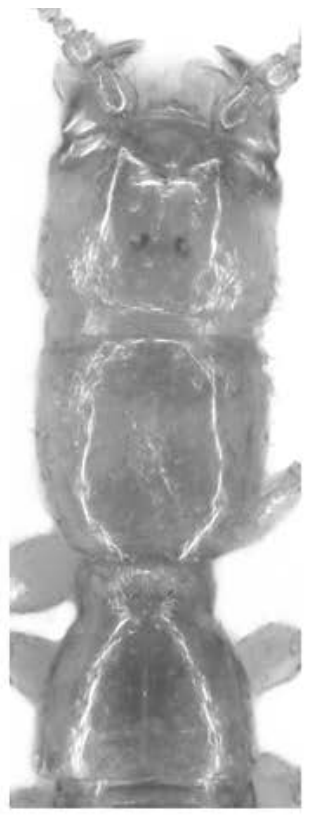

75

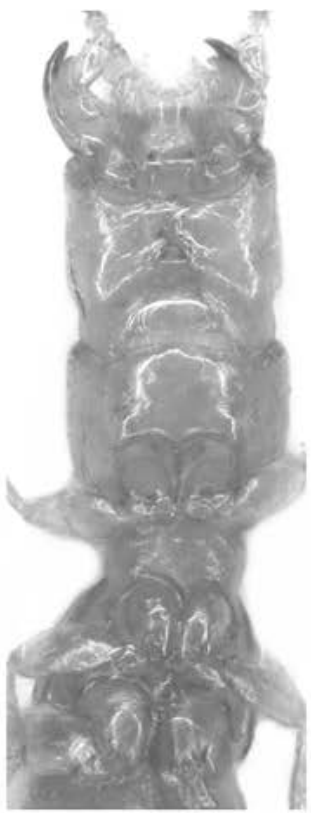

76

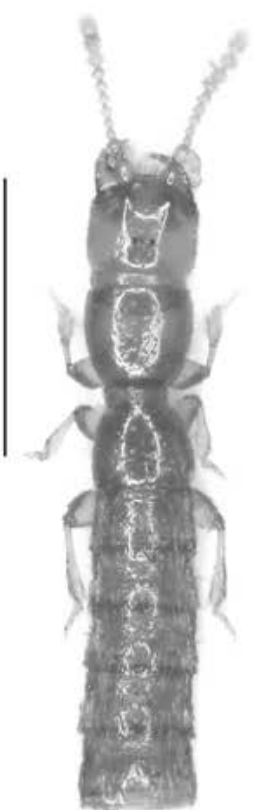

81

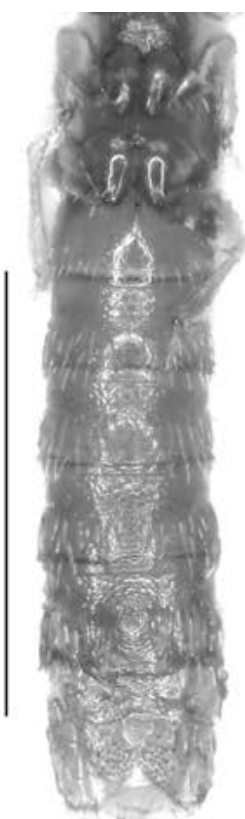

82

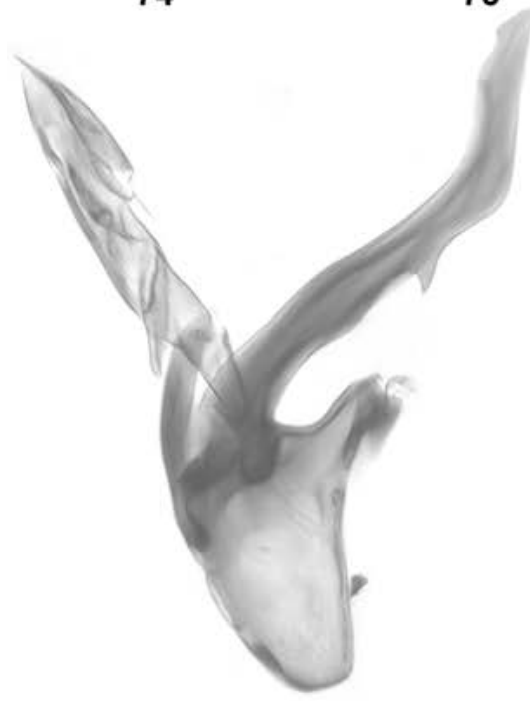

78

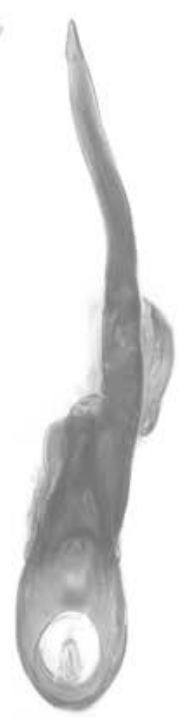

79

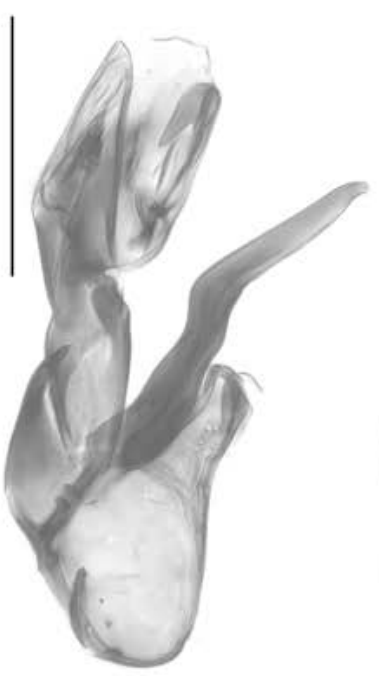

83

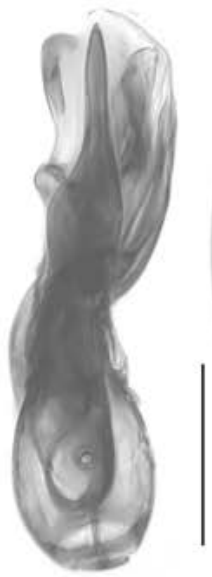

84

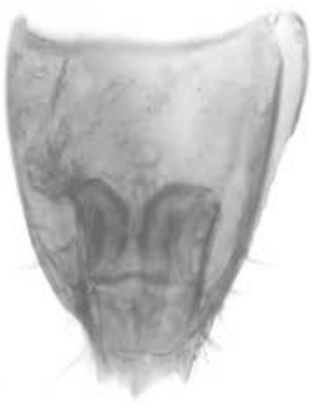

80
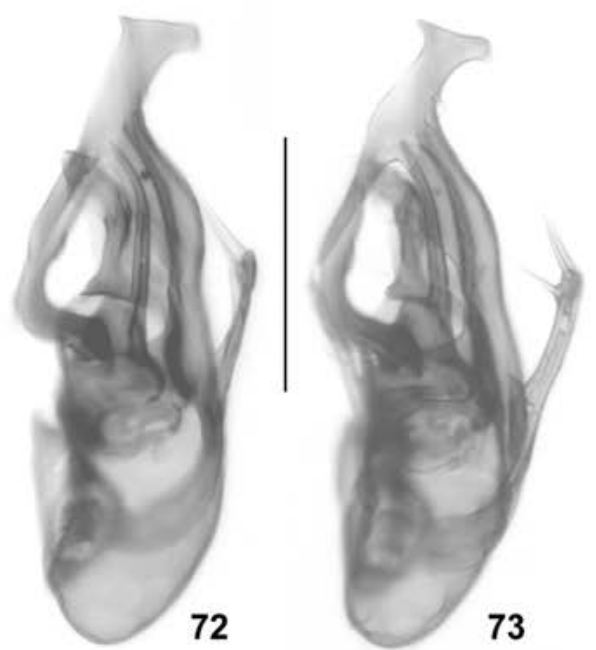

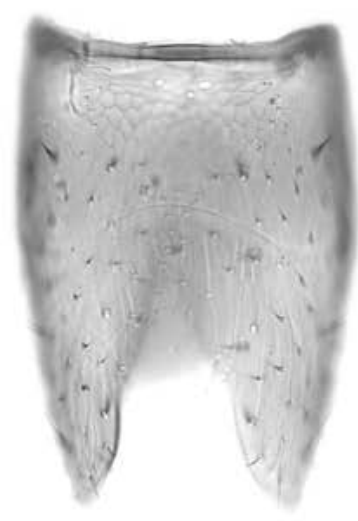

71

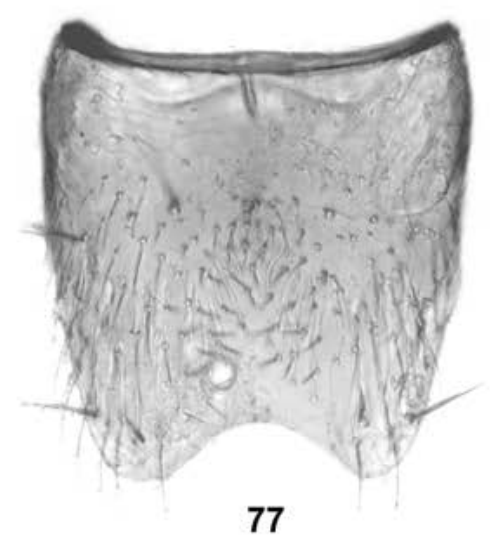

Figs 71-84: Kenotyphlus virgatus (71-73), Cretotyphlus hamatus (74-80), and C. idanus (81-84): male sternite VIII (71,77); aedeagus in lateral and in ventral, or in latero-ventral view $(72-73,78-79,83-84)$; habitus $(74,81)$; forebody in dorsal view (75); forebody in ventral view (76); female genital segment (80); male meso- and metathorax and abdomen in ventral view (82). Scale bars: 74, 81-82: $0.5 \mathrm{~mm} ; 71-73,75-80,83-84: 0.1 \mathrm{~mm}$. 


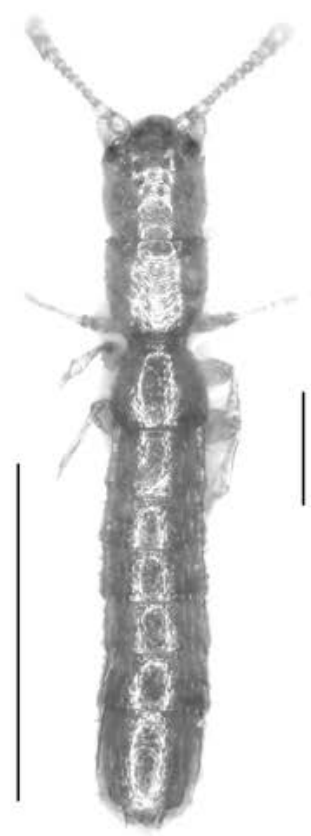

86

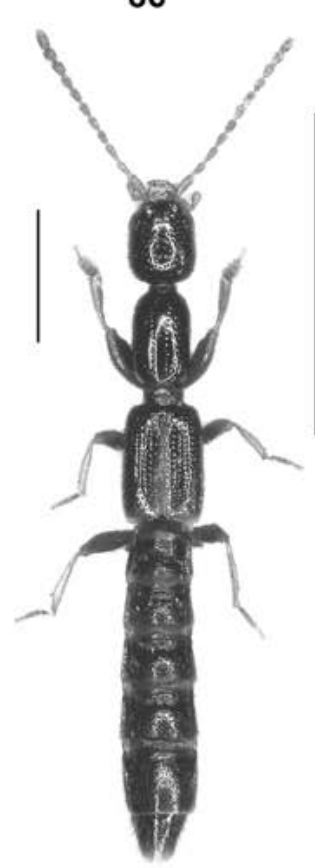

92

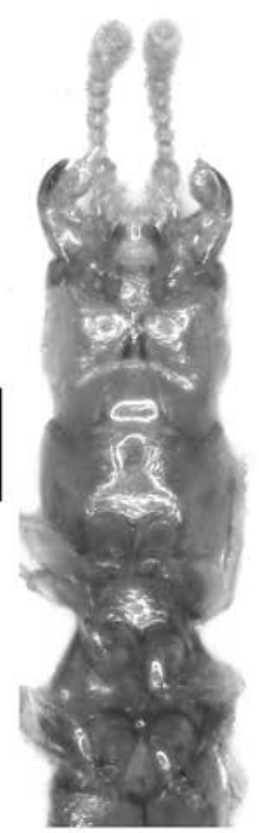

87

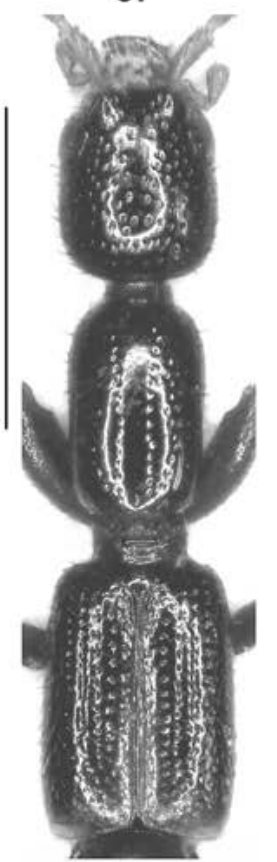

93

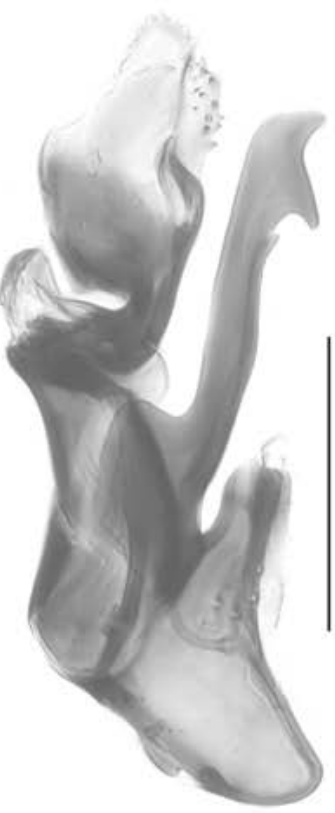

89
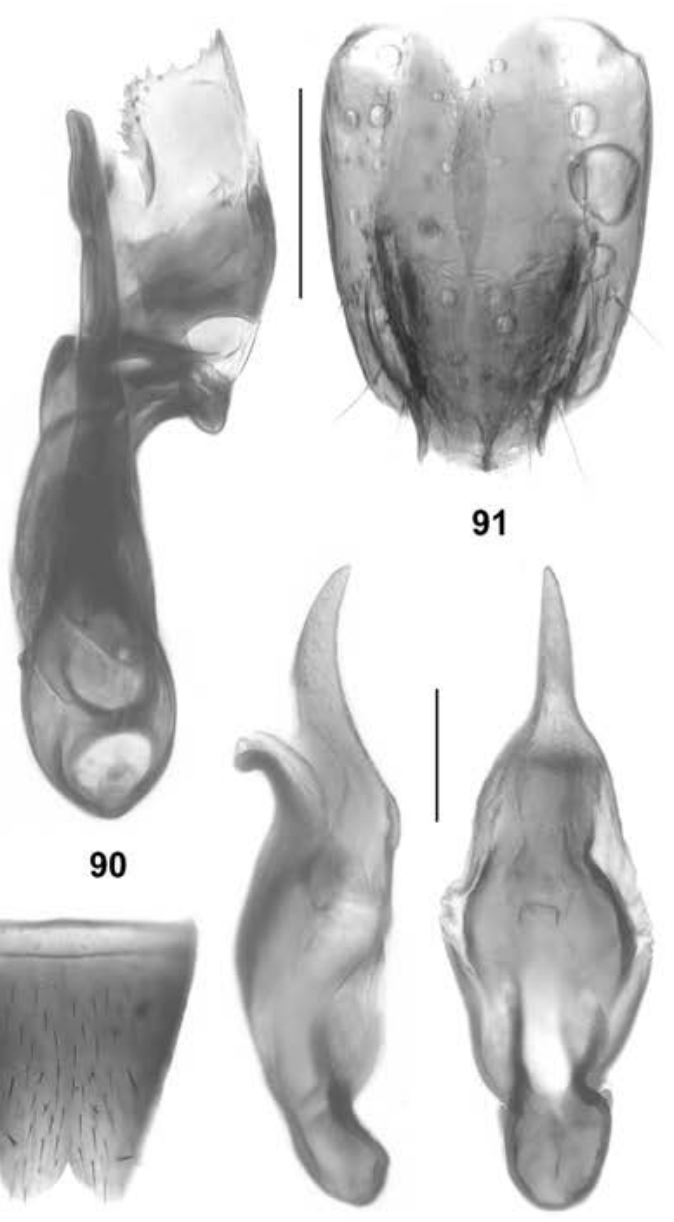

95

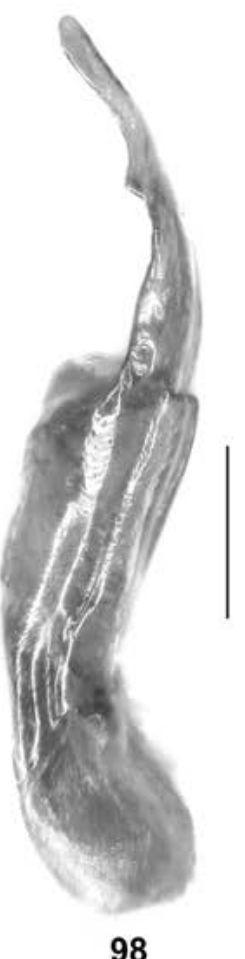

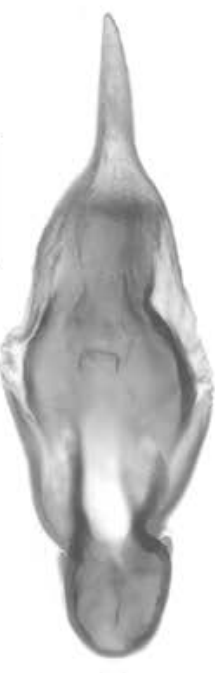

96
88

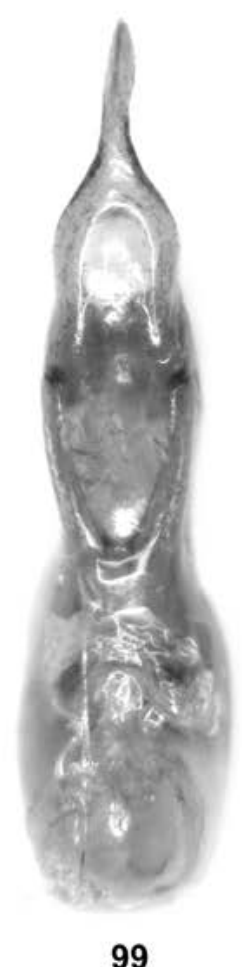

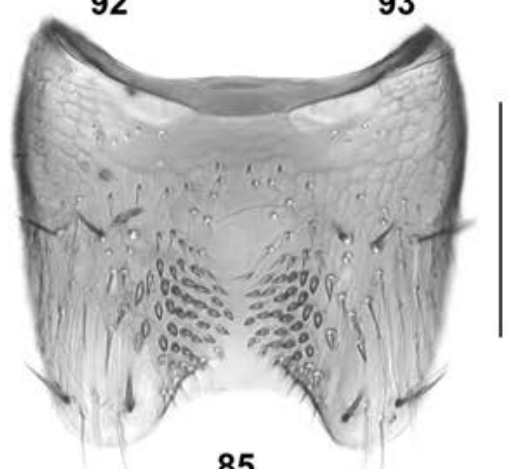

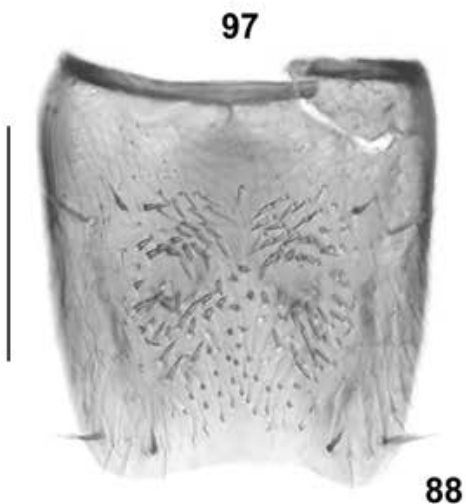

Figs 85-99: Cretotyphlus idanus (85), C. chanianus (86-91), Pseudobium creticum (92-96), and Gabrius candicus (97-99): male sternite VIII $(85,88,94)$; habitus $(86,92,97)$; forebody in ventral view $(87)$; aedeagus in lateral and in ventral view $(89-90,95-96$, 98-99); female genital segments (91); forebody (93). Scale bars: 92-93, 97: $1.0 \mathrm{~mm}$; 86: 0.5 mm; 98-99: 0.2 mm; 85, 87-91, 94-96: $0.1 \mathrm{~mm}$. 

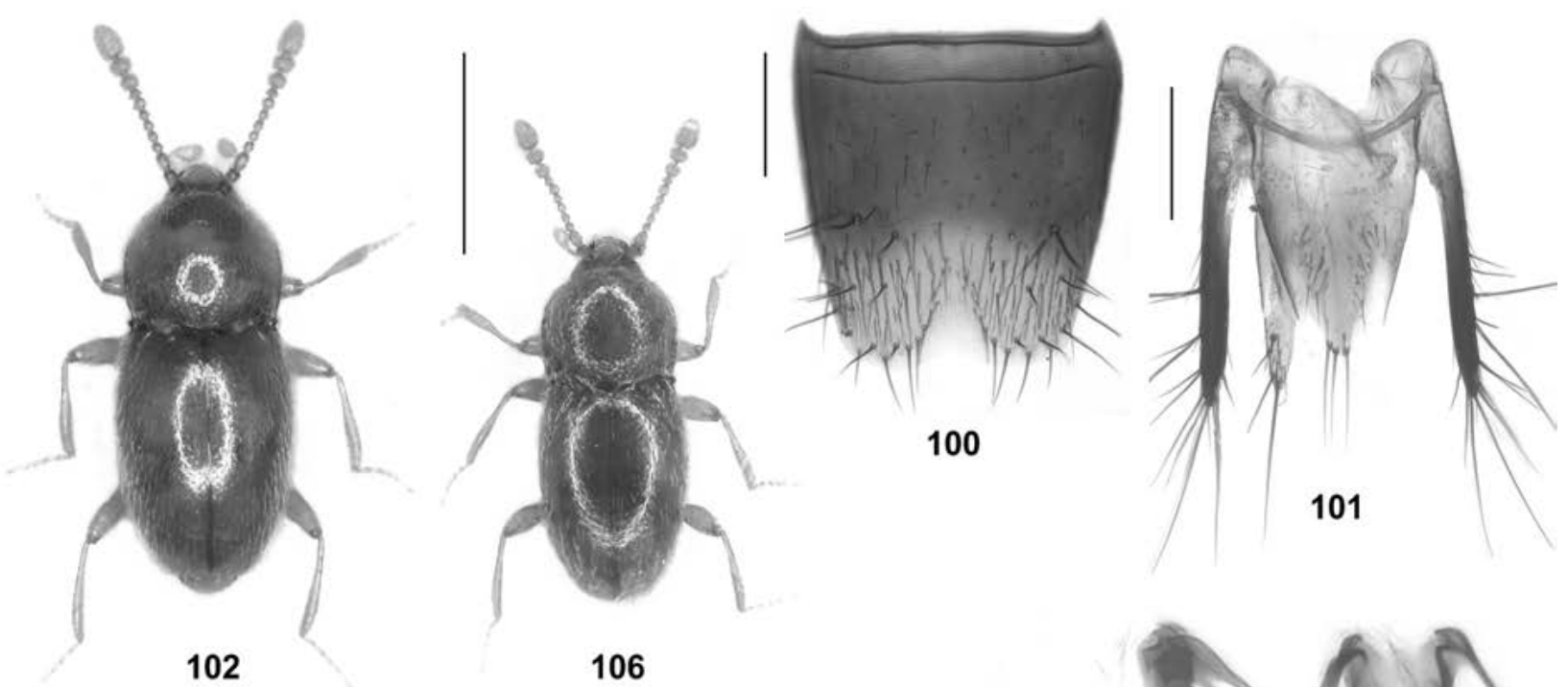

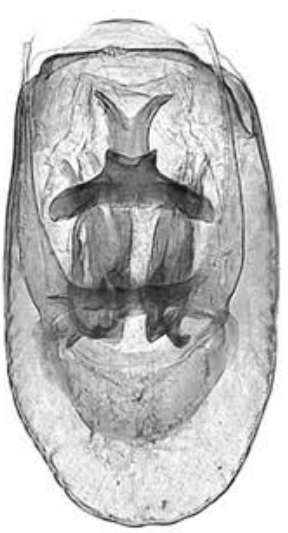

103

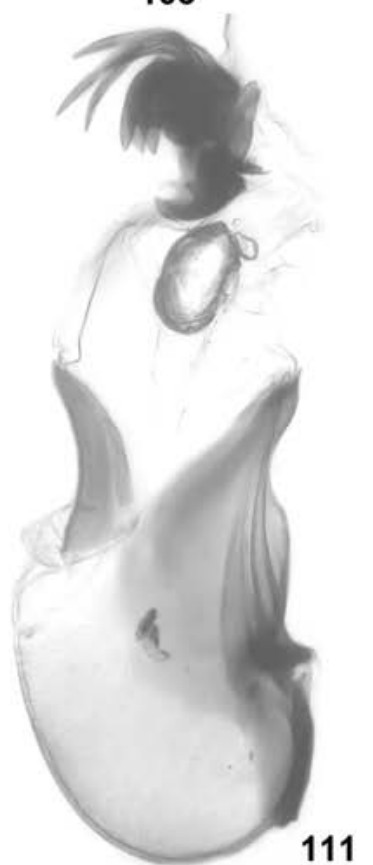

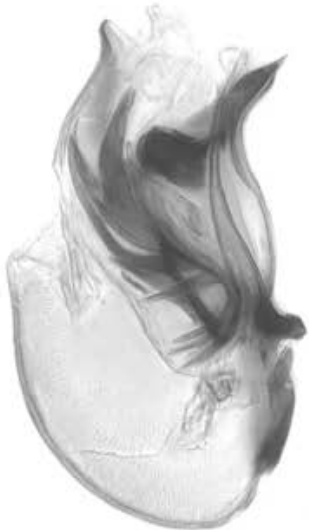

109

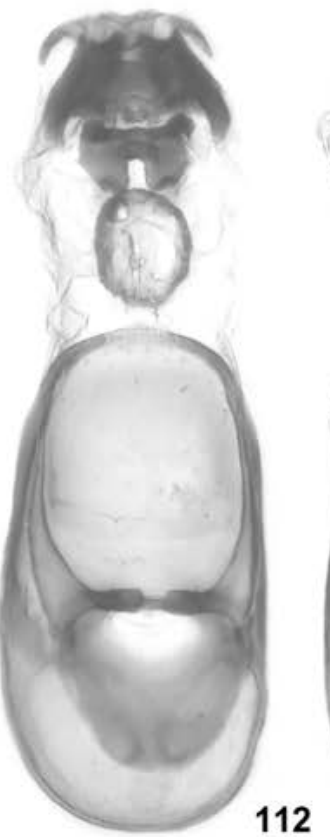

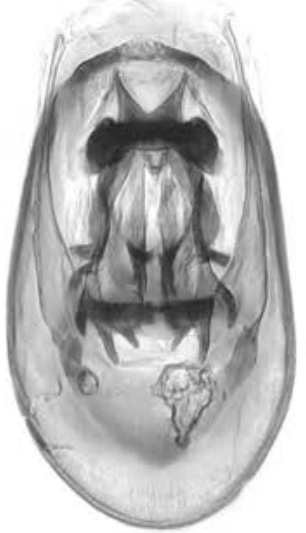

110
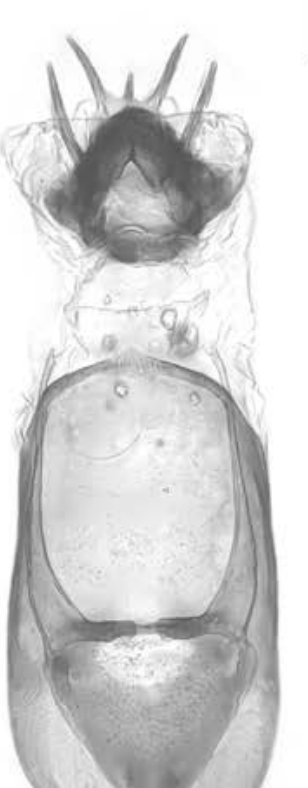

12

Figs 100-113: Gabrius candicus (100-101) and Cephennium spp. of the C. arcuatum group: C. arcuatum (102-103), C. thripticum (104-105), C. selinonum (106-108), C. meybohmi (109-110), and C. idanum (111-113): male sternite VIII (100); female abdominal segments IX-X (101); habitus $(102,106)$; aedeagus in lateral and in ventral view (103-105, 107-113). Scale bars: 102, 106: 0.5 mm; 100-101: $0.2 \mathrm{~mm}$; 103-105, 107-113: $0.1 \mathrm{~mm}$. 

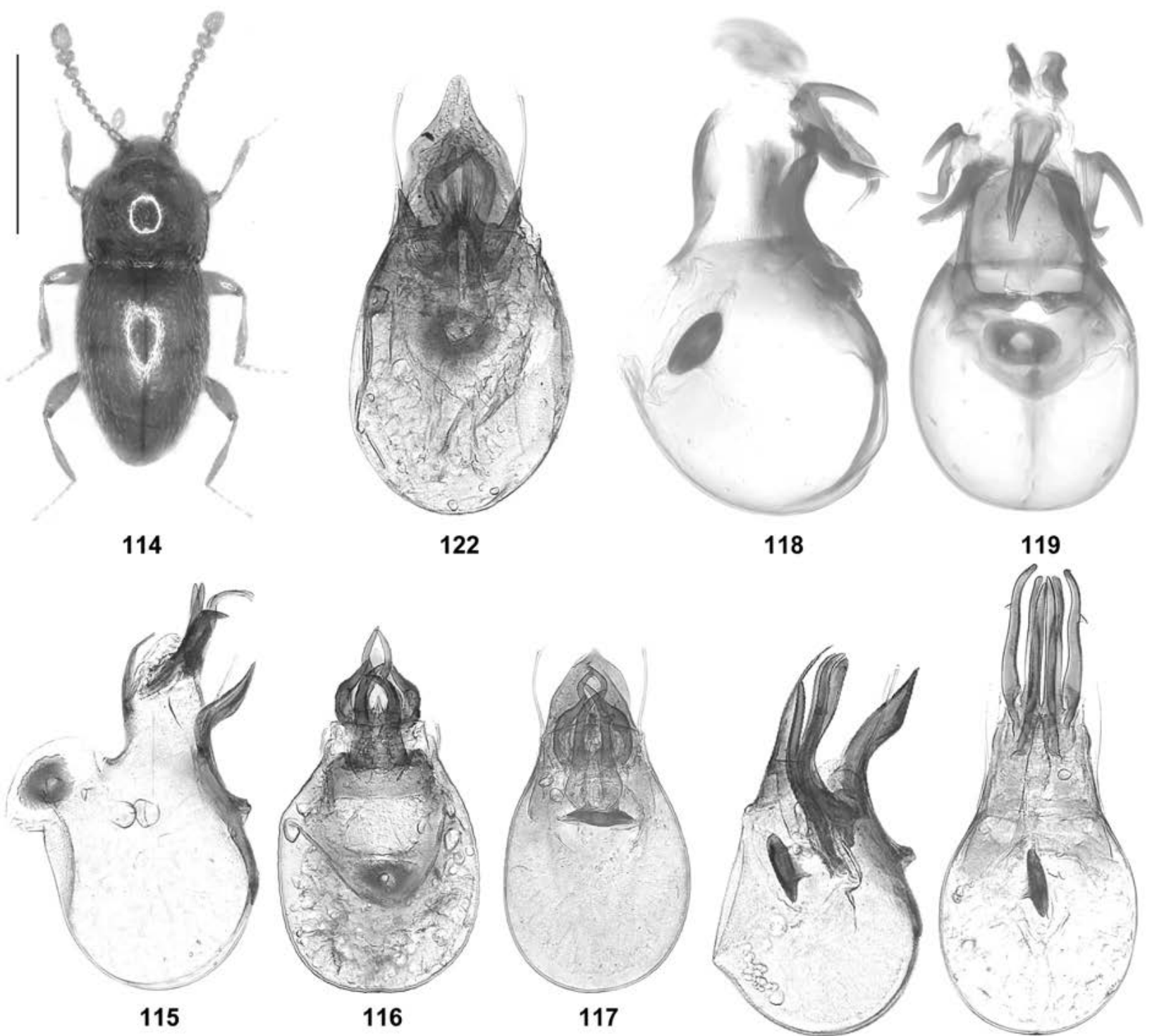

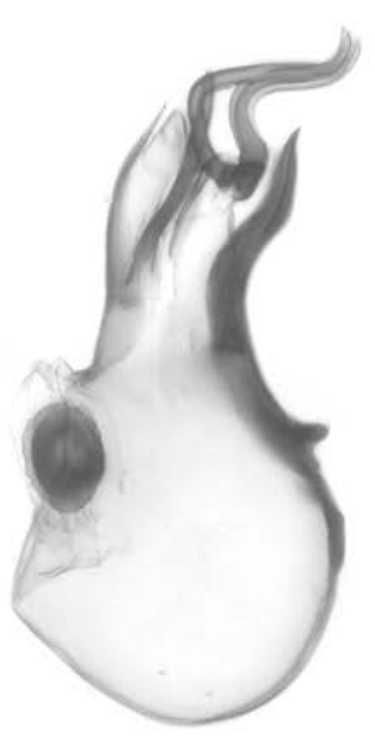

123

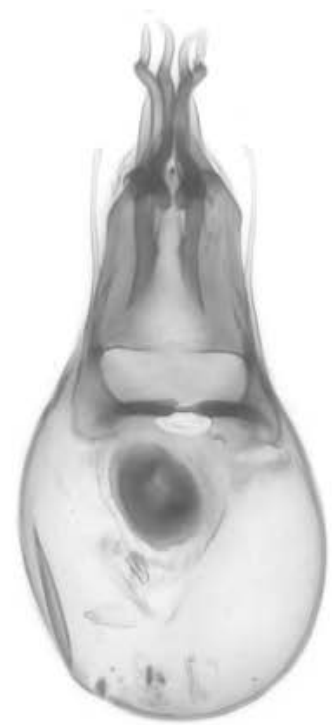

124

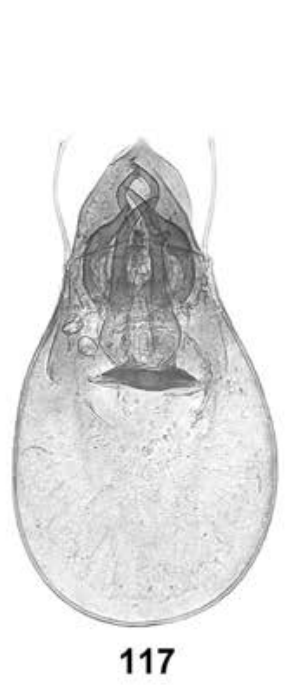

117

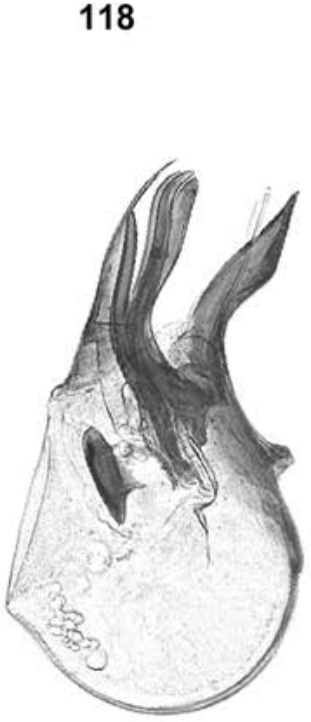

120
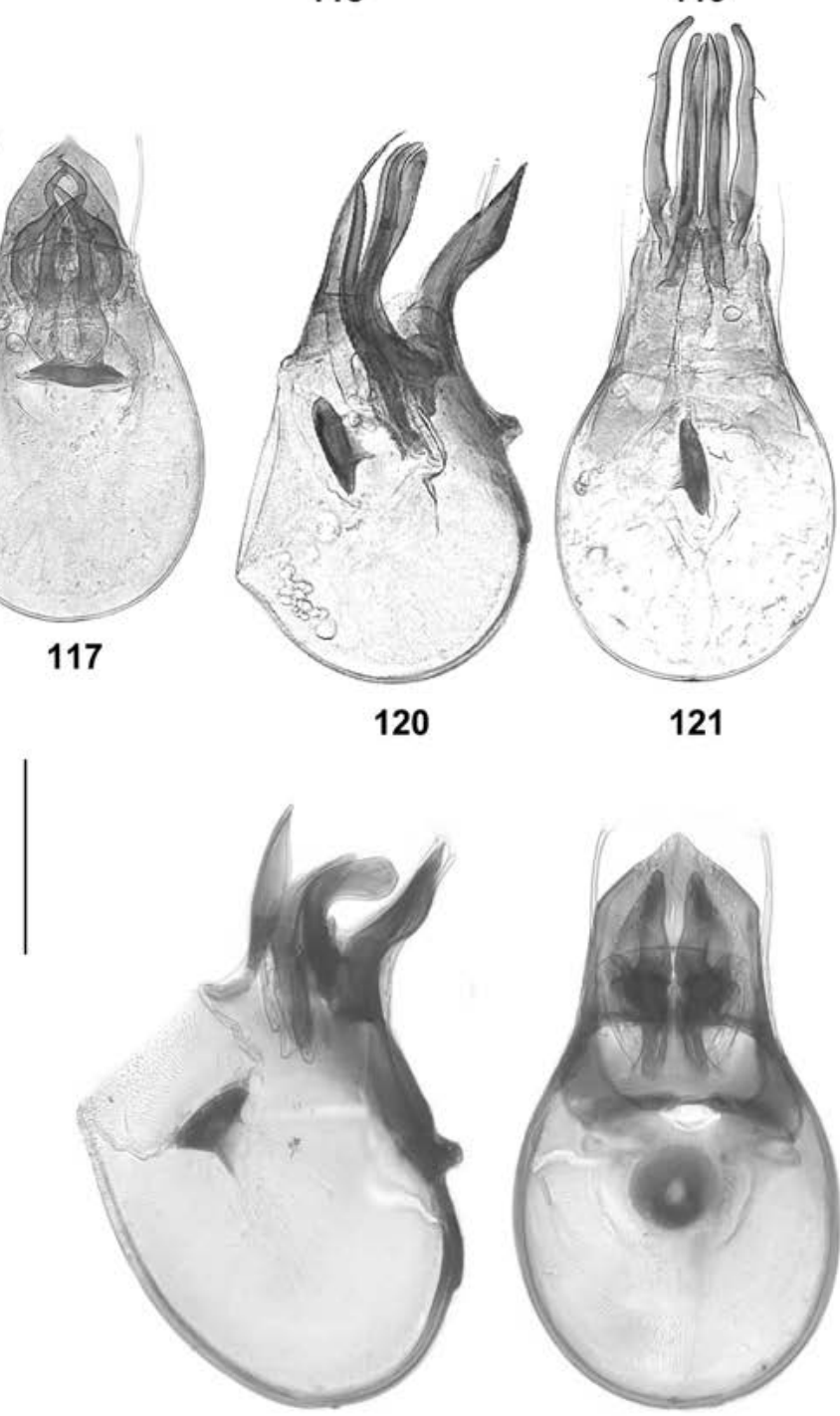

125

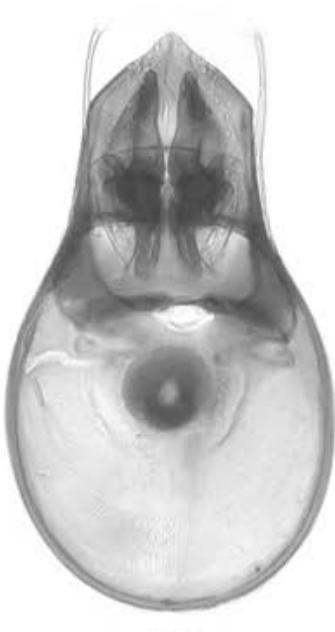

126

Figs 114-126: Cephennium spp. of the C. sinuosum group: C. sinuosum (114-117), C. fortespinosum (118-119), C. hamulatum (120121), C. curvatum (122), C. selenanum (123-124), and C. latius (125-126): habitus (114); aedeagus in lateral and in ventral view (115-126). Scale bars: 114: $0.5 \mathrm{~mm} ; 115-126: 0.1 \mathrm{~mm}$. 


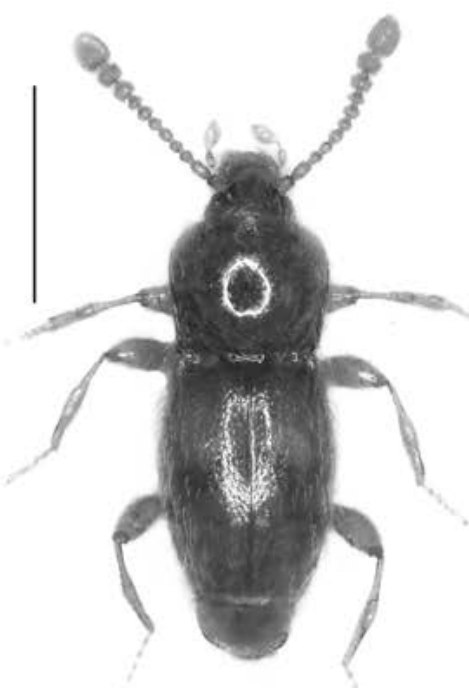

127

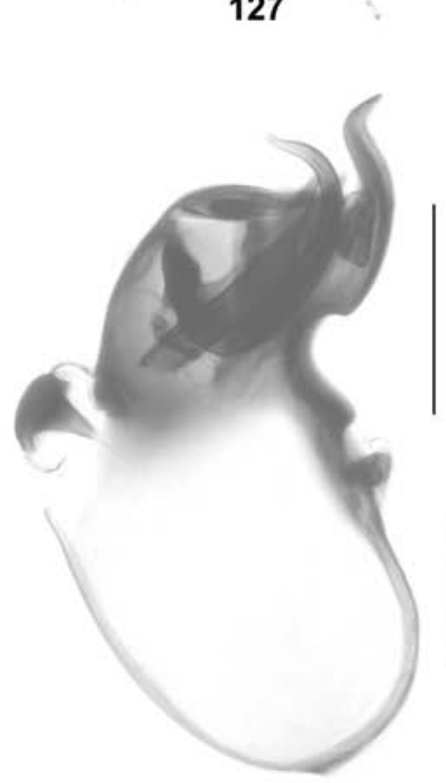

128

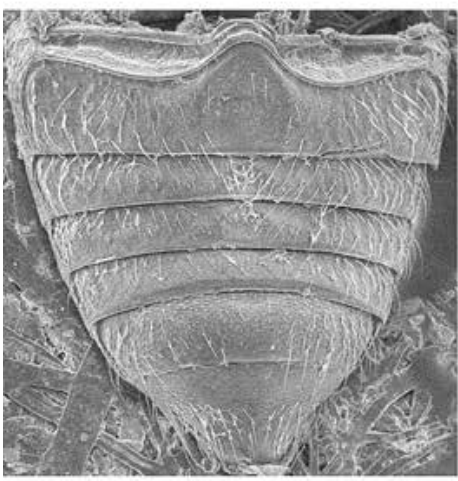

131
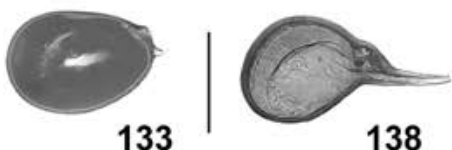

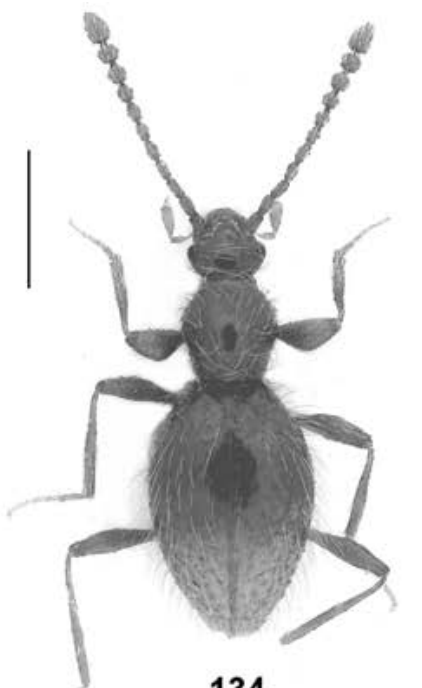

134
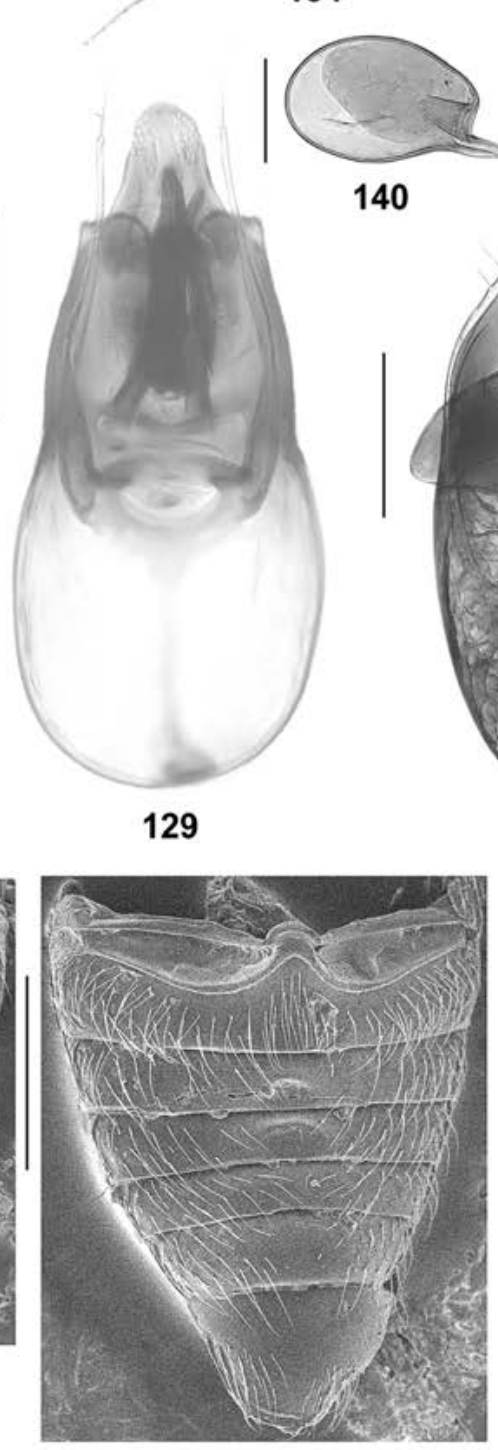

135

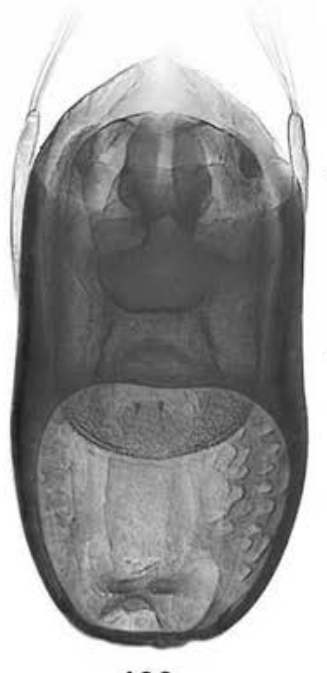

139

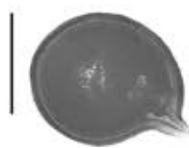

142

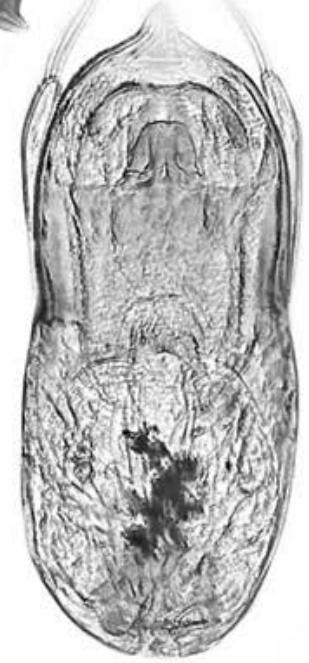

137

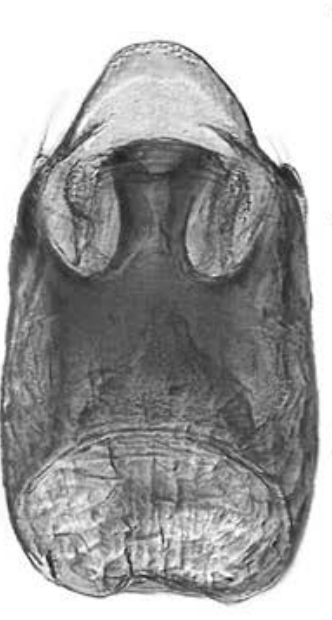

132

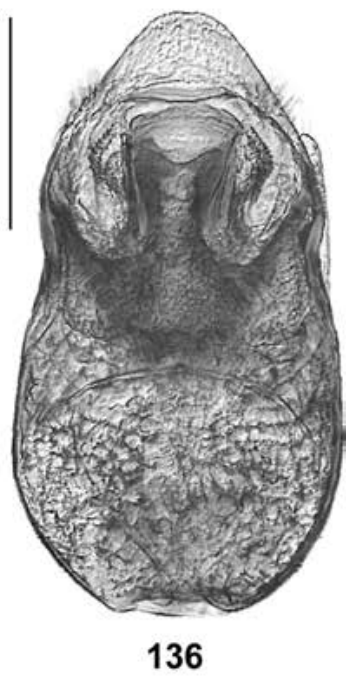

136

Figs 127-142: Cephennium chanianum (127-129), Euconnus zakrius (130), Stenichnus brachati (131-133), S. orientalis (134-136), S. aegialioides (137-138), S. aegialius (139-140), and S. godarti (141-142): habitus (127, 134); aedeagus in lateral, ventral, and dorsal view $(128-130,132,136-137,139,141)$; male abdomen in ventral view $(131,135)$; spermatheca $(133,138,140,142)$. Scale bars: 127, 134: $0.5 \mathrm{~mm}$; 131, 135: $0.2 \mathrm{~mm}$; 128-130, 132-133, 136-142: $0.1 \mathrm{~mm}$. 


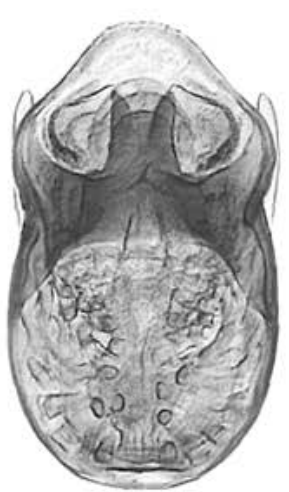

143

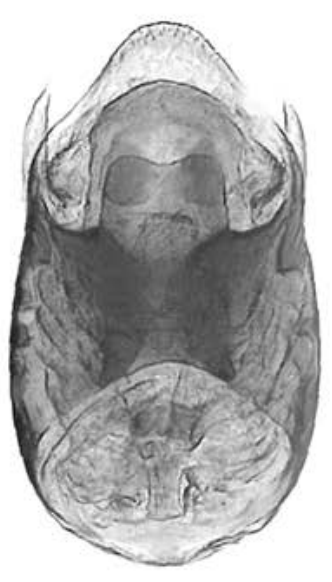

144

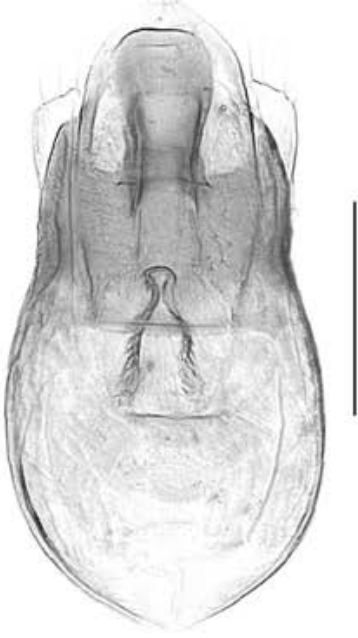

145

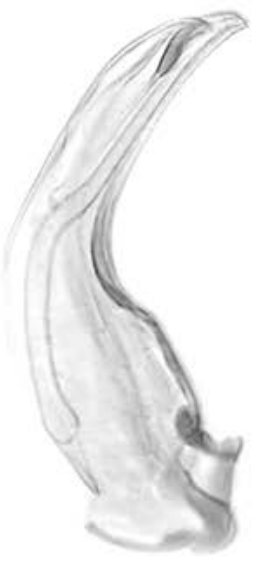

148

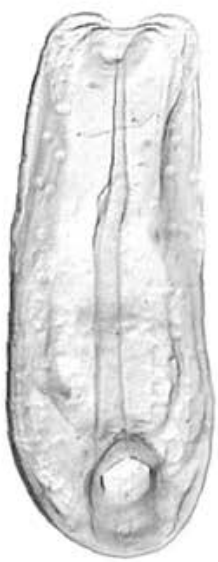

149

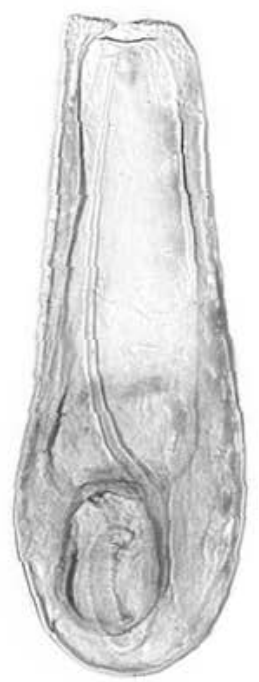

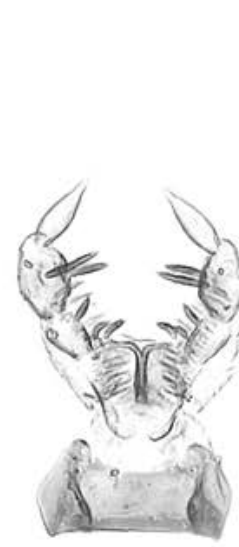

147

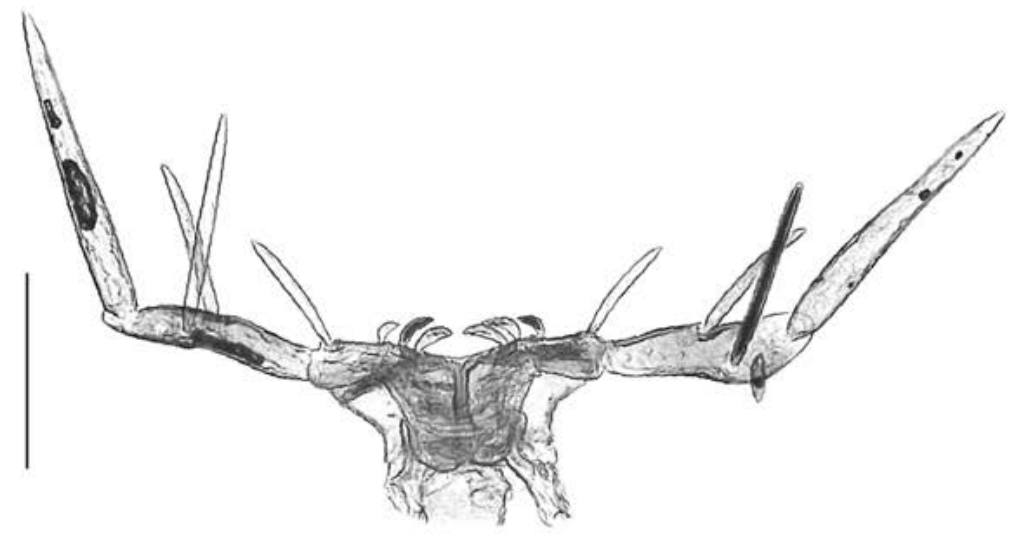

151

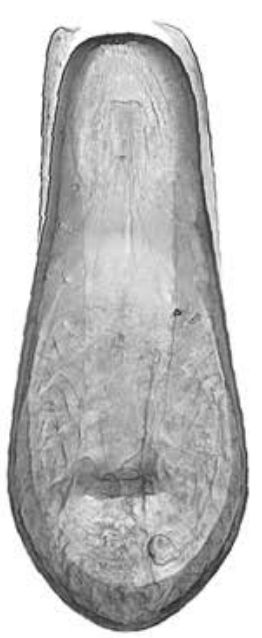

152

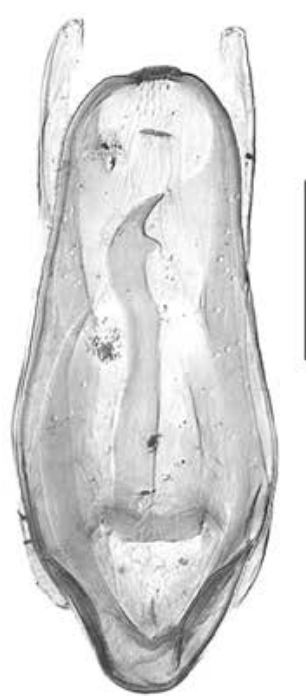

153

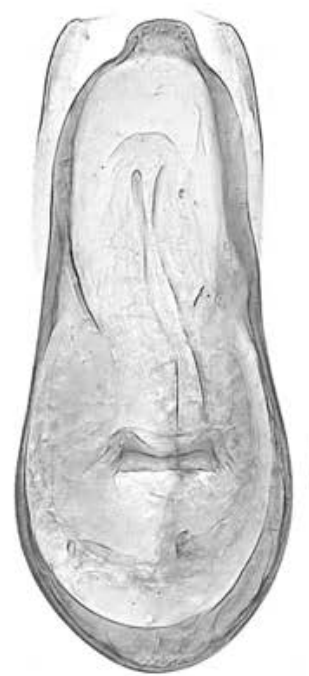

154

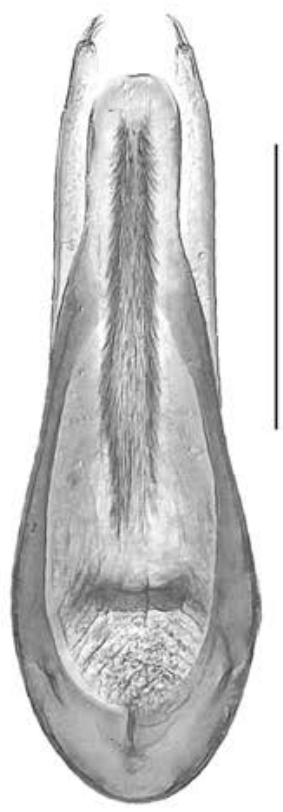

155

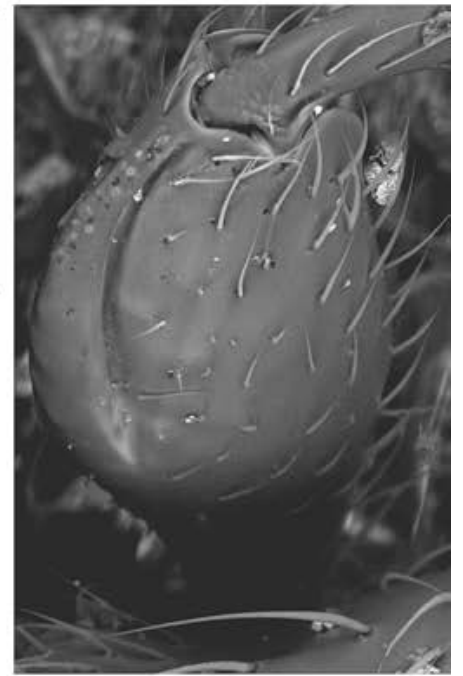

146

Figs 143-155: Stenichnus creticus (143), S. hummleri (144), S. basimpressus (145), S. aegialioides (146), Leptomastax cretica (147-149), L. thriptica (150), L. bisetosa (151), Afropselaphus doernfeldae (152), A. assingi (153), A. diktianus (154), and A. thripticus (155): aedeagus in lateral and dorsal view (143-145, 148-150, 152-155); male profemur (146); labium (147, 151). Scale bars: $0.1 \mathrm{~mm}$. 

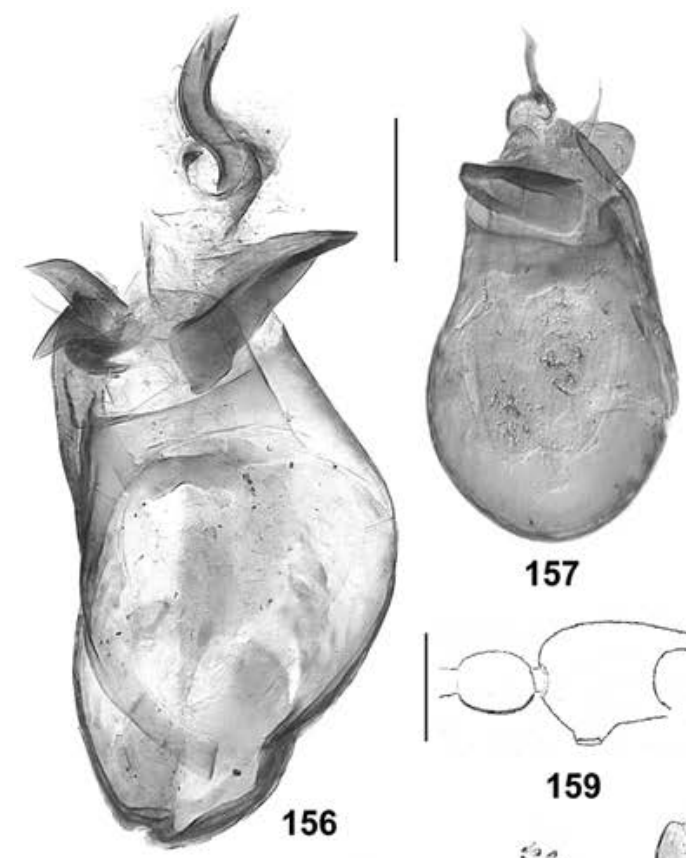

157

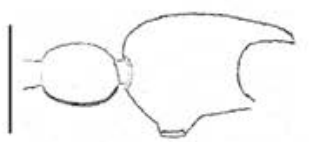

159
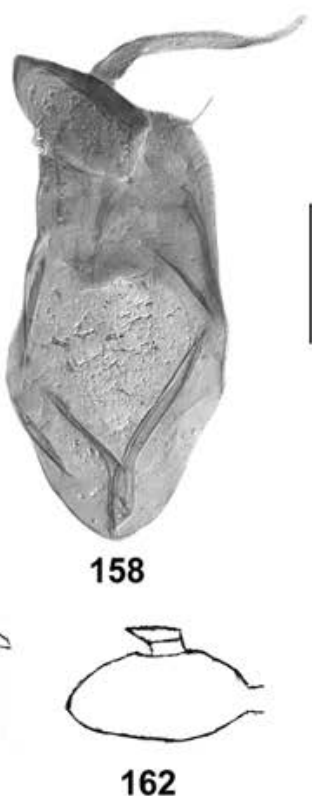

162
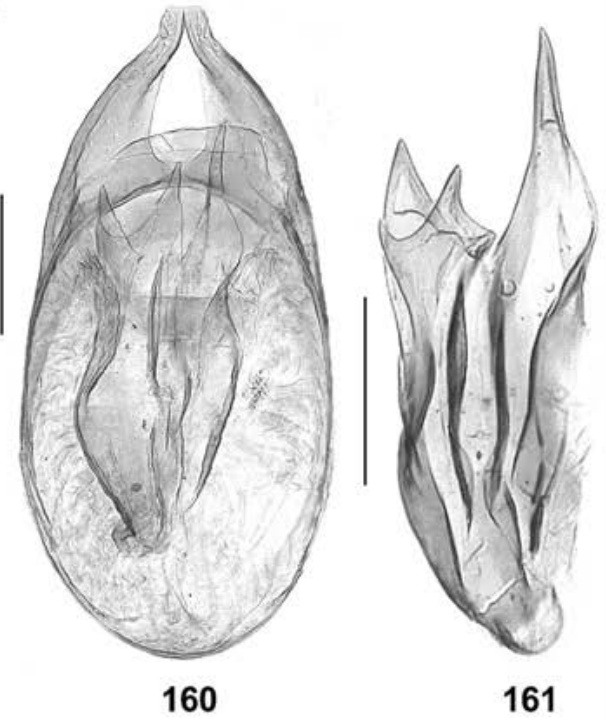

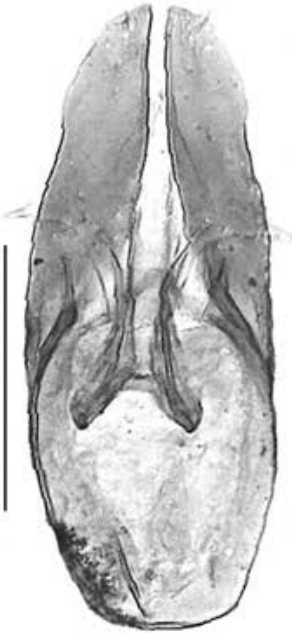

163

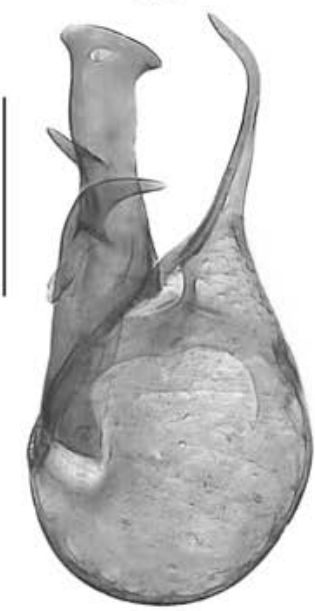

168

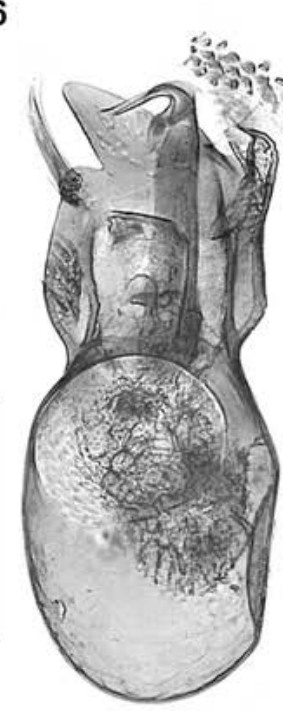

164

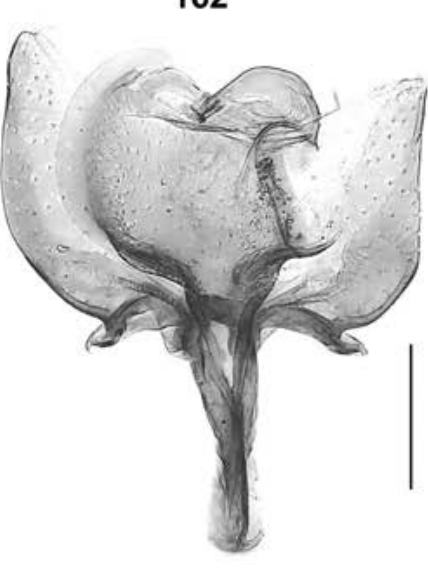

165
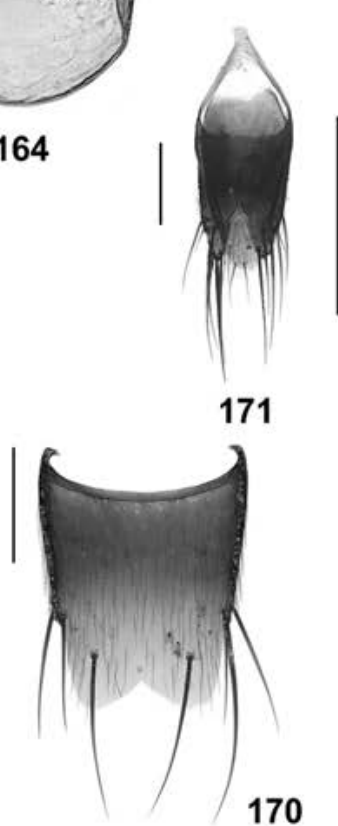

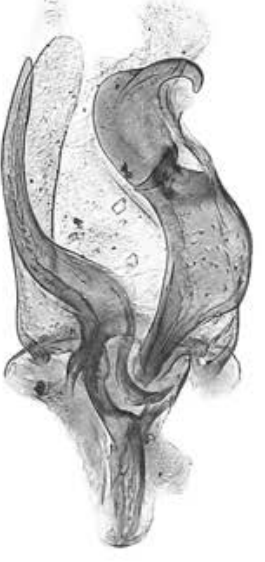

166

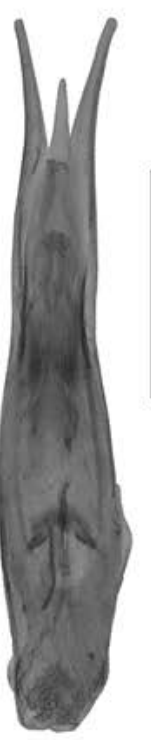

172
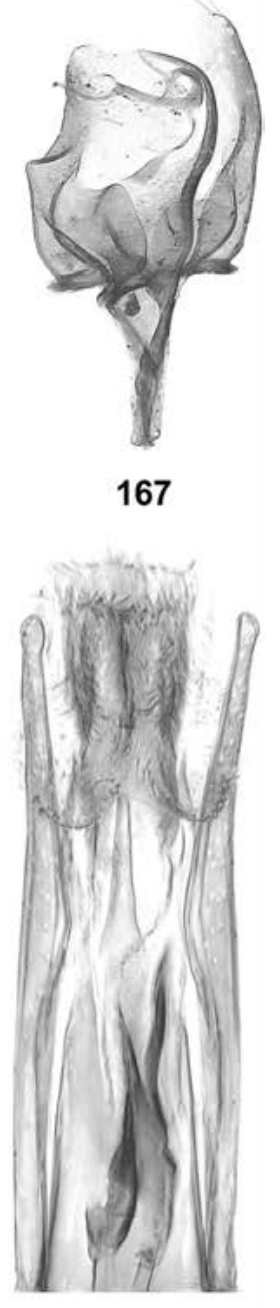

173

Figs 156-173: Amauronyx chanianus (156), A. occidens (157), A. askifouicus (158), Bryaxis meybohmianus (159-161), Bythinus creticus (162-163), Euplectus assingi (164), Faronus meybohmi (165), F. lefkamontium (166), F. albimontium (167), Tychus chanianus (168), and Sepedophilus creticus (169-173): aedeagus in dorsal and ventral view (156-158, 160, 163-168, 172); antennomeres I-II (159); internal structures of aedeagus (161); maxillary palpomere IV (162); habitus (169); male sternite VIII (170); male tergites IX-X (171); apical portion of aedeagus (173). Scale bars: 169: $1.0 \mathrm{~mm}$; 170-172: $0.2 \mathrm{~mm}$; 156-161, 163-168, 173: $0.1 \mathrm{~mm}$; 162 without scale. 

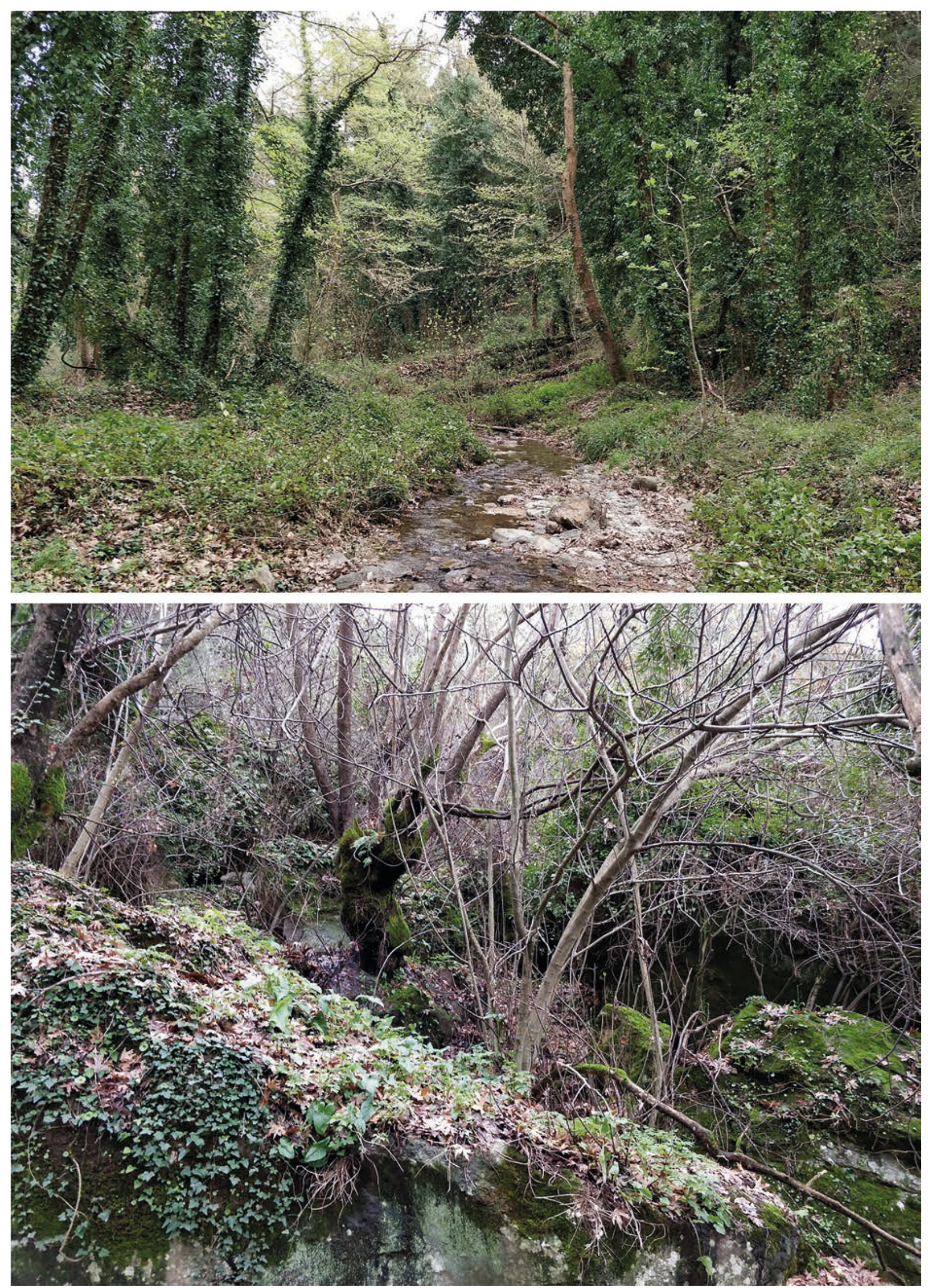

Figs 174-175: Type localities of Cretotyphlus chanianus and Allotyphlus foedatus in Mavros stream valley, West Crete (above), and of Cretotyphlus idanus, Cephennium idanum, and C. latius near Livadia, Psiloritis, Central Crete (below). 
Description: Body length 2.0-3.0 mm; length of forebody 1.0-1.2 mm. Coloration: head and pronotum yellowishbrown to dark-brown; elytra yellow to yellowish-brown; abdomen yellowish to pale-brown with segments IV-VI more or less extensively and more or less distinctly infuscate; legs yellow; antennae yellow to yellowish-brown, usually with the basal two antennomeres slightly paler.

External characters as in other Cretan representatives of Sipalotricha SCHEERPELTZ, 1931; distinguished only by the primary and secondary sexual characters:

$\sigma^{*}$ : posterior margin of tergite VIII (Fig. 32) smoothly convex or with very shallow median concavity; sternite VIII (Fig. 33) with convex posterior margin; median lobe of aedeagus (Figs 34-35) $0.3 \mathrm{~mm}$ long; internal sac with several moderately sclerotized spines of different lengths.

ㅇ: posterior margin of tergite VIII (Fig. 36) smoothly convex; sternite VIII (Fig. 37) posteriorly convex and with transverse row of rather long and stout marginal setae; spermatheca as in Fig. 38.

Comparative notes: Eight locally endemic species of Sipalotricha were previously known from Crete. The new species is distinguished from them by the (near) absence of a posterior excision of the male tergite VIII and additionally as follows:

from G. idaea (Psiloritis) by the shape of the crista apicalis and the ventral process of the aedeagus (G. idaea: ventral process curved in lateral view and apically abruptly narrowed in ventral view);

from G. exsecta (Psiloritis) by the absence of posterior concavities of the female tergite VIII and sternite VIII, by a much smaller crista apicalis, a differently shaped ventral process, the presence of spines in the internal sac of the aedeagus, and by the shape of the spermatheca;

from G. paulexsecta (Psiloritis) by the shape of the ventral process of the aedeagus both in lateral and in ventral view, and by the presence of distinct spines in the internal sac of the aedeagus;

from G. icaria (Lefka Ori) by a narrower (ventral view) and straight (lateral view) ventral process of the aedeagus, the presence of distinct spines in the internal sac, and by a much smaller distal portion of the spermatheca;

from G. albimontis (eastern Lefka Ori) by a straight (lateral view) and more slender (ventral view) ventral process of the aedeagus and by a spermatheca with a shorter and less slender proximal portion;

from G. meybohmi (Dikti) by the shape of the crista apicalis and a more slender ventral process of the aedeagus (ventral view), and by a shorter apical invagination of the spermatheca;

from G. diktiana (Dikti) by the shape of the ventral process of the aedeagus both in lateral and in ventral view, the presence of distinct spines in the internal sac, and by a much smaller distal portion of the spermatheca;

from G. thryptisensis (Orno Thripti) by the shapes of the crista apicalis and of the ventral process of the aedeagus (more slender and apically gradually narrowed), shorter spines in the internal sac, a smoothly convex posterior margin of the female tergite VIII (G. thryptisensis: posterior margin with median concavity), and by the shape of the spermatheca.

For illustrations of the Sipalotricha species previously known from Crete see Assing (1999, 2000, 2001, 2007, 2013, 2015).

Distribution and natural history: The currently known distribution is confined to two localities in the region to the east southeast of Rethimno, Central Crete. The specimens were washed from soil taken in a gallery forest with oak and alder and in a calcareous pasture with old oak trees at altitudes of 500 and $520 \mathrm{~m}$.

\section{Cousya candica Assing spec. nov.}

\section{urn:Isid:zoobank.org:act:44B00621-3DA4-462B-9491-AD4B45476F2E} (Figs 39-43)

Type material: Holotype $0^{\star}$ : "GR - Crete [18], S Kritsa, SW Kroustas, $35^{\circ} 07^{\prime} 03^{\prime \prime} \mathrm{N}, 25^{\circ} 38^{\prime} 10^{\prime \prime E}, 780 \mathrm{~m}$, litter sifted, 28.XII.2018, V. Assing / Holotypus o Cousya candica sp. n. det. V. Assing 2019” (cAss). Paratypes: $20^{\star} \sigma^{\star}, 2$ 우 우 [partly teneral]: same data as holotype (cAss); 1 : "GR - Kreta; Lassithi (6), N3507'03 E2538'10, Kroustas sw 770 m, 11.3.2018, leg. Meybohm \& Brachat” (cAss); 1 ㅇ: “GR - Kreta; Lassithi (8), N3507'02 E2537'55, Kroustas sw 800 m, 12.3.2018, leg. Meybohm \& Brachat” (cAss).

Etymology: The specific epithet is an adjective derived from Candia, the Latin and Venetian name for Crete.

Description: Body length $2.4-2.7 \mathrm{~mm}$; length of forebody $0.9-1.1 \mathrm{~mm}$. Habitus as in Fig. 39. Coloration: head blackish-brown to blackish; pronotum and elytra reddish-brown to dark-brown; abdomen blackish with the posterior portion of tergite VII and the anterior and posterior portions of tergite VIII pale-brown; legs yellow; antennae dark-brown to blackish with the basal two antennomeres yellowish.

Head approximately as broad as long; punctation fine and sparse; interstices with shallow microreticulation. Eyes shorter than postocular portion in dorsal view. Antenna short and incrassate, approximately $0.6 \mathrm{~mm}$ long; antennomeres III weakly oblong, IV-X distinctly transverse, approximately twice as broad as long, and gradually increasing in width, XI of ovoid shape, slightly shorter than the combined length of IX and X.

Pronotum moderately convex in cross-section, approximately 1.15 times as broad as long and 1.2 times as broad as head; posterior angles weakly marked; punctation very fine and moderately dense; interstices with shallow microreticulation.

Elytra $0.80-0.85$ times as long as pronotum; punctation fine, but more distinct than that of head and pronotum. Hind wings vestigial; wing rudiments slightly longer than elytra. Metatarsomere I approximately as long as the combined length of II and III. 
Abdomen narrower than elytra; anterior impressions of tergites III-V rather shallow; punctation fine and moderately dense; interstices with distinct microreticulation; posterior margin of tergite VII with narrow palisade fringe.

$\sigma^{*}$ : tergite VIII with strongly convex posterior margin; median lobe of aedeagus $0.3 \mathrm{~mm}$ long and shaped as in Figs 40-41; paramere (Fig. 42) nearly twice as long as median lobe and with rather short apical lobe.

o : sternite VIII with weakly convex posterior margin; spermatheca shaped as in Fig. 43.

Comparative notes: Based on external and sexual characters, C. candica belongs to the C. crocea group, whose representatives have very local distributions (exception: C. crocea Assing, 2004). Among the species of this group, it is characterized particularly by the morphology of the median lobe of the aedeagus. It is additionally distinguished from other Greek representatives of this group as follows:

from C. kelecsenyi (Bernhauer, 1914) (Paxos island; male unknown) by darker coloration and by the shape of the spermatheca (C. kelecsenyi: proximal portion shorter; apical invagination of different shape);

from C. sufflata Assing, 2018 (Pelopónnisos) by the shape of the spermatheca (C. sufflata: spermatheca proximally strongly dilated);

from C. dimorpha Assing, 2006 (North Greece) by paler coloration (C. dimorpha: body black; legs dark-brown) and the shape of the spermatheca (C. dimorpha: proximal shorter; apical invagination larger).

For illustrations of external and sexual characters of other Cousya species see Assing (2018a).

Distribution and natural history: The known distribution is confined to an old oak forest to the southwest of Kroustas in the eastern slopes of Dikti Oros, East Crete. The specimens were sifted from litter at altitudes of 770-780 m. Some of the type specimens collected in December are teneral.

\section{Oxypoda (Bessopora) bimontium Assing spec. nov. urn:Isid:zoobank.org:act:C38F6606-DE88-4E86-B1E8-AB0921804654 (Figs 44-46)}

Type material: Holotype + : “GR - Crete [11], NW Dikti Oros, Limnakaro, $35^{\circ} 08^{\prime} 08^{\prime \prime} \mathrm{N}, \quad 25^{\circ} 29^{\prime} 00^{\prime} \mathrm{E}, 1170 \mathrm{~m}$, under stones, 27.III.2012, V. Assing / Holotypus o Oxypoda bimontium sp. n. det. V. Assing 2019" (cAss). Paratypes: 1 ㅇ: same data as holotype (cAss); 1 : : same data, but 30.III.2012 (cAss); 1 우 "GR - Crete [28], S Anogia, Psiloritis, 35² $14^{\prime} 59^{\prime \prime} \mathrm{N}, 24^{\circ} 53^{\prime} 05^{\prime \prime} \mathrm{E}, 1180 \mathrm{~m}$, under stones, 3.IV.2012, V. Assing” (cAss); 1 \%: “GR - Crete [61], WSW Ag. Nikolaos, Katharo plateau, $1110 \mathrm{~m}$, stream, $35^{\circ} 08^{\prime} 14^{\prime \prime} \mathrm{N}, 25^{\circ} 34^{\prime} 15^{\prime \prime} \mathrm{E}, 28 . I I I .2018$, V. Assing" (cAss).
Etymology: The specific epithet is a noun in apposition composed of the Latin prefix bi- (two) and the genitive plural of the Latin noun mons (mountain). It alludes to the fact that this species was collected in two of the major mountain ranges of Crete.

Description: Body length 2.3-2.8 mm; length of forebody 1.1-1.2 mm. Habitus (Fig. 44) rather slender and with nearly parallel lateral margins in dorsal view. Coloration: head black; pronotum and elytra brown to blackish; abdomen blackish; legs dark-yellow; antennae brown to blackish-brown with the basal three antennomeres reddish; maxillary palpi brown to blackish-brown with the apical palpomere paler.

Head (Fig. 45) approximately as broad as long, rather large in relation to pronotum; punctation conspicuously coarse and dense; interstices with shallow microreticulation. Eyes flat, shorter than postocular portion in dorsal view. Antenna short and incrassate apically, approximately $0.6 \mathrm{~mm}$ long; antennomeres III weakly oblong, IV moderately transverse, $\mathrm{V}-\mathrm{X}$ distinctly transverse, of gradually increasing width and increasingly transverse, $\mathrm{X}$ nearly twice as broad as long, and XI of conical shape, slightly longer than the combined length of IX and X.

Pronotum (Fig. 45) moderately convex in cross-section, approximately 1.2 times as broad as long and 1.25 times as broad as head; posterior angles marked; punctation very dense and coarse; interstices with shallow microreticulation.

Elytra (Fig. 45) short, approximately 0.65 times as long as pronotum; punctation very dense, coarse, and somewhat confluent. Hind wings vestigial, reduced to short stubs. Metatarsomere I nearly as long as the combined length of II-IV.

Abdomen approximately as broad as elytra; segments III-VI of subequal width; anterior impressions of tergites III-V rather shallow; punctation fine and dense; interstices without microreticulation; posterior margin of tergite VII with narrow rudiment of a palisade fringe.

$\sigma^{*}$ : unknown.

o: sternite VIII with weakly convex posterior margin, with weakly modified and rather long marginal setae; spermatheca shaped as in Fig. 46.

Comparative notes: Based on external characters, this species is closely allied to Oxypoda brachyptera (STEPHENS, 1832) and related species. It differs from other micropterous species known from Crete (O. cretica Assing, 2006, O. idana Assing, 2013) by numerous characters (each of them sufficient for a reliable identification), particularly much darker coloration, a smaller and a much more slender body, significantly shorter antennae, a much narrower pronotum, significantly coarser punctation of the forebody, the presence of a narrow rudiment of a palisade fringe, and by the shape of the spermatheca. It is distinguished from the brachypterous morph of the widespread wing-dimorphic O. lesbia Assing, 2005 by a larger and broader body, significantly 
shorter elytra, even coarser punctation of the forebody, darker coloration, less transverse antennomeres $\mathrm{V}-\mathrm{X}$ (in O. lesbia more than twice as broad as long), longer tarsi and a longer metatarsomere I, and by the shape of the spermatheca. In body shape, body size, and antennal morphology, O. bimontium is somewhat similar to O. afimbriata Assing, 2006 (Pelopónnisos). It differs from this species by coarser punctation of the forebody, darker coloration of the head, the presence of a narrow palisade fringe at the posterior margin of tergite VII, and by the shape of the spermatheca. For illustrations of O. cretica, O. idana, O. lesbia, and O. afimbriata see Assing (2005, 2006a, 2013).

Distribution and natural history: The specimens were collected in three localities in the Dikti and Psiloritis ranges at altitudes of 1110-1180 m. Most of them were found under stones near snow; one was floated from gravel on the bank of a stream (most likely an accidental find). The three specimens collected in 2012 were reported as Oxypoda (brachyptera group) sp. by Assing (2013).

\section{Oxypoda (Mycetodrepa) retunsa Assing spec. nov. urn:Isid:zoobank.org:act:D801AADC-CC6A-4E15-8988-BE8CCEA48013 (Figs 47-56)}

Type material: Holotype $0^{*}$ : "GR - Crete [11a], NW Dikti Oros, Limnakaro, 350' $08^{\prime \prime N}, 25^{\circ} 29^{\prime} 00^{\prime E}$, 1170 m, sifted, 27.III.2012, V. Assing / Holotypus ơ Oxypoda retunsa sp. n. det. V. Assing 2019" (cAss). Paratypes: $3 \sigma^{\top} o^{\star}$ : same data as holotype (cAss); 1 ㅇ: same data, but "[10a] ... 26.III.2012" (cAss); 1 o : same data, but "[17a] ...

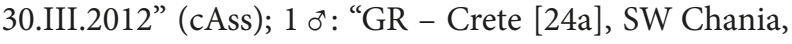
SW Prases, $35^{\circ} 21^{\prime} 32^{\prime \prime} \mathrm{N}, 23^{\circ} 49^{\prime} 28^{\prime \prime E}, 740 \mathrm{~m}$, litter sifted, 20.III.2018, V. Assing” (cAss); 1 ㅇ: "GR - Crete [33],

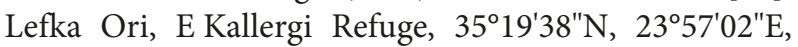
$1460 \mathrm{~m}$, litter \& grass, 22.III.2018, V. Assing” (cAss); 1 ơ: "GR - Crete [36], SW Chania, SW Prases, 3521'30"N, $23^{\circ} 49^{\prime} 40^{\prime E}$, $820 \mathrm{~m}$, sifted, 22.III.2018, V. Assing” (cAss); $3 o^{\top} o^{\star}, 1$ \% : "GR - Crete, Hiraklion, Abelakia Oros, $35^{\circ} 09^{\prime} 52^{\prime \prime} \mathrm{N}, \quad 24^{\circ} 55^{\prime} 36^{\prime \prime E}, 1030 \mathrm{~m}$, VI.2016-VI.2018, Giachino \& Vailati” (cAss); 1 ㅇ: “3505'17 E2551'54, GR Ostkreta (2), Thripti $880 \mathrm{~m} \mathrm{10.3.2018,} \mathrm{1.} \mathrm{Brachat}$ \& Meybohm” (cAss); 1 ㅇ: “N350'45 E253' 30, GR Lassithi (5), Kritsa s 390 m, 11.3.2018, 1. Brachat \&

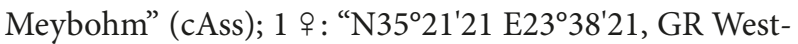
kreta (28), Elos 610 m, 21.3.2018, 1. Brachat \& Meybohm"

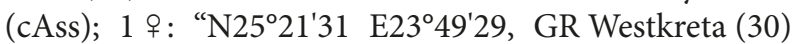
Prases, $10 \mathrm{~km} \mathrm{w}$ Omalos $760 \mathrm{~m}$, Brachat \& Meybohm 22.3.2018” (cAss); 1 ㅇ: "N35²19'07 E2354'46, GR Kreta 1080 m, Omalos E 23.3.2019, Brachat \& Meybohm 2019” (cAss).

Etymology: The specific epithet (Latin, adjective: blunt) alludes to the shape of the apex of the ventral process of the aedeagus (lateral view).
Description: Body length $2.7-3.5 \mathrm{~mm}$; length of forebody $1.2-1.6 \mathrm{~mm}$. Habitus as in Fig. 47. Coloration: head blackish; pronotum bright reddish; elytra yellowish with the scutellar and the postero-lateral portions more or less distinctly and more or less extensively infuscate; abdomen pale-reddish with segments VI, the posterior portion of segment $\mathrm{V}$, and the anterior portion of segment VII blackish; legs yellowish; antennae dark-brown to blackish-brown with the basal two antennomeres paler; maxillary palpi dark-yellowish with palpomere III often somewhat infuscate.

Head (Fig. 48) approximately as broad as long, with distinct microsculpture and moderately dense and rather fine punctation. Eyes weakly convex, approximately as long as postocular portion in dorsal view. Antenna (Fig. 49) 0.8-0.9 mm long; antennomeres III-X distinctly transverse. Maxillary palpi with palpomere III moderately slender, approximately three times as long as broad.

Pronotum (Fig. 48) relatively small, 1.15 times as broad as long and 1.25-1.30 times as broad as head; punctation denser and more distinct than that of head; interstices with pronounced microsculpture.

Elytra (Fig. 48) 1.00-1.15 times as long as pronotum; punctation dense and fine. Hind wings fully developed. Metatarsomere I longer than the combined length of metatarsomeres I and II, but shorter than the combined length of metatarsomeres I-III.

Abdomen with punctation dense and fine, finer on posterior than on anterior tergites; posterior margin of tergite VII with palisade fringe.

$\sigma^{*}$ : sternite VIII (Fig. 50) posteriorly distinctly produced in the middle; aedeagus (Figs 51-53) $0.28-0.32 \mathrm{~mm}$ long; ventral process apically short, stout, and rounded in ventral view, apico-laterally with pronounced lateral folds; paramere $0.47-0.50 \mathrm{~mm}$ long and shaped as in Fig. 54.

오 sternite VIII (Fig. 55) with weakly convex, nearly truncate posterior margin and with weakly modified and rather short marginal setae; spermatheca shaped as in Fig. 56.

Comparative notes: Based on external (habitus, coloration, punctation) and the primary sexual characters, $O$. retunsa is most similar and most closely related to the widespread O. formosa KRAATZ, 1856. It is distinguished from this species by smaller average body size, a more slender habitus, and particularly by a smaller aedeagus with an apically stouter, shorter and more rounded ventral process (lateral view) and with more pronounced apico-lateral folds (O. formosa: median lobe of the aedeagus $0.35-0.36 \mathrm{~mm}$ long). Oxypoda retunsa differs from the similarly small, mostly parthenogenetic O. turcica ZERCHE, 1999 by a more distinctly bicoloured body with a bright reddish pronotum (O. turcica: pronotum usually yellowish to yellowish-brown), longer elytra, and the shape of the spermatheca. For illustrations of the genitalia of O. formosa and O. turcica see ZERCHE (1999). 
Distribution and natural history: The type material was collected in several localities distributed across most of Crete mostly by sifting litter, grass roots, and moss both in forested and unforested habitats; four specimens were collected with subterranean pitfall traps. The altitudes range from 390 to $1460 \mathrm{~m}$. Some specimens collected in March are somewhat teneral.

\section{Genus Typhlocyptus SAULCY, 1878}

Typhlocyptus previously included two valid species, the type species T. pandellei SaUlCy, 1878 (South Europe) and T. loebli PaCe, 1985 (North India) (Schülke \& SMetana 2015). Typhlocyptus pandellei has two junior synonyms T. atomus ReY, 1882 (described from Southeast France) and T.halleri Matcha, 1916 (described from Montenegro). According to Schülke \& SMetana (2015), the species is widespread from France, Switzerland, and Italy across the Balkans (Croatia, Greece) eastwards to Azerbaijan. It was recently reported from Montenegro and tentatively from Crete (Assing 2018b).

Typhlocyptus pandellei is a minute beetle (length of forebody $0.4-0.5 \mathrm{~mm}$; body length $0.6-0.9 \mathrm{~mm}$, depending on how much the abdomen is extended). It is anophthalmous, apterous, and weakly pigmented and, based on personal observations, lives in a subterranean habitat. A winged morph is unknown. Against this background, both a wide distribution and its presence in Crete would appear most remarkable and implausible.

A major problem for a taxonomic approach to this problem based on morphological characters is the uniformity not only of external, but also of the male sexual characters. The aedeagus of Typhlocyptus is of a unique and highly derived morphology: the minute, depigmented, and structurally simple ventral process and parameres are conspicuously separated from the basal capsule; both are connected only by a long transparent tube (Figs 57-58). In consequence, a dissection of a complete aedeagus is possible only in fresh and soft specimens. The basal portion of the aedeagus is of uniform shape in all the examined material. Slight differences, however, were found in the shape of the ventral process between populations from Crete and from the mainland. Whether or not the mainland populations all belong to the same species can be assessed only using a DNA-based approach.

\section{Typhlocyptus pandellei SAULCY, 1878} (Figs 61-62)

Material examined: Italy: 5 exs., Genova, leg. Dodero (MNB, NHMW); 3 exs., Genova env., Dinegro, 20.VI.1903, leg. Dodero (NHMW); 1 ex., Elba, leg. Moczarski (NHMW). Croatia: 1 ex., Mljet (island), 1907, leg. Moczarski (NHMW). Montenegro: 1 ex., HerzegNovi env., Savina, leg. Kaiser (NHMW); 1 ex., Radoštak (mountain), leg. Kaiser (NHMW). Greece: Corfu: 7 exs.,
Val de Ropa, 1926, leg. Beier \& Moczarski (NHMW). Kefalonia: 7 exs., Krane, 1926, leg. Moczarski \& Beier (NHMW).

Comment: The specimens from Elba, Corfu, and Kefalonia are labelled as types of Typhlocyptus elbanus Scheerpeltz, T. corcyricus Scheerpeltz, and T. cephallenicus SCHEERPELTZ, respectively, all of them manuscript names. Most of the specimens from Kefalonia lack an abdomen, suggesting that someone previously attempted to dissect them.

A study of the aedeagus (Figs 61-62) of males from Genova, Corfu, and Kefalonia revealed only indistinct differences in the shape of the ventral process of the aedeagus (apex slightly sharper in the specimens from the Ionian islands than in those from Italy), so that all of them are attributed to T. pandellei for the time being.

\section{Typhlocyptus creticus Assing spec. nov. urn:Isid:zoobank.org:act:2F3A6D48-5EA3-417D-9DB3-F8E0139432F6 (Figs 57-60)}

Type material: Holotype ơ: "GR - Crete [38], SW Chania, S Nteres, 3524'15"N, 2350'58"E, $330 \mathrm{~m}$, soil washing, 22.III.2018, V. Assing / Holotypus o Typhlocyptus creticus sp. n. det. V. Assing 2018" (cAss). Paratypes: $26 o^{\top} o^{\top}, 26$ 우 옹 same data as holotype (cAss, cFel); $1 o^{\star}$ : "GR - Crete [37], SW Chania, S Nteres, 35²4'00"N, 2351'00"E, $360 \mathrm{~m}$, soil washing, 22.III.2018, V. Assing” (cAss, cFel); 1 : "GR - Crete [13], S Kritsa, 350' 47 "N, 253'ㄴㄹ" $400 \mathrm{~m}$, soil washing, 27.XII.2017, V. Assing” (cAss); 1 ㅇ: "GR - Crete [18], SW Sitia, NW Makrigialos, $35^{\circ} 03^{\prime} 31^{\prime \prime N}, 25^{\circ} 56^{\prime} 49^{\prime \prime E}, 70 \mathrm{~m}$, soil washing, 30.XII.2017, V. Assing" (cAss).

Etymology: The specific epithet is an adjective derived from Creta.

Description: Length of forebody $0.4-0.5 \mathrm{~mm}$. Colour of body yellow.

External characters as in Typhlocyptus pandellei.

$0^{*}$ : median lobe of aedeagus (Figs 57-60) distinctly curved in lateral view and somewhat abruptly narrowed apically in ventral view.

Comparative notes: Typhlocyptus creticus is distinguished from $T$. pandellei only by the shape of the ventral process of the aedeagus, which is straight in lateral view and gradually tapering apically in ventral view in T. pandellei. For comparison, the apical portion of the aedeagus of T. pandellei is illustrated in Figs 61-62.

Distribution and natural history: The distribution of T. creticus is most likely confined to Crete, where it is currently known from four localities in the west and in the east. The two female paratypes from East Crete were recorded as T.pandellei in Assing (2018b). All type 
specimens were collected by washing soil, three of them as singletons in a dry stream valley with Quercus ilex, in a valley with a temporary small stream with Platanus orientalis, bushes, undergrowth, and reed, and in a stream valley with old chestnut and with fern and herb undergrowth. As many as 53 specimens were found in the type locality, a slope with very old chestnut, fern, and herbs. The altitudes range from 70 to $400 \mathrm{~m}$.

\section{Osoriinae}

\section{Geomitopsis cretica Assing spec. nov. urn:Isid:zoobank.org:act:1D3E575E-A726-422D-BA91-AF9B98BCA2BD (Figs 63-64)}

Type material: Holotype $\sigma^{\star}:$ "GR - Crete [16], Zakros, $35^{\circ} 06^{\prime} 57^{\prime \prime} \mathrm{N}, 26^{\circ} 13^{\prime} 10^{\prime E} \mathrm{E}, 190 \mathrm{~m}$, dry stream valley, soil washing, 27.XII.2018, V. Assing / Holotypus ơ Geomitopsis cretica sp. n. det. V. Assing 2019” (cAss). Paratypes: 2 우 우: same data as holotype (cAss); $10^{*}:$ "GR - Crete [19], S Kritsa, SW Kroustas, 3507'01"N, 2537'55"E, 810 m, soil washing, 28.XII.2018, V. Assing” (cAss).

Etymology: The specific epithet is an adjective derived from Creta, where this species is most likely endemic.

Description: 1.9-2.1 mm (abdomen extended), length of forebody $0.65-0.75 \mathrm{~mm}$. Colour of body pale reddishbrown; legs yellow; antennae reddish-yellow.

Head distinctly dilated posteriad, distinctly separated from neck in dorsal view; punctation indistinct in the pronounced microreticulation. Eyes completely reduced. Antenna $0.35-0.39 \mathrm{~mm}$ long, with three-jointed club; antennomeres III-X strongly transverse, V and VII distinctly broader than neighbouring antennomeres.

Pronotum approximately as broad as long and slightly narrower than head; disc with few coarser punctures; micropunctation indistinct; microreticulation similar to that of head.

Elytra approximately 0.8 times as long as pronotum; punctation indistinct; microreticulation composed of larger meshes than that of head and pronotum. Hind wings completely reduced.

Abdomen with microsculpture composed of large isodiametric meshes; punctation indistinct.

$\mathrm{o}^{*}$ : aedeagus $0.2 \mathrm{~mm}$ long and shaped as in Figs 63-64.

Comparative notes: The aedeagus of G. cretica is similar to that of G. anatolica CoIfFAIt, 1979 (Turkey: Mersin), but distinguished by a more strongly excavate and apically longer ventral process (lateral view) and differently shaped parameres. For illustrations of G. anatolica see Coiffait (1979).

Distribution and natural history: The specimens were collected by soil washing in two localities in East Crete. The type locality is a dry temporary stream valley with
Platanus orientalis at an altitude of $190 \mathrm{~m}$, the second locality a rocky forest with old Quercus ilex and old pine trees at an altitude of $810 \mathrm{~m}$.

\section{Leptotyphlinae}

\section{Allotyphlus (Moreotyphlus) foedatus Assing spec. nov. urn:Isid:zoobank.org:act:42A89E7C-F33A-43C8-A301-296D27AD2BBF (Figs 65-70, 174)}

Type material: Holotype $0^{*}$ : "GR - Crete [7], SW Chania,

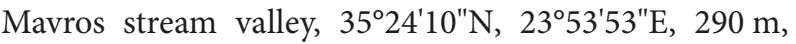
18.III.2018, V. Assing / Holotypus o Allotyphlus foedatus sp. n. det. V. Assing 2018” (cAss). Paratypes: $13 \sigma^{\top \top} \sigma^{\top}$, 8 ㅇ 오: same data as holotype (cAss, MNB); $150^{*} o^{*}, 11$ 우 우: "GR - Crete [5], SW Chania, W Lakki, 35²3'37"N, $23^{\circ} 55^{\prime} 08^{\prime \prime E}, 600 \mathrm{~m}$, soil washing, 17.III.2018, V. Assing” (cAss, MNB); 1 o , 1 우: “GR - Crete [6], S Chania N Theriso, $35^{\circ} 24^{\prime} 52^{\prime \prime} \mathrm{N}, 23^{\circ} 59^{\prime} 14^{\prime \prime E}, 610 \mathrm{~m}$, soil washing under Platanus, 17.III.2018, V. Assing" (cAss); $120^{\top} \sigma^{*}, 12$ 우 : "GR - Crete [8], SW Chania, Mavros stream valley, $35^{\circ} 23^{\prime} 42^{\prime \prime N}, 23^{\circ} 54^{\prime} 04^{\prime} \mathrm{E}, 400 \mathrm{~m}$, 18.III.2018, V. Assing” (cAss); 2 o $^{\star}$, 4 우 우: “GR - Crete [9], SW Chania, Mavros

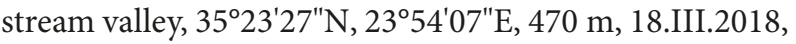
V. Assing” (cAss); $7 \circ^{\star} o^{\star}, 7$ \% $\%$ : “GR - Crete [11], SW Chania, Mavros stream valley, 352 $23^{\prime} 56^{\prime \prime} \mathrm{N}, 23^{\circ} 53^{\prime} 46^{\prime \prime} \mathrm{E}$, $380 \mathrm{~m}$, 18.III.2018, V. Assing" (cAss, MNB); $10^{\star}$ : "GR - Crete [17], S Kissamos, NE Sirikari, 35²4'44"N, 2338'36"E, $500 \mathrm{~m}$, soil washing, 19.III.2018, V. Assing” (cAss); $1 \sigma^{*}$ : "GR - Crete [21], SW Chania, WSW Chliaro, $35^{\circ} 24^{\prime} 26^{\prime \prime} \mathrm{N}, 23^{\circ} 53^{\prime} 15^{\prime \prime} \mathrm{E}, 210 \mathrm{~m}$, soil washing, 20.III.2018, V. Assing” (cAss); 1 우 :GR - Crete [22], SW Chania,

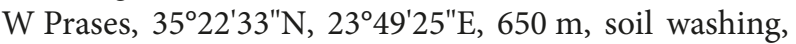
20.III.2018, V. Assing” (cAss); 3 ㅇ ㅇ: "GR - Crete [24], SW Chania, SW Prases, 35⒉ $32^{\prime} \mathrm{N}, 23^{\circ} 49^{\prime} 28^{\prime \prime} \mathrm{E}, 740 \mathrm{~m}$, soil washing, 20.III.2018, V. Assing" (cAss); $6 o^{\star} o^{*}, 2$ 우 우: "GR - Crete [25], SW Chania, SW Prases, 3521'43"N, $23^{\circ} 49^{\prime} 24^{\prime E} \mathrm{E}, 640 \mathrm{~m}$, soil washing, 20.III.2018, V. Assing” (cAss); $10^{\star}, 1$ : : "GR - Crete [26], SW Chania, SW Prases, $35^{\circ} 21^{\prime} 43^{\prime \prime} \mathrm{N}, 23^{\circ} 49^{\prime} 28^{\prime \prime} \mathrm{E}, 650 \mathrm{~m}$, soil washing, 20.III.2018, V. Assing" (cAss); $2 o^{*} o^{*}$ : "GR - Crete [28], S Kissamos,

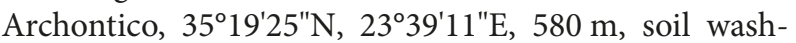
ing, 21.III.2018, V. Assing" (cAss); 1 ơ: "GR - Crete [30], S Kissamos, Strovles, 3521'47"N, 2340'24"E, 470 m, soil washing, 21.III.2018, V. Assing" (cAss); $10^{\star}, 1$ 우 “GR -

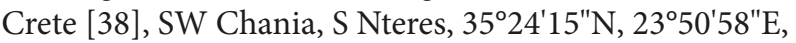
$330 \mathrm{~m}$, soil washing, 22.III.2018, V. Assing" (cAss); 1 \% : "GR - Crete [45], SW Chania, S Nteres, 35²4'48"N, $23^{\circ} 50^{\prime} 46^{\prime E} \mathrm{E}, 280 \mathrm{~m}$, soil washing, 24.III.2018, V. Assing” (cAss); $30^{\star} o^{*}, 3$ 우: "GR - Crete [46], SW Chania, N Nteres, $35^{\circ} 27^{\prime} 40^{\prime \prime} \mathrm{N}, 23^{\circ} 50^{\prime} 19^{\prime \prime} \mathrm{E}, 170 \mathrm{~m}$, soil washing,

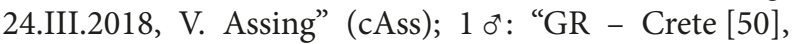
E Kandanos, Anisaraki, 35¹9'53"N, 2345'34"E, 560 m, soil washing, 25.III.2018, V. Assing” (cAss); 1 ㅇ: "GR Crete [52], SE Kandanos, $35^{\circ} 19^{\prime} 17^{\prime \prime} \mathrm{N}, \quad 23^{\circ} 45^{\prime} 33^{\prime \prime} \mathrm{E}$, $670 \mathrm{~m}$, old oak tree, soil washing, 25.III.2018, V. Assing” (cAss); 1 : "GR - Crete [43], S Asigonia, E Kallikratis, 
$35^{\circ} 14^{\prime} 58^{\prime \prime} \mathrm{N}, 24^{\circ} 16^{\prime} 38^{\prime \prime} \mathrm{E} 770 \mathrm{~m}$, soil washing, 23.III.2018, V. Assing” (cAss); $10^{*}, 1$ \% : "GR - Crete [1], SW Chania, WSW Lakki, $35^{\circ} 23^{\prime} 54^{\prime \prime} \mathrm{N}, 23^{\circ} 54^{\prime} 47^{\prime \prime} \mathrm{E}, 430 \mathrm{~m}$, stream valley, 22.XII.2018, V. Assing” (cAss, MNB); 1 \%: “GR - Crete [2], SW Chania, WSW Lakki, 35²3'53"N, $23^{\circ} 54^{\prime} 38^{\prime \prime E}, 390 \mathrm{~m}$, stream valley, 22.XII.2018, V. Assing" (MNB); $7 o^{\star} o^{\star}, 5$ 우 + : same data, but "[2a]" (cAss, MNB); $10^{\star}$ : same data, but "[2b]" (cAss); $10^{*}$ : “GR - Crete [5], S Kissamos, Elos, $35^{\circ} 21^{\prime} 33^{\prime \prime N}, 23^{\circ} 38^{\prime} 21^{\prime \prime E}, 580 \mathrm{~m}$, old chestnut, soil washing, 23.XII.2018, V. Assing" (cAss); 10 , 3 우 우: “GR - Crete [10], SW Chania, Mavros stream valley, 3524'10"N, 2353'53"E, 290 m, 24.XII.2018, V. Assing" (cAss, MNB).

Etymology: The specific epithet is the past participle of the Latin verb foedare (to deform) and alludes to the strongly asymmetric male sternite VIII and aedeagus.

Description: 1.2-1.6 mm (abdomen extended), length of forebody $0.44-0.60 \mathrm{~mm}$; males on average slightly larger than females. Colour of body dark-yellowish.

External characters as in Allotyphlus candicus Assing, 2018, except for the slightly less pronounced microsculpture of the head.

$\sigma^{*}$ : posterior margin of tergite VIII strongly convex; sternite VIII strongly asymmetric, with a pronounced postero-median impression and a posterior excision of distinctive shape (Figs 65-66); median lobe of aedeagus (Figs 67-70) approximately $0.25 \mathrm{~mm}$ long; ventral process strongly asymmetric.

온 tergite VIII with weakly convex posterior margin; sternite VIII strongly convex posteriorly.

Comparative notes: Allotyphlus foedatus is reliably distinguished from the externally nearly identical $A$. candicus from East Crete by the completely different shape of the male sternite VIII, by the shape of the ventral process of the aedeagus, as well as by the shapes of the female tergite and sternite VIII. For illustrations of $A$. candicus see Assing (2018b).

Distribution and natural history: This species is evidently quite common and widespread in West Crete eastwards to the Askifou plateau (to the west of Lefka Ori). The specimens were collected from soil in a variety of habitats, mostly in permanent and temporary stream valleys and on moist slopes with Platanus orientalis, chestnut, and oak trees, often with Rubus and/or fern undergrowth; the type locality is illustrated in Fig. 174. The altitudes range from 140 to $770 \mathrm{~m}$. In two localities, they were found together with Kenotyphlus virgatus, in one with Cretotyphlus chanianus. The sex ratio is balanced.
Kenotyphlus virgatus Assing spec. nov. urn:Isid:zoobank.org:act:1967E04F-CD26-4976-928F-B9A195790332 (Figs 71-73)

Type material: Holotype $0^{\star}:$ "GR - Crete [17], S Kissamos,

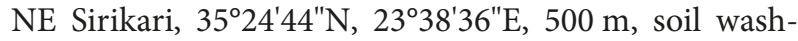
ing, 19.III.2018, V. Assing / Holotypus o Kenotyphlus virgatus sp. n. det. V. Assing 2018" (cAss). Paratypes: $4 o^{\pi} \# o^{\star}, 13$ 우 9 : same data as holotype (cAss, MNB); $1 o^{\star}$, 4 우 우: “GR - Crete [32], S Kissamos, Elos, 3521'49"N, 2338'18"E, $500 \mathrm{~m}$, soil washing, 21.III.2018, V. Assing” (cAss, MNB); 5 ㅇ 우 : "GR - Crete [14], S Kissamos, Aikirgianis, $35^{\circ} 25^{\prime} 45^{\prime \prime} \mathrm{N}, 23^{\circ} 40^{\prime} 36^{\prime \prime} \mathrm{E}, 290 \mathrm{~m}$, soil washing, 19.III.2018, V. Assing” (cAss, MNB); 1 \%: “GR - Crete

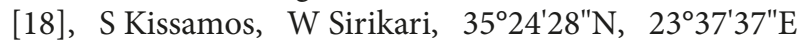
$470 \mathrm{~m}$, soil washing, 19.III.2018, V. Assing” (cAss); 2 우 우: "GR - Crete [31], S Kissamos, NE Elos, 35²2'04"N, $23^{\circ} 38^{\prime} 19^{\prime E}$, $460 \mathrm{~m}$, soil washing, 21.III.2018, V. Assing” (cAss, MNB); 2 우 ㅇ: “GR - Crete [11], SW Chania, Mavros stream valley, $35^{\circ} 23^{\prime} 56^{\prime \prime} \mathrm{N}, 23^{\circ} 53^{\prime} 46^{\prime \prime} \mathrm{E}, 380 \mathrm{~m}$, 18.III.2018, V. Assing" (cAss, MNB); 1 \%: "GR - Crete [44], Asigonia, $35^{\circ} 16^{\prime} 08^{\prime \prime} \mathrm{N}, 24^{\circ} 16^{\prime} 55^{\prime \prime} \mathrm{E}, 380 \mathrm{~m}$, soil washing, 23.III.2018, V. Assing" (cAss).

Etymology: The specific epithet is an adjective derived from the Latin noun virga (rod) and alludes to the long and slender sclcrotized internal structure of the aedeagus.

Description: 1.1-1.4 mm (abdomen extended), length of forebody $0.4-0.5 \mathrm{~mm}$. Colour of body dark-yellowish to yellowish-red.

External characters as in Kenotyphlus creticus Assing, 2018, distinguished only by the male sexual characters.

$\mathrm{o}^{\star}$ : posterior margin of tergite VIII weakly convex; sternite VIII distinctly oblong and with rather large and deep posterior excision of trapezoid shape (Fig. 71); median lobe of aedeagus (Figs 72-73) approximately $0.25 \mathrm{~mm}$ long and strongly asymmetric; ventral process of distinctive shape; parameres strongly asymmetric, right paramere (ventral view) with four long apical setae; internal sac with a long sclerotized rod-shaped structure.

: tergite VIII similar to that of male; sternite VIII longer than the corresponding sternite and with strongly convex posterior margin.

Comparative notes: Kenotyphlus virgatus is distinguished from the externally practically identical $K$. creticus from East Crete only by the slightly different shape of the posterior excision of the male sternite VIII and especially by the completely different shapes of the ventral process, the parameres, and the internal structures of the distinctly longer aedeagus. For illustrations of K. creticus see Assing (2018b).

Distribution and natural history: The vast majority of specimens was collected in five localities to the south of 
Kissamos in the extreme west of Crete. The female-based records from one locality in the Mavros stream valley and another locality in the immediate vicinity of Asigonia require confirmation. The specimens from the type locality, where as many as 18 individual were found, were collected from soil in a stream valley with old Platanus orientalis, those from Elos (five specimens) in a ruderal habitat with old oak trees, those from Aikirgianis (five specimens) in a steep stream valley with Platanus orientalis. The remaining two localities in the region to the south of Kissamos include a slope with old Platanus orientalis with rich undergrowth and the vicinity of a stream with Platanus orientalis and Quercus sp. The altitudes range from 290 to $500 \mathrm{~m}$. In two localities, the species was collected together with Allotyphlus foedatus. The sex ratio is biased: only six in a total of 34 specimens are males.

\section{Cretotyphlus Assing gen. nov.}

Type species: Cretotyphlus hamatus Assing spec. nov.; present designation.

Etymology: The name (gender: masculine) is composed of Creta and typhlus (from Greek typhlos: the blind).

Description: Species of intermediate to relatively "large" size. Antenna 11-jointed and moderately incrassate, apical antennomeres without sensorial appendages, the apical three antennomeres larger, longer, forming a club, these antennomeres with dense long pubescence. Mandibles apically bifid. Gular sutures close, but not contiguous anteriorly (Figs 76, 87). Labrum tridentate, i.e., with a pronounced median tooth and a smaller tooth on either side. Maxillary palpi with palpomeres II and III enlarged and somewhat flattened, III larger than II. Abdominal sternites without transverse sulcus at base (Fig. 82). Procoxal cavities without suture anteriorly. Tarsi three-jointed.

$\sigma^{*}$ : posterior sternites (V-VIII or VI-VIII) each with extensive median impression, these impressions gradually becoming more pronounced towards sternite VIII (Fig. 82); sternite VIII (Figs 77, 85, 88) symmetric (or nearly so) and with modified pubescence; aedeagus with long, slender, and apically acute ventral process, with slender dorsal portion, and without parameres.

o : sternite VIII angularly produced posteriorly; genital segment with more or less distinct pair of sclerotized internal structures (Figs 80, 91).

Comparative notes: Based on the morphogical characters indicated above, Cretotyphlus is assigned to the Metrotyphlini. Using the key to West Palaearctic Leptotyphlinae in Coiffait (1972), Cretotyphlus would key out together with Gynotyphlus CoIfFAIT, 1955, a genus currently including two species of doubtful status from Corfu and the north of mainland Greece, as well as a common and widespread polymorphic and parthenogenetic species,
G. perpusillus (Dodero, 1900). The new genus is distinguished from Gynotyphlus by larger body size, longer, less compact, and less incrassate antennae with less transverse antennomeres, longer mandibles, the ventral aspect of the head (Gynotyphlus: gular sutures distinctly contiguous anteriorly), and the absence of sulci on the pronotum.

Distribution: The genus currently includes three endemic species in Crete, all of them apparently very local and rare.

\section{Cretotyphlus hamatus Assing spec. nov. urn:Isid:zoobank.org:act:EBE1B406-3145-411C-883D-A9499AEF52BA (Figs 74-79)}

Type material: Holotype o $0^{\text {: }}$ "GR - Crete [56], NE Lassithi Plateau, $35^{\circ} 12^{\prime} 45^{\prime \prime} \mathrm{N}, 25^{\circ} 31^{\prime} 53^{\prime \prime} \mathrm{E}, 850 \mathrm{~m}$, soil washing, 27.III.2018, V. Assing / Holotypus $\sigma^{*}$ Cretotyphlus hamatus sp. n. det. V. Assing 2019” (cAss). Paratypes: 2 우 우: “GR - Crete [9], NE Lassithi Plateau, 3512'45"N, $25^{\circ} 31^{\prime} 53^{\prime \prime E}, 850 \mathrm{~m}$, soil washing, 26.XII.2017, V. Assing" (cAss); 1 우: "GR - Crete [25], NE Lassithi Plateau, $35^{\circ} 12^{\prime} 45^{\prime \prime} \mathrm{N}, 25^{\circ} 31^{\prime} 53 " \mathrm{E}, 850 \mathrm{~m}$, soil washing, 30.XII.2018, V. Assing" (cAss).

Etymology: The specific epithet (Latin, adjective: hooked) alludes to the pronounced spine on the ventral process of the aedeagus.

Description: 1.3-1.5 mm (abdomen extended), length of forebody approximately $0.6 \mathrm{~mm}$. Habitus as in Fig. 74 . Colour of body dark-yellowish.

Head (Fig. 75) with sparse, barely visible punctation and with very shallow microsculpture; ventral aspect as in Fig. 76. Pronotum (Fig. 75) approximately as long as broad and slightly narrower than head, with moderately fine and rather sparse punctation. Elytra (Fig. 75) without microsculpture and with very sparse, extremely fine punctation barely visible even at a magnification of $150 \mathrm{x}$.

Abdomen with microsculpture composed of large meshes only in anterior third to anterior half of tergites; punctation extremely fine and moderately dense; pubescence long, pale, sub-erect to erect, and moderately dense; posterior margin of tergite VIII truncate in both sexes.

$\sigma^{*}$ : sternite VIII (Fig. 77) symmetric and approximately as long as broad, with a cluster of moderately modified setae in the middle and with broadly concave posterior excision; aedeagus (Figs 78-79) $0.28 \mathrm{~mm}$ long, weakly asymmetric; ventral process long, slender, and somewhat sinuate, with a pronounced ventral tooth approximately in the middle.

o : sternite VIII longer than male sternite VIII, posteriorly angularly produced; segments IX-X with a pair of distinctly sclerotized structures of characteristic shapes (Fig. 80). 
Distribution and natural history: Despite extensive soil sampling, C. hamatus was found only in one locality to the northeast of the Lassithi plateau, Dikti range, East Crete. The species was reported as Gynotyphlus sp. by Assing (2018b). The specimens were collected from soil in a ruderal dry temporary stream valley with Platanus orientalis, other deciduous trees, and Rubus undergrowth at an altitude of $850 \mathrm{~m}$. When sampling the locality the first time in December 2017, only two females were found. Washing a significantly larger amount of soil (approximately five times as much as the first time) in March 2018 produced only a single specimen, fortunately a male. Another attempt at finding the species in the same locality in December 2018 yielded a single female. It is currently unclear if such a rarity is a seasonal phenomenon or if the species lives in very deep soil layers and is consequently collected only accidentally.

\section{Cretotyphlus idanus Assing spec. nov.} urn:Isid:zoobank.org:act:993DEFB4-903E-4367-96DD-6F4D8F0DE42F (Figs 81-85, 175)

Type material: Holotype $0^{\top}$ : “GR - Crete [15], Psiloritis

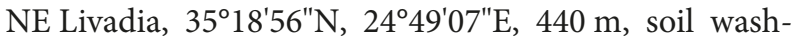
ing near stream, 26.XII.2018, V. Assing / Holotypus o Cretotyphlus idanus sp. n. det. V. Assing 2019” (cAss). Paratypes: $2 o^{\pi} o^{x}$ : same data as holotype (cAss).

Etymology: The specific epithet is an adjective derived from Ida, one of the names of the mountain range where the type locality is situated.

Description: Length of forebody approximately $0.6 \mathrm{~mm}$. Habitus as in Fig. 81. Colour of body dark-yellowish. Head with sparse punctation and with very shallow microreticulation. Pronotum approximately as long as broad and as broad as head; dorsal surface very smooth, with extremely fine, barely visible punctation and with shallow microreticulation.

Elytra with shallow traces of microsculpture and with sparse, extremely fine punctation barely visible even at a magnification of $150 \mathrm{x}$.

Abdomen with shallow microsculpture composed of large meshes; punctation extremely fine and moderately dense; pubescence long, pale, depressed, and moderately dense.

$0^{*}$ : sternites V-VIII each with an extensive median impression (Fig. 82); sternite VIII (Fig. 85) transverse and symmetric, with a pair of pronounced clusters of strongly modified, short and stout setae in median impression, posterior margin with nearly semicircular median excision; aedeagus $0.21 \mathrm{~mm}$ long and shaped as in Figs 83-84. o: : unknown.

Comparative notes: Cretotyphlus idanus is distinguished from $C$. hamatus by a slightly more robust body, extremely fine punctation of the pronotum, as well as by the completely different shape and chaetotaxy of the male sternite VIII and by the differently shaped and much smaller aedeagus.

Distribution and natural history: The type locality is situated near Livadia in the north slopes of the Psiloritis range, Central Crete. The specimens were found by washing soil near a stream in a stream valley with Platanus orientalis, Quercus sp., and undergrowth at an altitude of $440 \mathrm{~m}$ (Fig. 175). Sampling the locality a year earlier had not produced any specimens.

\section{Cretotyphlus chanianus Assing spec. nov. urn:Isid:zoobank.org:act:1D048CF4-D0DE-4839-869F-4D96B269F25C (Figs 86-91, 174)}

Type material: Holotype $0^{\star}:$ "GR - Crete [10], SW

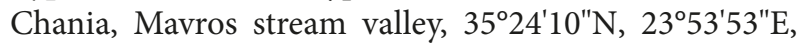
290 m, 24.XII.2018, V. Assing / Holotypus o Cretotyphlus chanianus sp. n. det. V. Assing 2019" (cAss). Paratypes: 1 ㅇ: same data as holotype (cAss); 1 ㅇ: "GR Crete [7], SW Chania, Mavros stream valley, 35²4'10"N, 2353'53"E, 290 m, 18.III.2018, V. Assing" (cAss).

Etymology: The specific epithet is an adjective derived from Chania, the region where the type locality is situated.

Description: Length of forebody $0.45-0.50 \mathrm{~mm}$. Habitus as in Fig. 86. Colour of body dark-yellowish.

Head with rather coarse punctation and with distinct microsculpture; ventral aspect as in Fig. 87. Pronotum approximately as long as broad and slightly broader than head; dorsal surface with rather coarse punctation and distinct microsculpture. Elytra without microsculpture and with sparse and fine punctation.

Abdomen only with shallow and indistinct traces of microsculpture; punctation extremely fine and moderately dense; pubescence moderately long, pale, depressed, and moderately dense.

$\mathrm{o}^{\star}$ : sternites VI-VIII each with an extensive median impression; sternite VIII (Fig. 88) approximately as long as broad, median impression with a pair of clusters of moderately dense and moderately modified setae in the middle and with very short setae in postero-median portion, posterior margin with broad, shallow, and slightly asymmetric concavity; aedeagus $0.24 \mathrm{~mm}$ long and shaped as in Figs 89-90.

: posterior margin of sternite VIII acutely produced in the middle; abdominal segments IX-X as in Fig. 91.

Comparative notes: Cretotyphlus chanianus is distinguished from C. hamatus and C. idanus by much coarser punctation of the head and pronotum, smaller size, shorter and more compact antennae with more transverse antennomeres, by the completely different shape and chaetotaxy of the male sternite VIII, and by the completely different shape of the aedeagus. 
Distribution and natural history: The type locality is situated to the southwest of Chania, West Crete. The specimens were washed from soil in a deep stream valley with Platanus orientalis and Rubus undergrowth at an altitude of $290 \mathrm{~m}$ (Fig. 174).

\section{Paederinae \\ Pseudobium creticum Assing spec. nov. urn:Isid:zoobank.org:act:98EA1ABE-EA17-4F90-A7BF-6069D9FDF481 (Figs 92-96)}

Type material: Holotype $0^{\star}$ : "GR - Crete [61], WSW Ag. Nikolaos, Katharo plateau, 1110 m, stream, $35^{\circ} 08^{\prime} 14^{\prime \prime} \mathrm{N}, 25^{\circ} 34^{\prime} 15^{\prime \prime} \mathrm{E}, 28$. III.2018, V. Assing / Holotypus o Pseudobium creticum sp. n. det. V. Assing 2018" (cAss). Paratypes: $20^{\top} o^{\top}, 5$ 우: same data as holotype (cAss); 5 우 ㅇ: "GR - Crete [12], WSW Ag. Nikolaos, Katharo plateau, 1110 m, stream, $35^{\circ} 08^{\prime} 14^{\prime \prime} \mathrm{N}, 25^{\circ} 34^{\prime} 15^{\prime \prime}$, 10.IV.2014, V. Assing” (cAss); 3 우: same data, but leg. Wunderle (cWun).

Etymology: The specific epithet is an adjective derived from Crete.

Description: Body length 4.2-5.4 mm; length of forebody 2.4-2.6 mm. Habitus as in Fig. 92. Coloration: body black with the posterior margin and often also the posterior portion of the suture of the elytra and the posterior portion of abdominal segment VIII yellowish to reddish; legs bicoloured with the femora blackish-brown and the tibiae and tarsi yellowish to dark-yellowish; antennae and maxillary palpi reddish.

Head (Fig. 93) approximately 1.3 times as long as broad; punctation rather coarse and dense, sparse in median dorsal portion; interstices without microsculpture. Eyes large, approximately 0.7 times as long as postocular portion in dorsal view. Antenna approximately $1.5 \mathrm{~mm}$ long; antennomeres IV approximately 1.5 times as long as broad, V-X decreasingly oblong, and X weakly oblong.

Pronotum (Fig. 93) 1.55-1.60 times as long as broad and $0.85-0.90$ times as broad as head; median portion broadly impunctate, delimited by a dorsal series of approximately 15 punctures on either side; punctation of lateral portions similar to that of head; interstices without microsculpture.

Elytra (Fig. 93) 1.05-1.10 times as long as pronotum; punctation rather coarse (similar to that of head and pronotum), dense, and seriate; interstices without microsculpture. Hind wings fully developed.

Abdomen slightly narrower than elytra, broadest at segment VII; punctation fine and rather dense; interstices with shallow microsculpture composed of irregular transverse meshes, this microsculpture more distinct on posterior than on anterior tergites; posterior margin of tergite VII with palisade fringe; posterior margin of tergite VIII strongly convex.
$0^{*}$ : sternite VII with weakly concave posterior margin, otherwise unmodified; posterior excision of sternite VIII small and not very deep (Fig. 94); median lobe of aedeagus approximately $0.5 \mathrm{~mm}$ long, with slender and sinuately spine-shaped ventral process and with dorsal plate of derived shape (Figs 95-96).

Comparative notes: In external characters, P. creticum is most similar to P. hellenicum Assing, 2006, presumably its closest relative, as is suggested by the similarly derived shape of the dorsal plate of the aedeagus. It differs from this species by the posteriorly less extensively yellowish elytra and by the differently shaped aedeagus, especially the much longer and more slender ventral process. The shape of the ventral process of the aedeagus somewhat resembles that of P. anatolicum Assing, 2006, from which P. creticum is distinguished by paler antennae and tibiae, darker and shorter elytra with more distinct and less dense punctation, smaller body size, and by the completely different shape of the dorsal plate of the aedeagus. For illustrations of $P$. hellenicum and P. anatolicum see Assing (2006b).

Distribution and natural history: The absence of records from mainland Greece and Turkey, as well as from other East Mediterranean islands suggests that P. creticum is endemic to Crete. The type locality is situated in the Katharo plateau in the Dikti range, to the southwest of Agios Nikolaos, East Crete. The female paratypes collected in 2014 were reported as P. hellenicum by Assing (2015). The specimens were floated from gravel on the banks of a small stream surrounded by cultivated land at an altitude of $1110 \mathrm{~m}$. The sex ratio appears to be remarkably biased: all eight specimens collected in 2014 and five of the eight specimens found in 2018 are females.

\section{Staphylininae}

\section{Gabrius candicus Assing spec. nov.} urn:Isid:zoobank.org:act:4FACOFC1-20F7-4DC4-BAA9-FBC4DDF3175D (Figs 97-101)

Type material: Holotype $\sigma^{*}$ : "GR - Crete [4a], S Kissa-

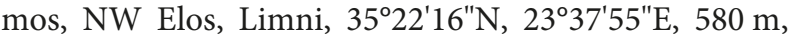
pond margin, 23.XII.2018, V. Assing / Holotypus $0^{*}$ Gabrius candicus sp. n. det. V. Assing 2019" (cAss). Paratypes: $11 \sigma^{*} \sigma^{*}, 6$ 우 9 : same data as holotype (cAss, cFel, NHMW); $4 o^{\top} o^{\star}, 4$ ㅇ ㅇ: “N3522'17 E2337'57, GR Westkreta, Limni 590 m, 20.3.2019, Brachat \& Meybohm (12)" (cAss).

Etymology: The specific epithet is an adjective derived from Candia, the Venetian name for Crete.

Description: Body length $4.2-6.0 \mathrm{~mm}$ (measured to posterior margin of tergite VIII); length of forebody 2.4-2.9 mm. Habitus as in Fig. 97. Coloration: body 
black, except for the partly dark-yellowish abdominal segments VIII-X; legs dark-yellowish with the femora and tibiae partly infuscate; antennae blackish with (parts of) antennomere I, the base of antennomere II, and often also the base of antennomere III paler.

Head without sexual dimorphism, approximately 1.15 times as long as broad, lateral margins behind eyes usually weakly converging in dorsal view; dorsal surface with fine microsculpture. Eyes more or less distinctly shorter than postocular region in dorsal view. punctation rather coarse and dense, sparse in median dorsal portion; interstices without microsculpture. Eyes large, approximately 0.7 times as long as postocular portion in dorsal view. Antenna 1.3-1.4 mm long; preapical antennomeres weakly transverse.

Pronotum approximately 1.25 times as long as broad and 1.15 times as broad as head; dorsal series composed of $1+5$ punctures; disc with nearly obsolete to distinct transverse microsculpture.

Elytra approximately 0.7 times as long as pronotum; punctation moderately dense and moderately coarse; interstices without microsculpture. Hind wings fully developed.

Abdomen with dense and fine punctation, the density gradually decreasing from anterior towards posterior tergites; interstices with very fine and shallow transverse microsculpture visible only at high magnification; posterior margin of tergite VII with palisade fringe.

$\mathrm{o}^{\star}$ : sternite VIII (Fig. 100) posteriorly membranous, with shallowly concave posterior excision, and with long setae and longitudinal sculpture in posterior third; aedeagus (Figs 98-99) 1.00-1.05 mm long and of highly distinctive shape.

o : terminalia as in Fig. 101.

Comparative notes: Based on external and the male sexual characters, $G$. candicus belongs to the G. nigritulus group. It is easily distinguished from other representatives of this group only by the male sexual characters, particularly the conspicuous shape of the aedeagus. It is additionally distinguished from the similar G. nigritulus (Gravenhorst, 1802), the only other Gabrius species known from Crete, by more distinctly infuscate femora and tibiae, a posteriorly usually tapering head, on average larger eyes, less pronounced microsculpture on the abdomen, and by a posteriorly more acute female tergite IX with more numerous long apical setae.

Distribution and natural history: The type locality is situated to the south of Kissamos in West Crete. The specimens were sifted from debris and grass roots at the margin of an artificial pond at an altitude of $580 \mathrm{~m}$. The species is most likely endemic in Crete and was probably widespread in the island. The fact that it had never been recorded before suggests that it is very rare today, presumably because suitable habitats (natural lakes, ponds, swamps) have almost completely disappeared as a result of extensive agricultural and other human activity.

\section{Scydmaeninae}

\section{Genus Cephennium MüLleR \& Kunze, 1822}

The speciose genus Cephennium is distributed in the West Palaearctic region eastwards to Middle Asia and included nearly 150 species and several subspecies assigned to six subgenera; for the species known at the end of 2014 see Schülke and Smetana (2015). According to JALOSZYŃsKi \& STEVANOvić (2015), who also illustrate the general distribution of the genus known at present, the current subgeneric concept is problematic and largely artificial. Most Cephennium species are locally endemic. Not a single species had been reported from Crete.

Recent field trips to Crete have yielded a substantial number of Cephennium specimens, the vast majority of them collected by washing soil in winter and early spring, suggesting an essentially subterranean habitat. An examination of the material collected with males revealed that they belong to twelve species, all of which are described below. Some additional females remain unnamed for the time being. They may represent additional species, but since the aedeagus is indispensable for a reliable identification, their identity requires clarification based on males. In view of the problematic subgeneric concept currently in use, none of the newly described species is assigned to one of the existing subgenera. All Cretan Cephennium species are anophthalmous or microphthalmous, apterous, and weakly pigmented.

Based on external characters and on the morphology of the aedeagus, the Cretan species are assigned to three species groups, the C. arcuatum group, the C. sinuosum group, and the $C$. chanianum group.

The C. arcuatum group includes five species, two (C. selinonum, C. meybohmi) from West Crete, one (C. idanum) from Central Crete, and two (C. arcuatum, C. thripticum) from East Crete. They are characterized by intermediate body size, a distinctly oblong antennomere XI (approximately 1.5 times as long as broad), eye rudiments with one to five weakly defined ommatidia without pigmentation, a pronotum with fine, but distinct punctation at least in posterior portion (where it is more distinct than that of elytra), elytra with a pronounced antero-lateral fold (process) and with a rather distinct and long humeral sulcus (fold), and an aedeagus with a short and apically smoothly convex ventral process (ventral view). Cephennium kerpense Меувонм, 2016 from Karpathos probably belongs to this group, too, but is distinguished from the Cretan representatives by the shape of the apical margin of the ventral process of the aedeagus (not smoothly convex in ventral view). Females representing one to three additional species from West and East Crete remain undescribed for want of males.

The C. sinuosum group includes six species from East and Central Crete (C. sinuosum, C. fortespinosum, C. hamulatum, C. curvatum, C. selenanum, C. latius). They are distinguished from the otherwise similar species of the C. arcuatum group by a short, conical, and weakly oblong 
antennomere XI, completely reduced eyes (ommatidia absent), extremely fine punctation of the pronotum, elytra with a weakly pronounced antero-lateral fold (process) and a fine humeral sulcus, and an aedeagus with a mostly longer and apically pointed ventral process (ventral view), and with a sclerotized ring-shaped basodorsal internal structure.

The C.chanianum group includes only C. chanianum from West Crete. It is characterized by larger body size, relatively long antennae with a distinctly oblong antennomere XI, completely reduced eyes (ommatidia absent), an anteriorly strongly dilated pronotum, extremely fine pronotal punctation, elytra with a somewhat obtuse antero-lateral fold and with a distinct humeral sulcus (fold), and a relatively large aedeagus with a rather long, slender, and sinuate (lateral view) ventral process and with large and strongly sclerotized internal structures.

\section{Cephennium arcuatum group}

\section{Cephennium arcuatum Assing spec. nov. urn:Isid:zoobank.org:act:7A3212BC-0311-49F7-A2AB-C529B6CD42A9 (Figs 102-103)}

Type material: Holotype $\sigma^{\star}$ : "GR - Crete [24], SW Malia, SW Gonies, $35^{\circ} 12^{\prime} 38^{\prime \prime} \mathrm{N}, 25^{\circ} 26^{\prime} 42^{\prime \prime} \mathrm{E}, 510 \mathrm{~m}$, soil washing, 1.I.2018, V. Assing / Holotypus o Cephennium arcuatum sp.n. det. V. Assing 2018" (cAss). Paratype + : "GR - Crete [26], SW Malia, Gonies env., 35¹4'09"N, $25^{\circ} 26^{\prime} 37^{\prime E} \mathrm{E}, 290 \mathrm{~m}$, soil washing, 1.I.2018, V. Assing” (cAss).

Etymology: The specific epithet (Latin, adjective: bent, shaped like a bow) alludes to one of the apical internal structures of the aedeagus, which somewhat resembles a coat hanger.

Description: Body length $1.0 \mathrm{~mm}$; width of pronotum $0.38-0.39 \mathrm{~mm}$; width of elytra $0.42 \mathrm{~mm}$. Habitus as in Fig. 102. Coloration: body yellowish-red; legs, antennae, and maxillary palpi yellow. Eyes reduced, composed of approximately five ommatidia without pigmentation. Head, pronotum, and elytra without microsculpture. Pubescence very sparse on head and rather dense on pronotum and elytra, moderately long, suberect, pale, and directed predominantly posteriad on head, elytra, and most of pronotum, obliquely postero-mediad in postero-lateral portions and at posterior margin of pronotum. Punctation of head and elytra extremely fine, barely noticeable at a magnification of $150 \mathrm{x}$, that of pronotum fine, but more distinct than that of elytra; median portion of head impunctate. Tibiae moderately clubshaped, dilated in distal two-thirds. Antenna $0.4 \mathrm{~mm}$ long, with distinct club formed by the large antennomeres IX-XI; antennomere VIII much smaller than the neighbouring antennomeres VII and IX; antennomere XI approximately 1.5 times as long as broad. Pronotum distinctly transverse, nearly 1.2 times as broad as long. Elytra basally with a pronounced antero-lateral process or fold and with a distinct oblique humeral sulcus or fold, respectively, on either side.

$\sigma^{*}$ : aedeagus $0.26 \mathrm{~mm}$ long; ventral process apically convex in ventral view; internal sac with sclerotized structures of distinctive shapes (Fig. 103).

Comparative notes: Cephennium arcuatum is reliably distinguished from other Cretan congeners by the shape and internal structures of the aedeagus.

Distribution and natural history: The known distribution is confined to the environs of Gonies to the Southwest of Malia, East Crete. The holotype was collected in a steep rocky slope with Quercus ilex at an altitude of $510 \mathrm{~m}$, the paratype in a dry ruderal stream valley with Platanus orientalis, olive trees, and undergrowth at an altitude of $290 \mathrm{~m}$, both of them by washing soil.

\section{Cephennium thripticum Assing spec. nov. urn:Isid:zoobank.org:act:6681B4E6-3602-47F6-82BF-C1C9FD0E6A45 (Figs 104-105)}

Type material: Holotype $0^{\star}$ : “GR - Crete [5a], Orno Thriptis, SE Thripti, $1130 \mathrm{~m}$, soil, 350ㅗ'16"N, 2552'58"E 25.XII.2017, V. Assing / Holotypus ơ Cephennium thripticum sp. n. det. V. Assing 2018" (cAss). Paratypes: $10^{\star}$,

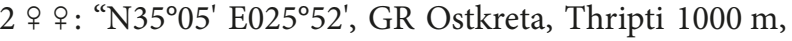
Meybohm 11.3.2001" (cMey).

Etymology: The specific epithet is an adjective derived from Thripti, the name of the mountain where this species is probably endemic.

Description: Body length $0.95-1.0 \mathrm{~mm}$; width of pronotum $0.38 \mathrm{~mm}$; width of elytra $0.42 \mathrm{~mm}$. Coloration: body yellowish-red; legs, antennae, and maxillary palpi yellow. Eyes reduced, composed of approximately five ommatidia without pigmentation. Head, pronotum, and elytra without microsculpture. Pubescence very sparse on head and rather dense on pronotum and elytra, moderately long, suberect, pale, and directed predominantly mediad on head, posteriad on elytra and most of pronotum, obliquely postero-mediad in postero-lateral portions and at posterior margin of pronotum. Punctation of head and elytra extremely fine, barely noticeable at a magnification of $150 \mathrm{x}$, that of pronotum more distinct; median portion of head impunctate. Tibiae moderately club-shaped, dilated in distal two-thirds. Antenna $0.45 \mathrm{~mm}$ long, with distinct club formed by the large antennomeres IX-XI; antennomere VIII much smaller than the neighbouring antennomeres VII and IX; antennomere XI nearly twice as long as broad. Pronotum distinctly transverse, approximately 1.2 times as broad as long. Elytra with a pronounced antero-lateral process and with a distinct oblique humeral fold/sulcus on either side. 
$\sigma^{*}$ : aedeagus $0.23 \mathrm{~mm}$ long; ventral process short, apically convex in ventral view; internal sac with sclerotized structures of distinctive shapes (Figs 104-105).

Comparative notes: Cephennium thripticum is reliably distinguished from other Cretan congeners of the C. arcuatum group only by the shape and internal structures of the aedeagus.

Distribution and natural history: The type specimens were found in two geographically close localities in the Orno Thriptis in the extreme east of Crete at altitudes of 1000 and $1130 \mathrm{~m}$. A female collected in the environs of Sfaka (near the coast north of Orno Thriptis) may belong to this species, too, but a male from this locality would be required to confirm this. The holotype was collected in a rocky slope with Quercus ilex by washing soil, the paratypes were sifted from litter.

\section{Cephennium selinonum Assing spec. nov. urn:Isid:zoobank.org:act:5C1D00CC-C8A3-4043-92A9-773137CD17CB (Figs 106-108)}

Type material: Holotype $\sigma^{\star}$ : "GR - Crete [50], E Kandanos, Anisaraki, $35^{\circ} 19^{\prime} 53^{\prime \prime} \mathrm{N}, 23^{\circ} 45^{\prime} 34^{\prime \prime E}, 560 \mathrm{~m}$, soil washing, 25.III.2018, V. Assing / Holotypus क Cephennium selinonum sp. n. det. V. Assing 2018” (cAss).

Etymology: The specific epithet is an adjective derived from Selino, the name of the district where the type locality is situated.

Description: Body length $0.95 \mathrm{~mm}$; width of pronotum $0.36 \mathrm{~mm}$; width of elytra $0.39 \mathrm{~mm}$. Habitus as in Fig. 106. Coloration: body pale-reddish; legs, antennae, and maxillary palpi yellow. Eyes reduced, composed of approximately five ommatidia without pigmentation. Head, pronotum, and elytra without microsculpture. Pubescence sparse, long, suberect, yellowish, and directed predominantly posteriad on head, elytra, and most of pronotum, denser and directed transversely mediad at posterior margin of pronotum. Punctation of head and elytra extremely fine, barely noticeable at a magnification of $150 \mathrm{x}$, that of pronotum distinct and moderately dense. Tibiae moderately club-shaped, dilated in distal twothirds. Antenna $0.4 \mathrm{~mm}$ long, with distinct club formed by the large antennomeres IX-XI; antennomere VIII much smaller than the neighbouring antennomeres VII and IX; antennomere XI approximately 1.5 times as long as broad. Pronotum distinctly transverse, approximately 1.2 times as broad as long. Elytra with a pronounced antero-lateral process and with a distinct oblique humeral fold on either side.

$\sigma^{*}$ : aedeagus small, $0.21 \mathrm{~mm}$ long; ventral process apically convex in ventral view, distinctly curved and acute in lateral view; internal sac with four sclerotized spines of subequal length (Figs 107-108).
Comparative notes: Cephennium selinonum is reliably distinguished from other species of the $C$. arcuatum group by the shape and internal structures of the aedeagus. It additionally differs from $C$. chanianum, its geographically closest congener, by smaller size, a less slender habitus, a more distinctly transverse, anteriorly less strongly broadened, and more distinctly punctate pronotum, much shorter antennae, and less distinctly club-shaped legs.

Distribution and natural history: The type locality is situated in the mountain range to the southeast of Kandanos, Southwest Crete. It is a ruderal habitat in the periphery of a village at the margin of an olive grove. The holotype was collected from soil beneath a very old Platanus orientalis tree at an altitude of $560 \mathrm{~m}$.

\section{Cephennium meybohmi Assing spec. nov. urn:Isid:zoobank.org:act:BDCAA375-E045-47F7-AC38-6812249B9A7C (Figs 109-110)}

Type material: Holotype $0^{\top}$ : “N35²3'54 E2354'38, GR Westkreta 440 m, Karanos W 31.3.2019, Brachat \& Meybohm (14) / Holotypus o Cephennium meybohmi sp. n. det. V. Assing 2019” (cAss).

Etymology: This species is dedicated to Heinrich Meybohm, specialist of Scydmaeninae, who discovered the holotype and granted permission to retain it.

Description: Body length $0.95 \mathrm{~mm}$; width of pronotum $0.38 \mathrm{~mm}$; width of elytra $0.40 \mathrm{~mm}$. Coloration: body pale-reddish; legs, antennae, and maxillary palpi yellow. Eyes reduced, composed of three ommatidia without pigmentation. Punctation of head and elytra extremely fine, barely noticeable at a magnification of $150 \mathrm{x}$, that of pronotum visible, but very fine in anterior three-fourths, more distinct only in posterior fourth. Tibiae moderately club-shaped, dilated in distal three-fifths. Other external characters as in C. selinonum.

$\mathrm{o}^{\star}$ : aedeagus $0.24 \mathrm{~mm}$ long; ventral process apically convex in ventral view, distinctly curved and acute in lateral view; internal sac with two pairs of large sclerotized spines and with numerous additional smaller spines (Figs 109-110).

Comparative notes: Cephennium meybohmi is reliably distinguished from other species of the C. arcuatum group by the shape and internal structures of the aedeagus. It differs from C. selinonum, the geographically closest congener of the C. arcuatum group, by less distinct punctation in the anterior three-fourths of the pronotum, the shape of the larger aedeagus in lateral view, and particularly by the presence of numerous smaller spines in the internal sac of the aedeagus.

Distribution and natural history: The type locality is situated near Karanos to the southwest of Chania. The 
holotype was collected by washing soil from a stream valley with Platanus orientalis at an altitude of $440 \mathrm{~m}$.

\section{Cephennium idanum Assing spec. nov. urn:Isid:zoobank.org:act:C7F685DD-32CC-4AF7-AA4E-4B3096D86B13 (Figs 111-113, 175)}

Type material: Holotype $\sigma^{*}$ : "GR - Crete [15], Psiloritis, NE Livadia, $35^{\circ} 18^{\prime} 56^{\prime \prime} \mathrm{N}, 24^{\circ} 49^{\prime} 07^{\prime \prime} \mathrm{E}, 440 \mathrm{~m}$, soil washing near stream 26.XII.2018, V. Assing / Holotypus ${ }^{*}$ Cephennium idanum sp. n. det. V. Assing 2019" (cAss). 2 우 우: “GR - Crete [21], Psiloritis NE Livadia, $35^{\circ} 18^{\prime} 56^{\prime \prime} \mathrm{N}, 24^{\circ} 49^{\prime} 07^{\prime \prime} \mathrm{E}, 440 \mathrm{~m}$, soil washing near stream, 31.XII.2017, V. Assing” (cAss); 1 ơ, 1 \%: “N35ำ18'56 E244'07, GR Kreta $440 \mathrm{~m}$, Livadia NE 18.3.2019, Brachat \& Meybohm (8)" (cMey).

Etymology: The specific epithet is an adjective derived from Ida, one of the names of the mountain range where the type locality is situated.

Description: Body length $1.00-1.05 \mathrm{~mm}$; width of pronotum $0.39-0.40 \mathrm{~mm}$; width of elytra $0.43-0.45 \mathrm{~mm}$. Coloration: body pale-reddish; legs, antennae, and maxillary palpi yellow. Eye rudiments present, with or without indistinct ommatidium. Head, pronotum, and elytra without microsculpture. Pubescence sparse, long, suberect, yellowish, and directed predominantly posteriad on head, elytra, and most of pronotum, denser and directed transversely mediad at posterior margin of pronotum. Punctation of head and elytra extremely fine, barely noticeable at a magnification of $150 \mathrm{x}$, that of pronotum distinct and moderately dense. Tibiae moderately club-shaped, dilated in distal two-thirds. Antenna $0.45 \mathrm{~mm}$ long, with distinct club formed by the large antennomeres IX-XI; antennomere VIII much smaller than the neighbouring antennomeres VII and IX; antennomere XI approximately 1.5 times as long as broad. Pronotum distinctly transverse, approximately 1.2 times as broad as long. Elytra with a pronounced antero-lateral process and with a distinct oblique humeral fold on either side.

$\sigma^{\star}$ : aedeagus $0.27 \mathrm{~mm}$ long, larger than in other species of the C. arcuatum group; ventral process apically convex in ventral view, basally convex and apically acute in lateral view; internal sac with conspicuous cluster of numerous strongly sclerotized spines (Figs 111-113).

Comparative notes: Like other species of the C. arcuatum group, C. idanum is reliably distinguished from other representatives of this group only by the shape and internal structures of the aedeagus.

Distribution and natural history: The type locality is situated in the north slopes of the Psiloritis range, Central Crete, where C. idanum is currently the sole representative of the C. arcuatum group. The specimens were collected by soil washing in a stream valley with large rocks and with Platanus orientalis, Quercus sp., and undergrowth at an altitude of $440 \mathrm{~m}$ (Fig. 175).

\section{Cephennium spec.}

Material examined: $2 \circ+$, Chania, Samaria gorge, 28.III.1983, leg. Brachat \& Dörnfeld (cAss); 1 우, Chania, Omalos-Samaria, 20.V.1980, leg. Brachat (cAss).

The above females belong to a - most likely undescribed - species of the C. arcuatum group.

\section{Cephennium spec.}

Material examined: 1 ㅇ, ca. $20 \mathrm{~km}$ E Agios Nikolaos, Sfaka, $35^{\circ} 09^{\prime} 00^{\prime \prime} \mathrm{N}, 25^{\circ} 55^{\prime} 26^{\prime \prime} \mathrm{E}, 320 \mathrm{~m}$, soil washing, 24.XII.2017, leg. Assing (cAss); 1 , SW Agios Nikolaos,

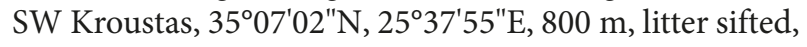
12.III.2018, leg. Brachat \& Meybohm (cAss).

The above females most likely represent at least one undescribed species of the C. arcuatum group.

\section{Cephennium sinuosum group}

\section{Cephennium sinuosum Assing spec. nov. urn:Isid:zoobank.org:act:C89E57D1-33EB-4693-BF85-27EAC289A064 (Figs 114-117)}

Type material: Holotype $0^{\star}$ : "GR - Crete [20], SW Sitia, W Achladia, 3509' $45^{\prime \prime} \mathrm{N}, 26^{\circ} 02^{\prime} 26^{\prime \prime E}, 270 \mathrm{~m}$, soil washing, 30.XII.2017, V. Assing / Holotypus o Cephennium sinuosum sp. n. det. V. Assing 2018” (cAss). Paratypes: $2 \sigma^{\top} o^{\top}, 4$ 우 온 same data as holotype (cAss); 1 ㅇ: "GR Crete [18], SW Sitia, NW Makrigialos, 3503'31"N, 2556'49"E $70 \mathrm{~m}$, soil washing, 30.XII.2017, V. Assing" (cAss); 1 o $^{\star}$ : "GR - Crete [25], SW Malia, Gonies env., $35^{\circ} 14^{\prime} 43^{\prime \prime} \mathrm{N}, 25^{\circ} 25^{\prime} 34^{\prime \prime} \mathrm{E}, 220 \mathrm{~m}$, soil washing, 1.I.2018, V. Assing" (cAss) (cAss).

Etymology: The specific epithet (Latin, adjective) alludes to the distinctly sinuate internal spines of the aedeagus.

Description: Body length $0.92-0.99 \mathrm{~mm}$; width of pronotum $0.37-0.39 \mathrm{~mm}$; width of elytra $0.39-0.40 \mathrm{~mm}$. Habitus as in Fig. 114. Coloration: body yellowish-red; legs, antennae, and maxillary palpi yellow. Eyes completely absent. Head, pronotum, and elytra without microsculpture. Pubescence very sparse on head and rather dense on pronotum and elytra, rather short on elytra and most of pronotum, long and very dense at and near posterior margin of pronotum, depressed to weakly suberect, pale, and directed posteriad on elytra and most of pronotum, transversely mediad at posterior margin of pronotum. 
Punctation of head, pronotum, and elytra extremely fine, that of pronotum not more distinct than that of elytra; median portion of head impunctate. Tibiae distinctly club-shaped, rather abruptly dilated in distal two-thirds. Antenna $0.39-0.43 \mathrm{~mm}$ long, with distinct club formed by the large antennomeres IX-XI; antennomere VIII much smaller than the neighbouring antennomeres VII and IX; antennomere XI broadly conical, weakly oblong. Pronotum distinctly transverse, approximately 1.2 times as broad as long. Elytra with a rather weakly pronounced antero-lateral fold and with a fine oblique humeral fold on either side.

$\mathrm{o}^{\star}$ : aedeagus $0.25 \mathrm{~mm}$ long; ventral process blade-shaped and apically acute in ventral view; internal sac with two pairs of partly strongly sinuate sclerotized spines (Figs 115-117).

Comparative notes: Cephennium sinuosum is reliably distinguished from other species of the C. sinuosum group only by the shape and internal structures of the smaller aedeagus.

Distribution and natural history: This species is reliably known from two localities in the extreme east of Crete. The record of the male from the environs of Gonies (SW Malia) is regarded as doubtful and requires confirmation; it may be based on an artefact in the extraction procedure. The specimens were found in a valley with a small temporary stream and vegetation composed of Platanus orientalis, bushes, undergrowth, and reed, and in a dry stream valley with old oak and other deciduous trees and undergrowth. All of them were collected by soil washing. The altitudes range from 70 to $270 \mathrm{~m}$.

\section{Cephennium fortespinosum Assing spec. nov. urn:Isid:zoobank.org:act:C84F5038-F12C-48CC-9ED7-8DBE6BAE1D5C (Figs 118-119)}

Type material: Holotype $\sigma^{\star}$ : “N3506'57 E26¹3'10, GR Ostkreta Ano Zakros 14.3.2019, Brachat \& Meybohm (1) / Holotypus o Cephennium fortespinosum sp. n. det. V. Assing 2019” (cAss). Paratypes: 3 우 우 "GR - Crete [16], Zakros, 3506'57"N, 26¹3'10"E, 190 m, dry stream valley, soil washing, 27.XII.2018, V. Assing” (cAss).

Etymology: The specific epithet (Latin, adjective) alludes to the massive spines in the internal sac of the aedeagus.

Description: External characters as in C. sinuosum; distinguished only by the male primary sexual characters.

$\sigma^{*}$ : aedeagus $0.27 \mathrm{~mm}$ long; ventral process much broader, shorter, and apically less acute in ventral view, stouter in lateral view; internal sac with a long and massive median spine and with three pairs of lateral spines (Figs 118-119).
Comparative notes: Cephennium fortespinosum is reliably distinguished from C. sinuosum and other species of the C. sinuosum group only by the shape and internal structures of the aedeagus.

Distribution and natural history: The type locality is situated immediately north of Zakros in the extreme east on Crete. The specimens were washed from soil taken in the stream valley with Platanus orientalis at an altitude of $190 \mathrm{~m}$.

\section{Cephennium hamulatum Assing spec. nov. urn:Isid:zoobank.org:act:FA4D9AB5-DAA3-4DE7-8064-5B98210F93D0 (Figs 120-121)}

Type material: Holotype $0^{*}$ : "GR - Crete [14], S Kritsa, $35^{\circ} 08^{\prime} 44^{\prime \prime} \mathrm{N}, 25^{\circ} 38^{\prime} 29^{\prime \prime E}, 420 \mathrm{~m}$, soil washing, 27.XII.2017, V. Assing / Holotypus o Cephennium hamulatum sp. n. det. V. Assing 2018" (cAss). Paratypes: $1 \sigma^{*}, 7$ 우 : same data as holotype (cAss); 1 o $^{\text {, }} 1$ ㅇ: "GR - Crete [13], S Kritsa, $35^{\circ} 08^{\prime} 47^{\prime \prime N}, 25^{\circ} 38^{\prime} 24^{\prime \prime E}, 400 \mathrm{~m}$, soil washing, 27.XII.2017, V. Assing” (cAss); 3 o $^{\top} 0^{\top}, 1$ 우: “N35 $08^{\circ} 45$ E2538'30, GR Lassithi (5), Kritsa s 390 m 11.3.2018, 1. Brachat \& Meybohm" (cMey).

Etymology: The specific epithet is an adjective derived from the Latin noun hamulus (small hook) and alludes to the minute lateral hook on one of the pairs of sclerotized internal spines of the aedeagus.

Description: Body length $0.83-0.90 \mathrm{~mm}$; width of pronotum $0.32-0.35 \mathrm{~mm}$; width of elytra $0.35-0.38 \mathrm{~mm}$; length of antenna $0.33-0.35 \mathrm{~mm}$. Other external characters as in C. sinuosum.

$\mathrm{o}^{*}$ : aedeagus $0.28-0.29 \mathrm{~mm}$ long; ventral process bladeshaped and apically acute in ventral view; internal sac with three pairs of long sclerotized spines of distinctive shapes, the lateral spines (ventral view) with a small hook (Figs 120-121).

Comparative notes: Based on the similar external morphology and on the similar general structure of the aedeagus, C. hamulatum is undoubtedly closely allied to C. sinuosum, from which it differs by smaller size (no overlap; see measurements) and by the shape of the aedeagus and its internal structures.

Distribution and natural history: The type specimens were found in two geographically close localities to the south of Kritsa, East Crete. They were collected in dry rocky stream valleys with Quercus ilex at altitudes of 400 to $420 \mathrm{~m}$, mostly by washing soil. Four specimens were sifted from leaf litter. 
Cephennium curvatum Assing spec. nov. urn:Isid:zoobank.org:act:73B78F2A-4907-4334-B475-A59C7CD81063 (Fig. 122)

Type material: Holotype $0^{*}$ : "GR - Crete [2], ca $20 \mathrm{~km}$ E Ag. Nikolaos, Sfaka, 3509'00"N, 2555'26"E, 320 m, soil washing, 24.XII.2017, V. Assing / Holotypus o Cephennium curvatum sp. n. det. V. Assing 2018” (cAss).

Etymology: The specific epithet (Latin, adjective) alludes to the shapes of one of the pairs of internal structures of the aedeagus.

Description: Body length $1.0 \mathrm{~mm}$; width of pronotum $0.36 \mathrm{~mm}$; width of elytra $0.39 \mathrm{~mm}$. Coloration: body yellowish-red; legs, antennae, and maxillary palpi yellow. Other external characters as in C. sinuosum and C. hamulatum.

$\sigma^{\star}$ : aedeagus $0.32 \mathrm{~mm}$ long; ventral process apically elongated and acute in ventral view; internal sac with two pairs of sclerotized spines, two of them strongly curved (Fig. 122).

Comparative notes: Aside from the shapes of the median lobe and the internal structures of the aedeagus, C. curvatum differs from the closely allied C. hamulatum and C. sinuosum only by a slightly more slender habitus, from C. hamulatum also by larger size (see measurements). The aedeagus is larger than in all the other named species of the C. sinuosum group, except C. selenanum.

Distribution and natural history: The holotype was collected near Sfaka, East Crete, in a dry stream valley with Quercus ilex and olive trees at an altitude of $320 \mathrm{~m}$ by washing soil.

\section{Cephennium selenanum Assing spec. nov. urn:Isid:zoobank.org:act:E5B87D2D-9402-43F9-82E3-1DEF6D709DF1 (Figs 123-124)}

Type material: Holotype $o^{\star}$ : “GR - Crete [28], SE Malia, Selena Oros, $35^{\circ} 14^{\prime} 40^{\prime \prime} \mathrm{N}, 25^{\circ} 31^{\prime} 03^{\prime \prime E}, 880 \mathrm{~m}$, sifted, 2.I.2018, V. Assing / Holotypus o Cephennium selenanum sp. n. det. V. Assing 2018" (cAss). Paratype + : same data, but soil washing, 26.III.2018 (cAss).

Etymology: The specific epithet is an adjective derived from the name of the mountain (Selena Oros) where the type locality is situated.

Description: Body length $0.95 \mathrm{~mm}$; width of pronotum $0.35 \mathrm{~mm}$; width of elytra $0.38 \mathrm{~mm}$; length of antenna $0.36 \mathrm{~mm}$. Other external characters as in C. sinuosum, C. hamulatum, and C. curvatum. $\sigma^{*}$ : aedeagus $0.31 \mathrm{~mm}$ long; ventral process of triangular shape in ventral view; internal sac with six long thin sclerotized spines (Figs 123-124).

Comparative notes: This species is distinguished from C. hamulatum, C. sinuosum, and C.curvatum by the shape and internal structures of the aedeagus, from C. sinuosum also by smaller size.

Distribution and natural history: The type locality is situated in Selena Oros to the Southeast of Malia. The holotype was sifted from litter, roots, and moss in a calcareous north slope with Quercus ilex at an altitude of $880 \mathrm{~m}$. The paratype was collected in the same locality by washing soil.

\section{Cephennium latius Assing spec. nov.}

urn:Isid:zoobank.org:act:8B3A0458-1D50-4551-BED6-D307750DD522

(Figs 125-126, 175)

Type material: Holotype $\sigma^{*}$ : "GR - Crete [15], Psiloritis, NE Livadia, $35^{\circ} 18^{\prime} 56^{\prime \prime} \mathrm{N}, 24^{\circ} 49^{\prime} 07^{\prime \prime} \mathrm{E}, 440 \mathrm{~m}$, soil washing near stream 26.XII.2018, V. Assing / Holotypus o Cephennium latius sp. n. det. V. Assing 2019” (cAss).

Etymology: The specific epithet is the comparative of the Latin adjective latum (broad, wide) and alludes to the broad ventral process of the aedeagus, one of the characters distinguishing this species from other representatives of the C. sinuosum group.

Description: Body length $1.0 \mathrm{~mm}$; width of pronotum $0.36 \mathrm{~mm}$; width of elytra $0.40 \mathrm{~mm}$; length of antenna $0.45 \mathrm{~mm}$. Other external characters as in C. sinuosum, C. hamulatum, and C. selenanum.

$\sigma^{*}$ : aedeagus $0.30 \mathrm{~mm}$ long; ventral process somewhat resembling a house in cross-section in ventral view; internal sac with sclerotized spines of distinctive shapes (Figs 125-126).

Comparative notes: This species is distinguished from C. hamulatum, C. sinuosum, and C. curvatum by longer antennae and the shape and internal structures of the aedeagus.

Distribution and natural history: The type locality (Fig. 175) is identical to that of C.idanum and Cretotyphlus idanus.

\section{Cephennium chanianum group \\ Cephennium chanianum Assing spec. nov. urn:Isid:zoobank.org:act:0C990A58-8107-4B07-87D5-FE0541CD444 (Figs 127-129)}

Type material: Holotype $\sigma^{\star}$ : "GR - Crete [17], S Kissa-

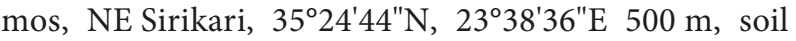


washing, 19.III.2018, V. Assing / Holotypus ot Cephennium chanianum sp. n. det. V. Assing 2018" (cAss). Paratypes: 1 ㅇ: "GR - Crete [14], S Kissamos, Aikirgianis, $35^{\circ} 25^{\prime} 45^{\prime \prime} \mathrm{N}, 23^{\circ} 40^{\prime} 36^{\prime \prime} \mathrm{E}, 290 \mathrm{~m}$, soil washing, 19.III.2018, V. Assing” (cAss); 1 : “GR - Crete [20],
S Kissamos, W Sirikari, 3524'32"N, 2337'37"E, 500 m, soil washing, 19.III.2018, V. Assing" (cAss); $1 \mathrm{o}^{\star}$ : "GR - Crete [25], SW Chania, SW Prases, 35²1'43"N, $23^{\circ} 49^{\prime} 24 " \mathrm{E}, 640 \mathrm{~m}$, soil washing, 20.III.2018, V. Assing” (cAss); 1 ㅇ: "GR - Crete [7], SW Chania, Mavros stream

\section{Key to the Cephennium species of Crete}

1. Slightly larger species: body length $>1.0 \mathrm{~mm}$; width of elytra $>0.43 \mathrm{~mm}$. Pronotum more strongly dilated in anterior half (Fig. 127). Eyes completely absent. Aedeagus of distinctive shape (Figs 128-129). West Crete. chanianum

- Smaller species: body length $\leq 1.0 \mathrm{~mm}$; width of elytra $\leq 0.42 \mathrm{~mm}$. Pronotum weakly dilated in anterior half. Aedeagus of completely different morphology

2. Antennomere XI at least approximately 1.5 times as long as broad (Figs 102, 106). Eye rudiments present, composed of one to five ommatidia without pigmentation. Punctation of pronotum fine, but at least in posterior portion distinct, more distinct than that of elytra. Ventral process of aedeagus short, broad, and apically convex in ventral view; internal sac without sclerotized ring-shaped dorsal structure. Cephennium arcuatum group.

- Antennomere XI short and conical, only weakly oblong (Fig. 114). Eyes completely absent. Punctation of pronotum extremely fine, indistinct, similar to that of elytra. Ventral process of aedeagus longer, less broad, apically pointed in ventral view; internal sac with sclerotized ring-shaped dorsal structure. Species from Central and East Crete. Cephennium sinuosum group.

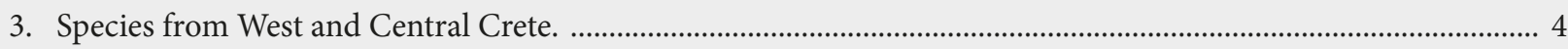

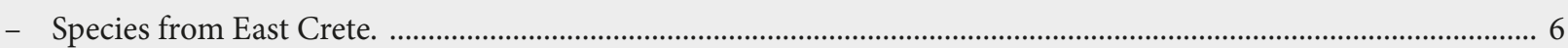

4. Species from Central Crete (Psiloritis). Aedeagus as in Figs 111-113. ...................................................... idanum

- Species from West Crete. Aedeagus different ......................................................................................................... 5

5. Species from Southwest Crete. Aedeagus as in Figs 107-108, internal sac with two pairs of larger spines in internal sac, without additional smaller spines. selinonum

- Species from the region to the southwest of Chania. Aedeagus as in Figs 109-110, internal sac with two pairs of larger spines and with numerous additional smaller spines. meybohmi

6. Distribution: Orno Thriptis in the extreme east of Crete. Aedeagus as in Figs 104-105. thripticum

- Distribution: Dikti range. Aedeagus as in Figs 102-103 arcuatum

7. Species from Central Crete (Psiloritis). Antenna $0.45 \mathrm{~mm}$ long. Aedeagus with ventral process broad (ventral view), somewhat resembling a house in cross-section, and with internal structures of distinctive shapes (Figs 125-126).

latius

- Species from East Crete. Antenna shorter. Aedeagus with ventral process either stout and not house-shaped or more slender in ventral view, and with internal structures of different shapes.

8. Aedeagus with very broad (ventral view) and stout (lateral view) ventral process and with internal structures of distinctive shapes (Figs 118-119). Known only from Zakros in the extreme east of Crete. fortespinosum

- Aedeagus with more slender and less stout ventral process; internal structures different. 9

9. Slightly larger species: body length $0.92-0.99 \mathrm{~mm}$; width of pronotum $0.37-0.39 \mathrm{~mm}$; width of elytra $0.39-0.40 \mathrm{~mm}$. Internal structures of aedeagus distinctly curved (Figs 115-117). East Crete: environs of Sitia. sinuosum

- Slightly to distinctly smaller spccies. Internal structures of different shape.

10. Smaller species: body length $\leq 0.90 \mathrm{~mm}$. Aedeagus with three pairs of long and nearly straight internal spines, the lateral spines with a small hook (Figs 120-121). East slope of Dikti range (environs of Kritsa). hamulatum

- Slightly larger species: body length > $0.90 \mathrm{~mm}$. Aedeagus with internal structures of different shapes. 11

11. Ventral process of aedeagus with longer and more pointed apex; internal sac with shorter spines, two of them strongly curved in ventral view (Fig. 122). North slope of Orno Oros in the extreme east of Crete. curvatum

- Ventral process of aedeagus less strongly pointed apically; internal sac with six long and only apically slightly curved spines (Figs 123-124). Selena Oros to the southeast of Malia. selenanum 
valley, $35^{\circ} 24^{\prime} 10^{\prime \prime} \mathrm{N}, \quad 23^{\circ} 53^{\prime} 53^{\prime \prime} \mathrm{E}, 290 \mathrm{~m}, \quad$ 18.III.2018, V. Assing” (cAss); 1 ㅇ: "N3521'31 E2349'29, GR Westkreta (30) Prases, $10 \mathrm{~km}$ w Omalos $760 \mathrm{~m}$, Brachat

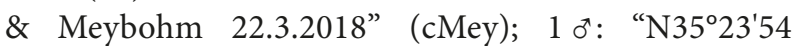
E235'ㄱㅇ, GR Westkreta 440 m, Karanos W 21.3.2019, Brachat \& Meybohm (14)” (cMey).

Etymology: The specific epithet is an adjective derived from Chania, the name of the prefecture (comprising West Crete) where this species was collected.

Description:Bodylength 1.05-1.15 mm; width of pronotum $0.38-0.40 \mathrm{~mm}$; width of elytra $0.44 \mathrm{~mm}$. Habitus as in Fig. 127. Coloration: body pale-reddish; legs and antennae yellow; maxillary palpi pale-yellow. Eyes completely absent. Head, pronotum, and elytra without microsculpture. Pubescence sparse, long, suberect, and whitish, directed predominantly posteriad on head and elytra, diagonally postero-mediad on most of pronotum, and transversely mediad at posterior margin of pronotum. Punctation of head extremely fine, barely noticeable at a magnification of $150 \mathrm{x}$, that of pronotum very fine, but visible, and that of elytra fine, slightly more distinct than that of pronotum. Tibiae without evident sexual dimorphism, club-shaped, dilated in distal two-thirds, pro- and mesotibiae more so than metatibiae; meso- and metatibae flattened on internal side (i.e., side facing the body). Antenna $0.5 \mathrm{~mm}$ long, with distinct club formed by the large antennomeres IX-XI; antennomere VIII much smaller than antennomere IX, but only slightly smaller than antennomere VII; antennomere XI approximately 1.5 times as long as broad. Pronotum transverse, approximately 1.15 times as broad as long, rather strongly dilated in anterior half. Elytra with somewhat obtuse antero-lateral process and with a distinct humeral fold.

$\sigma^{\star}$ : aedeagus $0.33-0.35 \mathrm{~mm}$ long; ventral process strongly bisinuate and apically acute in lateral view; internal sac with massive and strongly sclerotized spines (Figs 128-129).

Comparative notes: Cephennium chanianum is distinguished from other Cretan species not only by the shape and internal structures of the aedeagus, but also by larger body size and a differently shaped pronotum (anteriorly more strongly dilated).

Distribution and natural history: The known distribution of C. chanianum ranges from the region to the southwest of Kissamos to the region to the southwest of Chania in West Crete. The altitudes range from 290 to $760 \mathrm{~m}$. Four specimens were found in stream valleys with old Platanus orientalis, one in a pasture with old chestnut trees. With one exception, all the specimens were collected by soil-washing.

\section{On Scydmoraphes ziegleri Meүвонм, 2008}

The original description is based on a single male collected from under a deeply embedded stone. In the meantime, 16 additional specimens, five males and eleven females, have been found, all of them using the soil-washing technique. All the females have strongly reduced eyes composed of approximately four ommatidia. The three males from the region to the west of Agios Nikolaos have large and strongly projecting eyes, as well as fully developed hind wings, whereas the three males from Zakros in the extreme east of Crete are wingless and have strongly reduced eyes (like the females). In addition, the nine specimens from the eastern tip of Crete are distinguished from the six specimens from the environs of Agios Nikolaos by more transverse antennomeres VIII, IX, and X, as well as by more strongly reduced eyes in the females. However, the two females from Lastros are intermediate in this respect and differences in the male genitalia were not found, so that all the material is attributed to $S$. ziegleri.

\section{Euconnus (Tetramelus) zakrius Meyвoнm spec. nov. urn:Isid:zoobank.org:act:506C3D6D-FD24-4484-813D-F00E761EFECB (Fig. 130)}

Type material: Holotype $0^{\star}$ : “GR Ostkreta Ano Zakros l. Meybohm 20.3.1986 / Euconnus (Tetramelus) zakrius m. Meybohm 2018 det. / Holotypus" (cMey). Paratypes (all in cMey): $15 \sigma^{\star} \sigma^{\star}, 14$ 우: same data as holotype; 3 o $^{\star}$, 2 우 우 : "Ost-Kreta Zakros 21.3.[19]76 DrFülscher Meybohm”; 1 ๙ , 1 ㅇ: "GR-Kreta Bez. Lassithi Zakros 29.5.1980 leg. Brachat"; $8 \sigma^{\star} \sigma^{\star}$ : "GR - Crete [16], Zakros, 350 $66^{\prime} 57^{\prime N}$, 26 $16^{\circ} 10^{\prime \prime E}, 190 \mathrm{~m}$, dry stream valley, soil washing, 27.XII.2018, V. Assing"; 10 o $^{\text {त }}$, 4 우 오 : N35 $06^{\prime} 57$ E26ํ1'10, GR Ostkreta Ano Zakros, 14.3.2019, Brachat \& Meybohm (1)”.

Etymology: The specific epithet is an adjective derived from Zakros.

Description: Body size subject to weakly pronounced sexual dimorphism; body length $1.47-1.57 \mathrm{~mm}\left(\sigma^{*}\right)$ and $1.50-1.60 \mathrm{~mm}$ ( क ), respectively. Coloration uniformly pale reddish-brown. Pubescence rather sparse, directed posteriad, sub-erect, and bent apically. Punctation of head, pronotum and elytra very fine.

Head approximately $0.25 \mathrm{~mm}$ broad, broadest across the minute eyes, weakly oblong, slightly more than 1.1 times as long as broad, lateral contours smoothly curved from the eyes to the posterior constriction, postero-medially bulging and distinctly projecting beyond posterior constriction. Eyes rudimentary, composed of approximately four ommatidia, without pigmentation. Antenna $0.7 \mathrm{~mm}$ long, with distinct four-jointed club; antennomeres II twice as long as broad, III-V cylindrical and about 1.7 times as long as broad, VI little longer than 
broad, VII intermediate between VI and VIII, as long as broad, VIII-XI about twice as broad as VII, VIII to XI gradually increasing in width, and XI slightly shorter than the combined length of IX and X.

Pronotum 1.2 times as broad as head and 1.2 times as long as broad, broadest slightly anterior to middle, more strongly tapering anteriad than posteriad; basally with four foveae of different size, the external ones smaller, separated from each other by approximately the diameter of the internal foveae; basal keel absent.

Elytra on average $0.60 \mathrm{~mm}$ broad and slightly less than 1.5 times as long as broad ( 9 ), or on average $0.625 \mathrm{~mm}$ broad and slightly more than 1.5 times as long as broad $\left(o^{\star}\right)$; each elytron with two clearly separated basal foveae, the external one larger and laterally delimited by a short elevation, the internal one delimited by an oblique edge directed towards suture. Hind wings completely reduced. Femora dilated in distal halves; profemora more strongly dilated than meso- and metafemora. Protibia smoothly curved distally, in male slightly more so than in female. Metaventrite in male with a large and shallow median impression, this impression not delimited by elevations, in female weakly convex (cross-section).

$\mathrm{o}^{\mathrm{T}}$ : mesotrochanter unmodified; aedeagus $0.39-0.41 \mathrm{~mm}$ long, shaped as in Fig. 130.

Comparative notes: Euconnus zakrius is characterised particularly by the morphology of the aedeagus, which in some respects (nearly symmetrical, dorsal plate with wing-like lateral dilatation and projecting from the lateral contours of the aedeagus, two large sclerites projecting from basal capsule) resembles those of E. kerpensis Мечвонм, 2016 from Karpathos, E. kerkisicus Меувонм, 2017, E. ambelosicus Меувонм, 2017, and E. samius Мечвонм, 2017 from Samos, and one undescribed species from Rhodos, suggesting that these six species are closely related (Меувонм 2017).

Distribution and natural history: This species is endemic to the easternmost part of Crete and was only found in Ano Zakros. The specimens were partly sifted from debris and litter, partly collected by soil-washing in a small temporary stream valley at an altitude of $220 \mathrm{~m}$.

\section{Stenichnus (Stenichnus) brachati MeYBOHM spec. nov urn:Isid:zoobank.org:act:0D694A13-AB82-4398-AC2A-2E4D39B515FB (Figs 131-133)}

Type material: Holotype ơ: "26.3.[19]76 Kreta Anogia Ida-Geb. Dr Fülscher Meybohm / Stenichnus brachati m. Meybohm 2018 det. / Holotypus" (cMey). Paratypes (all in cMey): Lassithi: $10^{\circ}, 1$ \% : “N35 $05^{\circ} \mathrm{E} 25^{\circ} 52^{\prime}$ GR Ostkreta Thripti $900 \mathrm{~m}$ Meybohm 8.3.2001"; 1 \% : "N3505'09 E2552'10 GR Ostkreta (3) Thripti 1040 m 10.3.2018 1. Brachat \& Meybohm"; $10^{*}:$ "GR - Crete [9],

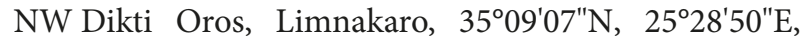
$1090 \mathrm{~m}$, under stones, 26.III.2012, V. Assing"; $1 \mathrm{o}^{\star}$ : same data, but "27.III.2012"; 1 o , 2 ㅇ 9 : same data, but "sifted, 27.III.2012"; $4 \sigma^{\star} \sigma^{\star}, 1$ ㅇ: same data, but "sifted, 30.III.2012"; 3 o $^{\star} 0^{\star}, 5$ 우 우: "GR - Crete [12a], NW Dikti Oros, Limnakaro, 350' $16^{\prime \prime} \mathrm{N}, 25^{\circ} 28^{\prime} 52^{\prime \prime E}, 1140 \mathrm{~m}$, under stones, 28.III.2012, V. Assing"; $2 o^{*} 0^{7}:$ "GR - Crete [9], NW Dikti Oros, $1440 \mathrm{~m}, \quad 35^{\circ} 07^{\prime} 26^{\prime \prime N}, \quad 25^{\circ} 29^{\prime} 23^{\prime \prime E}$ snowfield margin sifted, 9.IV.2014, V. Assing"; 5 우: “N3505' E2532' GR Kreta Dikti-Geb. Selakano $850 \mathrm{~m}$ Meybohm 9.3.2001"; 1 \%: "N35¹1' E2531' GR Kreta Lassithi Selia Afhin $1000 \mathrm{~m}$ Meybohm 10.3.2001"; 2 우 우: "GR - Crete [11], W Kritsa, 3509'41"N, 2538'21"E, $450 \mathrm{~m}$, soil washing, 27.XII.2017, V. Assing”; 2 우 : “N3507'02 E2537'55 GR Lassithi (8) Kroustas sw 800 m 12.3.2018 1. Brachat \& Meybohm"; 1 \%: “GR - Crete

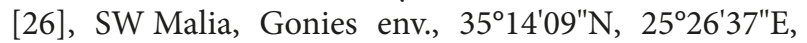
$290 \mathrm{~m}$, soil washing, 1.I.2018, V. Assing”; 1 : "N35¹4'09

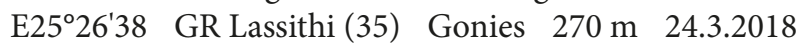
1. Brachat \& Meybohm"; $10^{*}$ : “GR - Crete [20], WSW Ag. Nikolaos, Katharo, $35^{\circ} 08^{\prime} 14^{\prime \prime} \mathrm{N}, 25^{\circ} 34^{\prime} 25^{\prime \prime E}, 1140 \mathrm{~m}$,

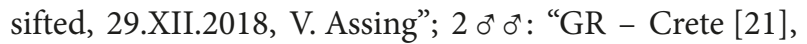

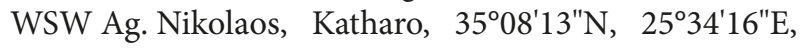
$1110 \mathrm{~m}$, under stones, 29.XII.2018, V. Assing"; $2 o^{\star} o^{\star}, 1$; : "GR - Crete [29], S Kritsa, SW Kroustas, 3507'03"N, 253' $10^{\prime \prime E}, 780 \mathrm{~m}$, litter sifted, 31.XII.2018, V. Assing"; $2 \sigma^{\top} \sigma^{\top}$ : “N35¹0'40 E2603'00, GR Ostkreta 15.3.2019, Kimouriotis 110 m, Brachat \& Meybohm (3)"; 2 우 운 “N3507'02 E2537'55, GR Kreta Lassithi 800 m, Kroustas sw 16.3.2019, Brachat \& Meybohm (5)". Rethimno: 2 우 우: “30.3.[19]73 Kreta Ida-Geb. b. Anogia DrFülscher Meybohm”; 2 우: ‘'14.3. [19]76 Kreta Anogia Ida Geb. DrFülscher Meybohm"; $8 o^{\star} o^{\star}, 7$ ㅇ ㅇ: “26.3.[19]76 Kreta Anogia Ida Geb. DrFülscher Meybohm"; $20^{\star} o^{\star}$, 7 우 우: “27.3.1986 Kreta Ida Geb. Umg. Anogia leg. H. Meybohm"; 1 o", 3 우: "GR-Kreta Bez. Rethimnon Anogia/Ideon Antron 25.-27.5.1980 leg. Brachat"; $3 \sigma^{\star} \sigma^{\star}$ : "GR - Crete [28a], S Anogia, Psiloritis, 35¹4'59"N, $24^{\circ} 53^{\prime} 05^{\prime \prime E} 1180 \mathrm{~m}$, sifted, 3.IV.2012, V. Assing”; $20^{\top} \mathrm{o}^{\top}$,

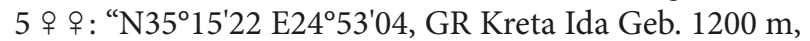
Anogia-Psiloritis 17.3.2019, Brachat \& Meybohm (7)”. Chania: 1 \%: "23.3.[19]73 West-Kreta Paß PetresImpros DrFülscher Meybohm"; 1 ơ⿱ $^{\text {: }}$ "GR-Kreta Bez. Chania Chora Sfakion-Impros 31.3.1983 leg Brachat/ Dörnfeld"; $1 \sigma^{\top}$ : "16.3.19[76] West-Kreta OmalosHochfläche DrFülscher Meybohm”; $1 o^{\star}$ : “24.3.[19]86 WestKreta Omalos Hochfläche leg. H. Meybohm”; 1 i : "N3519'E235' GR Westkreta Omalos 1150-1480 m Meybohm 13.3.2001"; 1 ơ, 1 \%: “GR W-Kreta Umgeb. Omalos ca. 1100 m Streuges. 10.[19]91 Wunderle"; 1 q: "N3519'10 E235'ㄴ 46 GR Westkreta (16) Omalos 1110 m 16.3.2018 1. Brachat \& Meybohm"; 1 i : same data, but 18.3.2018; $10^{*}$ : "GR Westkreta (16) N35 ${ }^{\circ} 19^{\prime} 10$ E235' 46 Omalos 1110 m; 16.3.2018 leg. Meybohm \& Brachat";

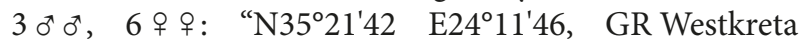
130 m, Vrisses S 19.3.2019, Brachat \& Meybohm (10)";

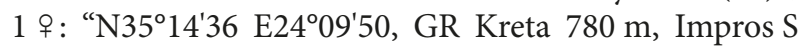
22.3.2019, Brachat \& Meybohm (16)"; 1 우 “N35ำ19'18 E23 54'50, GR Kreta 1060 m, Omalos E 23.3.2019, Brachat \& Meybohm (18)". 
Etymology: This species is dedicated to my friend Volker Brachat, specialist of Pselaphinae, a regular companion on at least one field trip per year since 2000 .

Description: Body length $1.40-1.50 \mathrm{~mm}$. Body bright reddish-brown. Head broadest across the large and moderately projecting eyes; width of head including eyes $0.26-0.30 \mathrm{~mm}$; postocular region in dorsal view distinctly tapering behind eyes, slightly shorter than diameter of eyes; supra-antennal tubercles very weakly pronounced; punctures on vertex and frons distinct; vertex and frons confluent and distinctly convex; pubescence sexually dimorphic: setae on vertex and frons about $0.02 \mathrm{~mm}$ long, weakly curved, directed forward $\left(\sigma^{*}\right)$ or about $0.04 \mathrm{~mm}$ long, distinctly curved, and directed mediad ( ) ). Antenna slender, 0.76-0.89 mm long, antennomeres II broader than III, III-X increasing in width, II-V of subequal length, twice as long as broad, VI 1.5 times as long as broad, VII weakly oblong, VIII as long as broad, three-segmented club weakly separated, IX-X weakly transverse, XI slightly shorter than the combined length of IX and $\mathrm{X}$.

Pronotum of sub-trapezoid shape in dorsal view, 0.37$0.42 \mathrm{~mm}$ long and $0.34-0.37 \mathrm{~mm}$ broad, on average 1.07 times as long as broad, broadest at anterior third; lateral margins strongly rounded in anterior third and straight in posterior half; posterior angles broadly rounded; punctures very fine; pubescence long and suberect, setae approximately $0.1 \mathrm{~mm}$ long, as long as setae on elytra, directed posteriad except at anterior and posterior margins. Pronotum without transverse impression in front of posterior margin, basally with two small foveae separated from each other by the same distance as from posterior margin, laterally with one or few foveae of variable size.

Elytra broadly oval, dorsally weakly flattened, 0.88$0.97 \mathrm{~mm}$ long and $0.61-0.65 \mathrm{~mm}$ broad, on average 1.46 times as long as broad, broadest slightly behind anterior third; humeral angle and humeral fold absent; at base of each elytron with a large deep inner and a small outer impression separated by a weak, longitudinal ridge; pubescence long and suberect, directed posteriad; punctation distinct and moderately fine; elytral apices truncate. Legs relatively long and slender, with dilated femora, profemora with sexual dimorphism and more dilated than mesofemora, the latter more dilated than metafemora.

$\sigma^{\star}$ : profemur distally broadly dilated, with a more or less distinct edge externally, forming an angle of approximately $135^{\circ}$; sternite III with broad and laterally slightly concave median process anteriorly, this process posteriorly with broad and shallow impression nearly reaching posterior margin of sternite, margins of this impression elevated, sternites IV and V medially with a shallow impression, that of sternite IV slightly more extensive than that of sternite $\mathrm{V}$ and with a small cluster of setae anteriorly (Fig. 131); aedeagus as in Fig. 132; sclerotized dorsal portion rather long and broad.
क: sternites IV and V unmodified; spermatheca as in Fig. 133.

Intraspecific variation: The above description strictly applies only to material from Psiloritis. Specimens from Oros Thripti and Oros Dikti are distinguished from those from Psiloritis by shorter antennae with more distinctly transverse antennomeres IX and X and by sometimes blackish-brown elytra. In specimens from West Crete (Lefka Ori), the pubescence of the male vertex is longer, sparse, and directed anteriad and that of the female vertex is very long, very sparse, and directed mediad. Since these differences are not pronounced, they are interpreted as intraspecific variation.

Comparative notes: Stenichnus brachati is similar to S. chius Меувонм, 2016 (Chios), S. lesbius Меувонм, 2016 (Lesbos), and an undescribed species from Samos, but easily distinguished by broader elytra, a unicoloured reddish-brown body, and the sexual characters. In the compared species, the male sternite IV has a sickleshaped impression (S. lesbius) or a minute tomentose patch (S. chius). In the undescribed species from Samos, the male sternite $\mathrm{V}$ is extensively impressed.

Distribution and natural history: This species is endemic to the mountainous regions of Crete from the Lefka Ori in the west to Oros Thripti in the east. The altitudes range from 780 to $1830 \mathrm{~m}$, with two records from lower elevations (130 and $450 \mathrm{~m}$ ).

\section{Stenichnus (Stenichnus) orientalis MeYBOHm spec. nov. urn:Isid:zoobank. org:act:06558FCA-3A62-4019-BFB7-EF06448C1956 (Figs 134-136)}

Holotype ơ: "N3506'57 E26²13'10, GR Ostkreta, Ano Zakros 14.3.2019, Brachat \& Meybohm (1)/Stenichnus orientalis m. Meybohm 2019 det. / Holotypus" (cMey). Paratypes: 2 ㅇ ㅇ: same data as holotype (cMey); $10^{\star}$ : “N350'드 E2538'30, GR Kreta Lassithi 390 m, Kritsa s 16.3.2019, Brachat \& Meybohm (4)" (cMey).

Etymology: The specific epithet (Latin, adjective: eastern) indicates that the species is endemic to the eastern part of Crete.

Description: Habitus as in Fig. 134. External characters as in S. brachati, except as follows:

Body length $1.58 \mathrm{~mm}\left(\sigma^{*}\right)$ and $1.63 \mathrm{~mm}$ ( 9 ). Width of head including eyes $0.29 \mathrm{~mm}$. Pubescence on vertex and frons not sexually dimorphic, in both sexes about $0.06 \mathrm{~mm}$ long, distinctly curved, and directed mediad. Antenna slender, sexually dimorphic: $0.94 \mathrm{~mm}\left(\mathrm{o}^{*}\right)$ and $0.89 \mathrm{~mm}$ ( + ) long, antennomeres IX and X in female distinctly broader than in male. Pronotum $0.36 \mathrm{~mm}$ broad and $0.39 \mathrm{~mm}\left(\sigma^{*}\right)$ and $0.42 \mathrm{~mm}$ ( + ) long, at base laterally with two foveae of similar size as the two median pits. 
Elytra oblong, $1.00-1.05 \mathrm{~mm}$ long and $0.63-0.67 \mathrm{~mm}$ broad, on average 1.57 times as long as broad, strongly convex in cross-section and dorsally not flattened; pubescence very long and erect, setae as long as the combined length of antennomeres III and IV, or nearly so.

$\sigma^{*}$ : profemur distally broadly dilated, externally broadly rounded, not angular; median process of sternite III more slender and laterally more distinctly concave than in S. brachati, apically with fovea, sternite III without shallow impression, shallow impressions on sternites IV and V more distinctly transverse than in S. brachati, with few minute setae anteriorly (Fig. 135); aedeagus as in Fig. 136, dorsal sclerotized portion rather short and narrow.

Intraspecific variation: The male paratype from Kritsa differs from the holotype by distally more dilated profemora, less erect, shorter, but more strongly curved setae on the elytra, and a more distinct fovea on the median process of the male sternite III. However, since the aedeagi are identical, these differences are interpreted as intraspecific variation.

Comparative notes: The similar modifications of the male abdominal sternites III-V suggest that the species is closely related to Stenichnus brachati, S. chius Мечвонм, 2016, and S. lesbius Мечвонм, 2016.

Distribution and natural history: This species is most likely endemic to East Crete, where it was found at low elevations up to $390 \mathrm{~m}$.

\section{Stenichnus (Stenichnus) aegialioides MeYвOHM spec. nov. \\ urn:Isid:Zoobank.org:act:712D1FB1-7AB4-4C27-8CB2-05E07E8435FE (Figs 137-138, 146)}

Type material: Holotype o*: "GR Kreta Bez. Lassithi Zakros 29.5.1980 leg Brachat / Stenichnus aegialioides m. Meybohm 2018 det. / Holotypus" (cMey). Paratypes (all in cMey): Lassithi: $1 \sigma^{x}, 6$ 우 : same data as holotype; 1 đ", 1 \%: “28.3.[19]73 Ost-Kreta Zakros Tal d. Toten DrFülscher Meybohm”; 1 \%: “26.3.[19]73 Kreta Lassithi-Hochebene DrFülscher Meybohm”; $10^{\star}$ : "GR Kreta Lassithi (8) N3507'02 E2537'55 Kroustas sw 800 m 12.3.2018 leg Meybohm \& Brachat"; 1 ㅇ: "GR Crete [25], NE Lassithi Plateau, $35^{\circ} 12^{\prime} 45^{\prime \prime} \mathrm{N}, 25^{\circ} 31^{\prime} 53^{\prime} \mathrm{E}$, 850 m, soil washing, 30.XII.2018, V. Assing”. Rethimno: $10^{\top}$ : “N3517' E24²8' GR Kreta Rethimnon Armeni

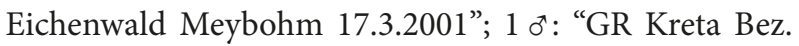
Rethimnon Dariviana b. Spili 3.4.1983 leg. Brachat”; 1 i: "GR - Crete [12], ESE Rethimno, S Roupes, 3519'26"N, $24^{\circ} 38^{\prime} 53^{\prime \prime E}, 400 \mathrm{~m}$, soil washing, 26.XII.2018, V. Assing”; $10^{*}$ : “GR - Crete [15], Psiloritis, NE Livadia, $35^{\circ} 18^{\prime} 56 " \mathrm{~N}$, $24^{\circ} 49^{\prime} 07^{\prime \prime E}, 440 \mathrm{~m}$, soil washing near stream, 26.XII.2018,

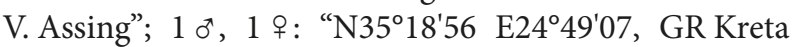
440 m, Livadia NE 16.3.2019, Brachat \& Meybohm (8)”. Chania: 1 ㅇ: "25.3.[19]86 WestKreta Umg. Elos leg.
H. Meybohm"; 1 ㅇ: "GR Westkreta Vrysses $100 \mathrm{~m}$ Meybohm 21.4.2000"; 1 i: “N3521' E2349' GR Westkreta Prases $800 \mathrm{~m}$ Meybohm 13.3.2001”; 2 우 우: "GR - Crete [15a], S Kissamos, NE Sirikari, 35²4'48"N, 2339'04"E, 500 m, dead chestnut, 19.III.2018, V. Assing"; 1 우 “N35²1'21 E2338'21 GR Westkreta (28) Elos $610 \mathrm{~m}$ 21.3.2018 1. Brachat \& Meybohm"; 1 ㅇ: "GR - Westkreta (28) N3521'21 E2338'21 Elos; $610 \mathrm{~m}$; 21.3.2018 leg Meybohm \& Brachat"; $10^{\star}:$ "N3521'31 E2349'29 GR Westkreta (30) Prases $10 \mathrm{~km} \mathrm{w}$ Omalos

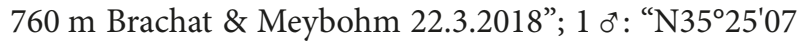
E235'ㄷㄴ GR Westkreta (32) Nteres $210 \mathrm{~m} \mathrm{l}$. Brachat \& Meybohm 23.3.2018”; 2 o $^{\star} 0^{\star}, 1$ 우: “N3521'56 E2337'16, GR Westkreta Louchui, $550 \mathrm{~m}$ 20.3.2019, Brachat

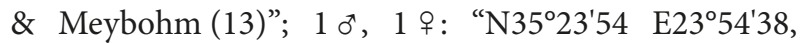
GR Westkreta 440 m, Karanos W 21.3.2019, Brachat \& Meybohm (14)"; 1 ㅇ: "N35ํ19'22 E2353'33, GR Kreta 1050 m, Omalos S 25.3.2019, Brachat \& Meybohm (21)”.

Etymology: The specific epithet alludes to the similarity of this species to Stenichnus aegialius (ReItTER, 1884).

Description: Body length 1.45-1.55 mm. Body unicoloured bright reddish-brown. Head broadest across the large and moderately projecting eyes; width of head including eyes $0.33-0.35 \mathrm{~mm}$; postocular region in dorsal view distinctly tapering behind eyes, half as long as diameter of the eyes; supra-antennal tubercles weakly pronounced; punctures on vertex and frons very fine; vertex and frons confluent and weakly convex, with long and curved suberect setae, these setae as long as antennomere II and directed mediad. Antennae 0.69-0.75 mm long, antennomeres from II to $\mathrm{X}$ of increasing width, II-V of subequal length, 1.5 times as long as broad, VI weakly oblong, VII as long as broad, VIII-X transverse, X 1.5 times as broad as long, XI slightly shorter than the combined length of IX and X.

Pronotum of sub-trapezoid shape in dorsal view, 0.44$0.45 \mathrm{~mm}$ long and $0.40-0.42 \mathrm{~mm}$ broad, broadest at anterior third; lateral margins strongly rounded in anterior third and concave in posterior half; posterior angles broadly rounded; punctures very fine; pubescence long and suberect, setae approximately $0.1 \mathrm{~mm}$ long, as long as setae on elytra, directed posteriad except at anterior and posterior margins; transverse impression near posterior margin extending to lateral margins and dorsally with four and laterally with one or few foveae of variable size.

Elytra broadly oval, dorsally not flattened, ca. $0.95 \mathrm{~mm}$ long and $0.63-0.68 \mathrm{~mm}$ broad, broadest slightly behind anterior third; humeral angles pronounced; base of each elytron with two large impressions, the inner one slightly larger than the outer one. Pubescence long and suberect, directed posteriad, setae inserting from distinct foveae; punctation distinct. Legs with distinctly dilated femora, profemora with sexual dimorphism and more dilated than mesofemora, the latter more dilated than metafemora. 
$\sigma^{\star}$ : profemur (Fig. 146) broadly rounded distally, angled, external side with a fine sulcus reaching from the apex to the middle of the dilatation, thus forming a carina at the outer side of the profemur, carina in the distal part crenulate; aedeagus shaped as in Fig. 137.

ㅇ: spermatheca as in Fig. 138.

Comparative notes: Stenichnus aegialioides is distinguished from the similar S. aegialius by slightly shorter antennae with more transverse antennomeres VIII-X, by the shape of the male profemora, a narrower aedeagus, and a shorter spermatheca. It differs from $S$. godarti (LATREILle, 1806) by smaller body size, longer antennae, more erect elytral pubescence, the shape of the male profemora, an apically shorter and less acute aedeagus, and a longer spermatheca. For comparison, illustrations of the genitalia of $S$. aegialius and S. godarti are provided in Figs 139-142.

Distribution and natural history: This species is endemic to Crete. The altitudes range from 200 to $800 \mathrm{~m}$. the specimens were collected primarily in oak and chestnut forests.

\section{Key to the Stenichnus species of Crete}

1. Body length $<1.3 \mathrm{~mm}$. $\sigma^{*}$ : profemur with angular dilatation; aedeagus as in Fig. 143. creticus

- Body length $>1.4 \mathrm{~mm}$. 2

2. Elytra with pronounced humeral angles. $\sigma^{t}$ : profemur distally with non-angular dilatation; aedeagus as in Fig. 137. aegialioides

- Elytra without humeral angles ... 3

3. Base of pronotum with two small foveae. 4

- Base of pronotum with four large foveae. 5

4. Elytra drop-shaped and depressed, pubescence not conspicuously long. $\sigma^{\star}$ : profemur distally with angular dilatation (angle approximately $135^{\circ}$ ); abdomen as in Fig. 131; aedeagus as in Fig. 132. brachati

- Elytra neither drop-shaped nor depressed, pubescence conspicuously long. $\sigma^{\star}$ : profemur distally with broader, not angular dilatation; abdomen as in Fig. 135; aedeagus as in Fig. 136 orientalis

5. Elytra with very fine, indistinct punctation and with very long erect setae. $\sigma^{\star}$ : profemur with indistinctly angular distal dilatation; aedeagus as in Fig. 145 ...

basimpressus

- Elytra with distinct punctation and long suberect setae. $0^{\star}$ : profemur distally with angular dilatation (angle $90^{\circ}$ ), with a weakly indicated tooth; aedeagus as in Fig. 144.

hummleri

\section{On Stenichnus hummleri, S. basimpressus, and S. creticus}

Stenichnus hummleri is endemic to the westernmost part of Crete. It has been sifted from chestnut and maple litter in localities to the west of the Lefka Ori at altitudes of 200-600 m.

Stenichnus basimpressus is endemic to West Crete eastwards to Psiloritis. Recently collected material was found at altitudes of 300-1400 m. Specimens from Lefka Ori differ from other populations by longer antennae.

The known distribution of S. creticus includes most of Crete and South Turkey. In Crete it was found especially by turning stones, but also by sifting, at a wide range of altitudes from near sea-level to $1200 \mathrm{~m}$.

\section{Leptomastax cretica MeYвOHM spec. nov. urn:Isid:zoobank.org:act:444B05D8-E8CB-4F7F-A9A5-1695EB36C08A (Figs 147-149)}

Type material: Holotype $0^{*}$ : "N35¹9' E235' GR Westkreta Omalos 1150-1480 m Meybohm 13.3.2001 / Leptomastax cretica m. Meybohm 2018 det./ Holotypus" (cMey). Paratypes: Lassithi: $10^{\star}:$ "GR - Crete [12a], NW Dikti Oros, Limnakaro, 350' $16^{\prime \prime} \mathrm{N}, 25^{\circ} 28^{\prime} 52^{\prime \prime} \mathrm{E}$ 1140 m, understones, 28.III.2012, V.Assing”; 1 ㅇ: “N3505' E02532' GR Kreta Dikti-Geb. Selakano $850 \mathrm{~m}$ Meybohm 18.4.2000"; 3 o $^{\star}$, 3 우 우: same data, but 9.3.2001; $1 o^{\star}$,

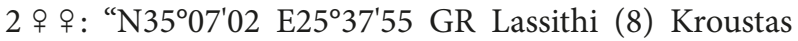
sw 800 m 12.3.2018 1. Brachat \& Meybohm”. Rethimnon: 16 exs.: "30.3.1973 Kreta Ida-Geb. b. Anogia Fülscher \& Meybohm”; 13 exs.: "26.3.1976 Kreta Anogia Ida-Geb. Fülscher \& Meybohm”; 3 exs.: "26.3.[19]86 Kreta Ida Gbg. Nida-Ebene leg. H. Meybohm”; 7 exs.: "27.3.[19]86 Kreta Ida Gbg. Umg. Anogia leg. H. Meybohm”; 1 o , 1 ㅇ: "Kreta/Bez. Rethymnon Umg. Anogia, 25.5.1980 leg. Brachat"; $2 o^{\top} \sigma^{*}, 1$ ㅇ, 1 ex.: "GR-Kreta Bez. Rethimnon Anogia/Ideon Antron 25.-27.5.1980 leg. Brachat (,Leptomastax bisetosa Reitt. C. Castellini det. 1993')"; 4 exs.: Ida Mts., Nida-plateau ca. $0.5 \mathrm{~km} \mathrm{~N}$ Analipsis, $1420 \mathrm{~m}$, $35^{\circ} 12^{\prime} 56 \mathrm{~N} 24^{\circ} 49^{\prime} 52 \mathrm{E}, 21.10 .2006$ M. Schülke (MNB); 2 exs.: "GR Kreta Psiloritis, Niddha 1550 m, Streu N-Hang 10.10. [19]91 Wunderle"; 4 exs.: "GR - Crete [26], Psiloritis Nida Plateau, 1520 m, SW Anogia, sifted 35¹2'10"N,

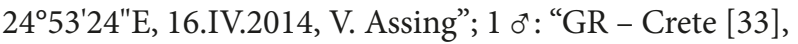
S Anogia, Psiloritis, 35¹5'59"N, 24 53'57"E 1090 m, under stones, 5.IV.2012, V. Assing”. Chania: 8 exs.: “20.3.[19]73 West-Kreta Samaria-Tal, DrFülscher Meybohm”; 5 exs.:

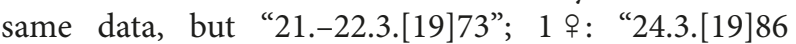
Westkreta Samaria-Schlucht leg. H. Meybohm"; 2 exs.: "17.3.[19]76 West-Kreta Omalos-Hochebene DrFülscher Meybohm”; $10^{\top}$ : "GR-Kreta Bez.Chania Omalos Hochfläche 21.-22.5.1980 leg Brachat ('Leptomastax bisetosa Reitt. C. Castellini det. 1993')"; 20 exs.: "24.3.1986 WestKreta Omalos-Hochfläche leg. H. Meybohm”; $40^{\star} o^{\star}$, 9 우 우: “N3519' E235' GR Westkreta Omalos 1150$1480 \mathrm{~m}$ Meybohm 13.3.2001”; $10^{\top}$ : “N3518' E0235' 
GR Westkreta Omalos Gingilos $1500 \mathrm{~m}$ Meybohm 20.4.2000”; 2 우 우: “N35ำ19' 2351' GR Westkreta Omalos-West $1100 \mathrm{~m}$ Meybohm 14.3.2001"; 1 ㅇ: "GR Westkreta (16) N35 $19^{\prime} 10$ E23 $54^{\prime} 46$ Omalos $1110 \mathrm{~m}$ 16.3.2018 1. Brachat \& Meybohm"; $2 \sigma^{\star} \sigma^{*}:$ same data, but “(16a)18.3.2018”; 1 o : “N35²19'10 E2354'46 GR Westkreta (16) Omalos $1110 \mathrm{~m}$; 16.3.2018 leg. Meybohm \& Brachat"; 1 i : “N3519'23 E2351'59 GR Westkreta (17) Omalos $1100 \mathrm{~m}$ 17.3.2018 1. Brachat \& Meybohm"; 1 ex.: "17.3.[19]76 West-Kreta Umg. Kandanos DrFülscher Meybohm"; 2 o $^{*}$ : "GR - Crete [14], 950 m, 19 km SSW Kissamos, $35^{\circ} 18^{\prime} 27^{\prime \prime N}, \quad 23^{\circ} 36^{\prime} 42^{\prime \prime E}$, u. stones, 30.XII.2013, leg. V. Assing”; 1 ㅇ: “N3521'56 E2337'16, GR Westkreta Louchi, $550 \mathrm{~m}$ 20.3.2019, Brachat \& Meybohm (13)”; 1 ㅇ: “N3519'07 E235'ㄴ, GR Kreta 1080 m, Omalos E 23.3.2019, Brachat \& Meybohm (17)";

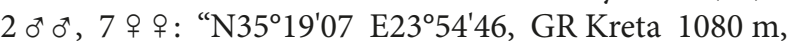
Omalos E 25.3.2019, Brachat \& Meybohm (20)". All paratypes deposited in cMey, except where noted otherwise.

Etymology: The specific epithet indicates that the species is endemic to Crete.

Note: The description fully applies only to material from Psiloritis and Lefka Ori. Specimens from Dikti Oros constantly differ from those from Psiloritis and Lefka Ori by smaller body size, shorter antennae with antennomere III 1.5 times as long as broad, and by apically more broadly rounded elytra.

Description: Body length 1.73-1.83 mm. Body bright reddish-brown. Width of head including the flat eyes $0.39-0.43 \mathrm{~mm}$, length $0.23-0.24 \mathrm{~mm}$; eyes large, with about 14 ommatidia; subocular setiferous punctures and setae absent; postocular region in dorsal view smoothly convexly tapering. Antenna $0.96-1.04 \mathrm{~mm}$ long, antennomeres III about 1.8 times as long as broad, IV-X about as broad as long, VIII weakly transverse. Length of mandibles $0.33 \mathrm{~mm}$ (length measured from the apex to the outer part of the base). Labial palpus (Fig. 147) short, apical palpomere about 3 times as long as broad, setae of penultimate palpomere short.

Pronotum $0.46-0.50 \mathrm{~mm}$ long and $0.39-0.43 \mathrm{~mm}$ broad, basally with two mostly distinct foveolae.

Elytra oval, apically narrowly rounded, dorsally not flattened, $1.05-1.09 \mathrm{~mm}$ long and $0.60-0.63 \mathrm{~mm}$ broad, with internal basal setae; striae I-III decreasing in depth from stria I to stria III and decreasingly distinct towards posterior portion of elytra, striae IV and V weakly indicated by few punctures and confined to anterior portion; metaventrite with weakly pronounced sexual dimorphism, sparsely and finely punctate, and with pubescence directed posteriad.

$\sigma^{*}$ : metaventrite in postero-median portion with shallow impression, this impression in the middle with longitudinal elevation; aedeagus (Figs 148-149) $0.26 \mathrm{~mm}$ long and $0.09 \mathrm{~mm}$ broad.

: metaventrite flat, unmodified.
Comparative notes and comment: The original description of L. bisetosa ReITter, 1884 is based on a unique specimen from Corfu. CAstellini (1996) designated a neotype from Corfu and attributed material from Crete to the same species, describing and illustrating not only similarities, but also pronounced differences particularly in body size, in the morphology of the head, and in the internal structures of the aedeagus, which he interpreted as intraspecific variation. Additional differences not mentioned in this article concern the basal foveolae of the pronotum, as well as the shapes of the labial palpi and of the metaventrite. In L. bisetosa, the labial palpi are long with the apical palpomere conically acute and approximately 8 times as long as broad at base (Fig. 151). The pronotum lacks basal foveolae. The metaventrite is smooth, with few punctures near the metacoxae at most and without pubescence. The male metaventrite is conspicuously modified, with a pronounced impression with a median keel in posterior half, anterior to this impression with a keel-shaped elevation forming an angle at the anterior margin of the posterior impression. The female metaventrite has a smooth (not keel-shaped) median elevation. In view of the pronounced and constant differences between L. bisetosa and the populations from Crete, the latter undoubtedly represent a distinct species.

Aside from L. cretica, basal foveolae of the pronotum are present also in some species from Turkey, whereas they are absent in species with more western distributions.

Distribution and natural history: See section on L. thriptica.

\section{Leptomastax thriptica MeYBohm spec. nov. urn:Isid:zoobank.org:act:5EA83082-7F64-4122-852C-AECB11BF6D01 (Fig. 150)}

Type material: Holotype ơ: "GR Ostkreta Thripti $1000 \mathrm{~m}$ N2552' E253' leg. Meybohm 14.4.2000/ Leptomastax thriptica m. Meybohm 2018 det. / Holotypus" (cMey).

Etymology: The specific epithet is an adjective derived from Thripti Oros, where this species may be endemic.

Description: Body length $1.63 \mathrm{~mm}$. Body bright reddish brown. Head including the flat eyes $0.40 \mathrm{~mm}$ wide and $0.23 \mathrm{~mm}$ long; eyes large with about 14 ommatidia; subocular setiferous punctures and setae absent; postocular region in dorsal view anteriorly weakly and posteriorly more distinctly tapering. Antenna $0.83 \mathrm{~mm}$ long; antennomeres III slightly longer than broad, IV-X broader than long, VIII almost twice as broad as long. Length of mandibles $0.33 \mathrm{~mm}$ (measured from apex to external part of the base). Labial palpi moderately long, apical palpomere about 5 times as long as broad, setae of penultimate palpomere moderately long. 
Pronotum $0.45 \mathrm{~mm}$ long and $0.39 \mathrm{~mm}$ broad, without basal foveae.

Elytra broadly oval, dorsally flattened between striae II, $0.95 \mathrm{~mm}$ long and $0.58 \mathrm{~mm}$ broad, without internal basal setae; striae I-III decreasing in depth from stria I to stria III and decreasingly distinct towards posterior portion of elytra, striae IV and V weakly indicated by few punctures and confined to anterior portion.

$\sigma^{\star}$ : metaventrite laterally sparsely and finely punctate, with pubescence directed posteriad, impunctate along middle, in posterior half with conspicuous impression with median keel, anteriorly with a keel-shaped elevation forming an angle at anterior margin of the posterior impression; aedeagus $0.31 \mathrm{~mm}$ long and $0.10 \mathrm{~mm}$ broad, shaped as in Fig. 150.

Comparative notes: This species is similar to L. bipunctata Reitter, 1881, especially in the structure of the male metaventrite, but distinguished by the internal structures of the aedeagus. It differs from L. cretica by the modifications of the male metaventrite, the absence of basal foveolae on the pronotum, the presence of internal basal setae on the elytra, and by the morphology of the aedeagus.

Distribution and natural history: Aside from the widespread L. bipunctata, the genus Leptomastax PirAzzoli, 1855 is represented in Crete by two named endemic species, with L.cretica distributed in Dikti Oros, Psiloritis, and Lefka Ori, and with L. thriptica confined to Oros Thripti. All the specimens were collected by sifting moist litter at elevations above $550 \mathrm{~m}$. A female of a probably undescribed endemic species was found under a deeply embedded stone in a Quercus ilex forest near Kroustas at an altitude of $800 \mathrm{~m}$.

\section{Pselaphinae}

\section{Afropselaphus doernfeldae BRACHAT spec. nov. urn:Isid:zoobank.org:act:96DFC249-A208-44CE-BC83-4BB829F6966B (Fig. 152)}

Type material: Holotype o*: "GR-Kreta, Bez. Chania, Samaria Schlucht, 28.3.1983, leg Brachat/ Dörnfeld / Afropselaphus doernfeldae spec. nov. ơ, det. Brachat 2.2019 / Holotypus" (cBra). Paratypes: $10^{\star}, 1$ i : same data as holotype (cBra).

Etymology: This species is dedicated to Cornelia Dörnfeld, one of the collectors of the type series.

Description: Body length $1.75 \mathrm{~mm}$. Body reddish-brown, glossy, smooth, with scattered long yellowish setae, these setae arranged in series on discs of elytra.

Head oblong, length $0.37 \mathrm{~mm}$, width $0.26 \mathrm{~mm}$; frons with pair of carinae reaching the distinct and tomentose frontal foveae, these foveae separated from each other by approximately their diameter; between frontal foveae and the posterior margin of the head with a concave impression. Eyes small, composed of only 7-8 ommatidia, but projecting from lateral contours of head, approximately half as long as the straight and posteriorly converging temples. Antenna $0.92 \mathrm{~mm}$ long, with three-jointed club; all antennomeres oblong; antennomere XI large, as long as the combined length of antennomeres VIII-X. Maxillary palpomere IV in apical half shaped like a slender club, narrowly sulcate.

Pronotum $0.31 \mathrm{~mm}$ long and $0.37 \mathrm{~mm}$ broad, as broad as, and slightly shorter than head, broadest in the middle, with two small lateral impressions; lateral margins convex.

Elytra approximately 1.5 times as broad as long (length $0.37 \mathrm{~mm}$; width $0.57 \mathrm{~mm}$ ); humeral angles obsolete; anteriorly with two basal foveae separated by a short keel; posterior margin with dense suberect pubescence. Hind wings completely reduced. Legs unmodified.

Abdomen with large tergite IV (length $0.50 \mathrm{~mm}$; width $0.56 \mathrm{~mm}$ ), basally with dense scaly pubescence and a shallow impression occupying the median three-fifths of tergite.

$\sigma^{*}$ : metaventrite strongly convex; sternite IV in anterior half with a shallow triangular impression medially; aedeagus (Fig. 152) $0.32 \mathrm{~mm}$ long, apico-medially narrower and slightly bent ventrad; parameres apically each with two setae; internal sac without sclerotized structures.

Comparative notes: Afropselaphus doernfeldi and the following species belong to a species group including several undescribed species from South Turkey and A. clavigeroides (REITter, 1882) from Lebanon and Israel. The new species is distinguished from the latter by the internal structures of the aedeagus and the more distinct median impression near the base of the pronotum.

Distribution and natural history: This species is probably endemic to the Lefka Ori (West Crete). The specimens were sifted from litter.

\section{Afropselaphus assingi BRACHAT spec. nov. urn:Isid:zoobank.org:act:A29A770B-1104-4BBO-BA7E-ADA1CB04D204 (Fig. 153)}

Type material: Holotype $o^{*}$ : "GR - Crete [7a] $1590 \mathrm{~m}$, SW Chania, SE Omalos, 35¹9'19"N, 2355'46"E, sifted, 26.XII.2013, V. Assing \& T. Forcke / Afropselaphus assingi spec. nov. $0^{*}$, det. Brachat 2.2019 / Holotypus" (cBra). Paratypes: $10^{\star}, 1$ \%: “N35¹9'07 E2354'46, GR Kreta, $1060 \mathrm{~m}$, Omalos E, 23.3.2019, leg. Meybohm \& Brachat (17)" (cBra).

Etymology: This species is dedicated to Volker Assing, who first discovered it. 
Description: Similar to A.doernfeldae, distinguished as follows: body length $1.65-1.75 \mathrm{~mm}$. Coloration yellowish-brown to reddish-brown. Head $0.36 \mathrm{~mm}$ long and $0.26 \mathrm{~mm}$ broad; frontal foveae closer, separated by a distance less than their diameter; concave impression between frontal foveae and posterior margin of head more deeply impressed along middle. Antenna slightly shorter, $0.89 \mathrm{~mm}$ long. Pronotum $0.29-0.30 \mathrm{~mm}$ long and $0.26-0.28 \mathrm{~mm}$ broad. Elytra $0.37-0.38 \mathrm{~mm}$ long and $0.56-0.58 \mathrm{~mm}$ broad.

$\sigma^{7}$ : metaventrite weakly convex, posteriorly flattened and with fine median sulcus; sternite IV in anterior half with a shallow oval median impression; aedeagus (Fig. 153) slightly longer (length $0.34-0.36 \mathrm{~mm}$ ), apico-medially narrowed and bent ventrad; parameres each with two apical setae; internal sac with a long sclerite, this sclerite bifid and apically bent laterad.

Comparative notes: Afropselaphus assingi is distinguished from other Cretan species of the genus by the shape of the metaventrite and by the internal structures of the aedeagus.

Distribution and natural history: This species is most likely endemic to the Lefka Ori, East Crete. The type specimens were sifted from litter under bushes at 1060 and $1590 \mathrm{~m}$.

\section{Afropselaphus diktianus Brachat spec. nov. urn:Isid:zoobank.org:act:AF308CB8-7539-4626-8E2C-DD2A7E9B5052 (Fig. 154)}

Type material: Holotype ơ: "GR - Crete [12a], NW Dikti Oros, Limnakaro, 350' $16^{\prime \prime} \mathrm{N}, 25^{\circ} 28^{\prime} 52^{\prime \prime E}, 1140$ m, under stones, 28.III.2012, V. Assing / Afropselaphus diktianus spec. nov. ơ, det. Brachat 2.2019 / Holotypus" (cBra). Paratypes: $10^{\star}, 3$ 우 오 : same data as holotype (cBra).

Etymology: The specific epithet is an adjective derived from Dikti Oros, the mountain range where the species is probably endemic.

Description: Similar to A.dornfeldae and A. assingi, distinguished as follows: body length $1.65-1.80 \mathrm{~mm}$. Coloration reddish-brown with yellowish maxillary palpi. Head $0.37-0.40 \mathrm{~mm}$ long and $0.24-0.26 \mathrm{~mm}$ broad; frontal foveae separated by approximately their diameter. Eyes small, composed of 6-8 ommatidia. Pronotum with very small postero-median impression.

$\sigma^{*}$ : metaventrite less convex, with a minute fovea near posterior margin; sternite IV in postero-median portion with nearly obsolete shallow impression; aedeagus (Fig. 154) $0.32-0.34 \mathrm{~mm}$ long, apically convexly tapering and weakly bent ventrad; internal sac with two long, slender, and weakly sclerotized rod-like structures; parameres apically each with three short setae.
Comparative notes: This species is distinguished from the otherwise similar $A$. dornfeldae and $A$. assingi only by the shape of the male metaventrite and by the morphology of the aedeagus.

Distribution and natural history: Afropselaphus diktianus is most likely endemic to the Dikti Oros, East Crete. The specimens were were collected from under stones near snow at an altitude of $1140 \mathrm{~m}$.

\section{Afropselaphus thripticus BRACHAT spec. nov. urn:Isid:zoobank.org:act:E38E8556-0E8F-4C12-BD99-3759694D8E82 (Fig. 155)}

Type material: Holotype ơ: "N3505', E02552, GR Ostkreta, Thripti 1000 m, Meybohm 11.3.2001 / Afropselaphus thripticus spec. nov. $0^{*}$, det. Brachat 2.2019 / Holotypus" (cBra). Paratypes (all in cBra): $1 \sigma^{*}$ : "GR Ostkreta, Thripti 1000 m, Meybohm 14.4.2000"; $1 \sigma^{*}$ : "GR - Crete [5], Orno Thriptis, SE Thripti, $1130 \mathrm{~m}$,

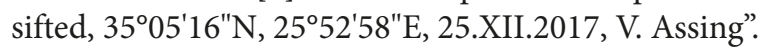

Etymology: The specific epithet is an adjective derived from Orno Thripti, the mountain in East Crete where the species was collected and where it is probably endemic.

Description: Similar to A. dornfeldae, distinguished as follows: body length $1.7-1.8 \mathrm{~mm}$. Coloration reddishbrown with yellowish maxillary palpi. Head $0.38-0.40 \mathrm{~mm}$ long and $0.26-0.28 \mathrm{~mm}$ broad; frontal foveae separated by approximately their diameter. Eyes small, composed of 7-8 ommatidia. Antenna longer, 1.00-1.07 mm long; all antennomeres oblong. Pronotum as long as broad (length and width $0.26-0.28 \mathrm{~mm}$ ) and as broad as head, with small postero-median impression.

$\sigma^{\star}$ : metaventrite convex; sternite IV without median impression; aedeagus (Fig. 155) 0.38-0.42 mm long, slender; internal sac with a long symmetric structure furnished with numerous microsetae; parameres apically each with 4-5 short setae.

Comparative notes: Afropselaphus thripticus is distinguished from all other Cretan representatives of the genus particularly by the distinctive morphology of the aedeagus.

Distribution and natural history: This species is most likely endemic to the Orno Thripti, East Crete. All the specimens were found by sifting litter. The paratype from 2017 was collected by sifting litter, roots, moss, and soil in a rocky slope with Quercus ilex. The altitudes range from 1000 to $1130 \mathrm{~m}$. 


\section{Amauronyx paganettii BLATTnÝ \& BLATTNÝ, 1916}

Type material: Lectotype $\sigma^{\star}$, present designation: "Kreta, Paganetti / A. Paganettii, det. Blattný / Amauronys Paganettii Bltny / Lectotype 1956 det. Kamp. / Typ / paganettiii Blatt., Cl. Besuchet det. VI.1958 / Lectotypus Amauronyx paganettii Blatt. ơ, Cl. Besuchet dét. I.1975 / ex Orig. Samlg. J. Breit Wien / Type / Lectotypus designiert Brachat" (NHMB). Paratypes: 1 [ [without head and pronotum]: same data as lectotype, but "Amauronyx spec. / Paralectotypus" (NHMB).

Comment: The original description is based on an unspecified number of syntypes from "Kreta" without further specification of the locality (BLATTNÝ \& BLATTNÝ, 1916). Two syntypes are deposited in the Frey collection at the NHMB, one of them a male and the other a female in very poor condition. The male had been examined and subsequently labeled as the lectotype by Claude Besuchet in 1958 and 1971, respectively. The designation, however, was never published. In order to fix the present interpretation of this species, this specimen is here designated as the lectotype. The identity of the female paralectotype remains uncertain.

\section{Amauronyx chanianus Brachat spec. nov. urn:Isid:zoobank.org:act:833A774F-4626-4CC8-8BE0-7B857E33EC43 (Fig. 156)}

Type material: Holotype ơ: "GR - Crete [24], SW Chania, SW Prases, $35^{\circ} 21^{\prime} 32^{\prime \prime} \mathrm{N}, 23^{\circ} 49^{\prime} 28^{\prime \prime E}, 740 \mathrm{~m}$, soil washing, 20.III.2018, V. Assing / Amauronyx chanianus spec. nov. $\sigma^{7}$, det. Brachat 2.2019 / Holotypus" (cBra). Paratype + : same data as holotype, but "litter sifted" (cBra).

Etymology: The specific epithet is an adjective derived from Chania, the prefecture where the type locality is situated.

Description: Body $1.8-1.9 \mathrm{~mm}$ long, reddish-brown, glossy, with slightly paler maxillary palpi. Pubescence short and depressed, with scattered longer and suberect setae. Head distinctly transverse, $0.36 \mathrm{~mm}$ long and $0.46 \mathrm{~mm}$ broad; dorsally with two larger intra-ocular foveae, distinctly convex, and with median keel near posterior margin; laterally with sharp carina extending posteriad from the antennal tubercles. Eyes small, composed of 8-9 ommatidia (partly without pigmentation), weakly protruding from lateral contours of head, and much shorter than the convex postocular region. Antenna $0.78-0.80 \mathrm{~mm}$ long, approximately as long as the combined length of head and pronotum, with threejointed club; antennomeres I-III weakly oblong, III apically broadened, IV and V approximately a long as broad, VI slightly smaller and as long as broad, VII as long as broad and of similar size as IV and V, VIII weakly transverse, IX distinctly transverse, X 1.5 times as broad as long, and XI large, of ovoid shape, approximately 1.5 times as long as broad, and as long as the combined length of VIII-X.

Pronotum broadest in anterior third, weakly transverse (length $0.40 \mathrm{~mm}$; width $0.43 \mathrm{~mm}$ ); disc with weakly pronounced median sulcus not reaching anterior margin; ante-basal sulcus deep, laterally forming a pit; between this sulcus and posterior margin of pronotum with five distinct impressions.

Elytra nearly 1.5 times as broad as long, 1.25 times as long as pronotum, basally with two deep basal impressions, with indisinct humeral angles; discal sulcus broad, not reaching middle of elytra. Hind wings completely reduced. Legs unmodified.

Tergite IV $0.3 \mathrm{~mm}$ long, basally with two posteriorly diverging short keels of approximately one-fifth the length of tergite, distance between these keels approximately two-fifths of width of tergite.

$\sigma^{*}$ : tergite VIII with the apex slightly bent upwards; mesotibia with short apical spine; protrochanter unmodified; mesotrochanter with narrow carina medially forming a short and apically obtuse spine; metatrochanter with short and narrow carina; aedeagus shaped as in Fig. 156; right paramere slightly longer than left paramere; both parameres apically with three relatively long setae; internal sac with two broad, flat, and apically acute sclerites and slender apically bent structure.

o : tergite VIII apically obtuse.

Comparative notes: Amauronyx chanianus is distinguished from other Cretan representatives of the genus by a distinctly larger head, by the modifications of the male trochanters, and by the internal structures of the aedeagus.

Distribution and natural history: This species is probably locally endemic to the environs of the Lefka Ori, West Crete. The type specimens were collected near Prases (southwest of Chania) by washing soil and sifting deep litter in a steep stream valley with very old Platanus orientalis at an altitude of $740 \mathrm{~m}$.

\section{Amauronyx occidens BRACHAT spec. nov. urn:Isid:zoobank.org:act:0545A123-B114-4014-A05D-2C5EF565D5D9 (Fig. 157)}

Type material: Holotype $\sigma^{*}$ : "GR - Crete [7], NW Kandanos, Strovles, 3522'03"N, 2340'07"E, 410 m, stream valley, 23.XII.2018, V. Assing / Amauronyx occidens spec. nov. ơ , det. Brachat 2.2019 / Holotypus" (cBra). Paratypes (all in cBra): 1 \%: same data as holotype; $10^{\star}, 2$ 우: “GR - Crete [6], S Kissamos, Elos, $35^{\circ} 21^{\prime} 33^{\prime \prime} \mathrm{N}, 23^{\circ} 38^{\prime} 17^{\prime} \mathrm{E}, 560 \mathrm{~m}$, old chestnut, soil washing, 23.XII.2018, V. Assing". 
Etymology: The specific epithet (Latin, adjective: western) alludes to the fact that this is the westernmost representative of the genus in Crete.

Description: External characters as in A.chanianus, except as follows:

Pubescence suberect. Head $0.34 \mathrm{~mm}$ long and $0.41 \mathrm{~mm}$ broad; antennal tubercles laterally with sharp lamella; frons with two intraocular foveae situated behind level of eyes, medially with convex elevation and with small median impression. Eyes composed of 4-7 ommatidia, situated behind middle of head. Antenna compact, $0.70 \mathrm{~mm}$ long; antennomeres I, II, and IX oblong, IV-VIII weakly transverse, and XI in the middle with transverse notch furnished with a series of depressed setae. Pronotum $0.38-0.39 \mathrm{~mm}$ long and $0.41-0.42 \mathrm{~mm}$ broad, of cordiform shape, with a pronounced median sulcus nearly reaching pronotal anterior margin. Elytra 1.25 times as long and 1.4 times as broad as pronotum, with deep discal sulcus.

$\sigma^{*}$ : protrochanter ventrally with fine and short carina in the middle; mesotrochanter with a flat and apically obtuse tooth; metatrochanter with a long and narrow carina; aedeagus (Fig. 157) $0.28 \mathrm{~mm}$ long; internal sac with a broad, flat, and sinuous sclerite and with a long sinuous structure; parameres apically with three setae.

Comparative notes: Like the other Cretan representatives of the genus, A. occidens is reliably identified only based on the modifications of the male trochanters and on the internal structures of the aedeagus.

Distribution and natural history: This species is probably locally endemic to the extreme west of Crete. The specimens were found in two localities by washing soil from a moist stony slope with very old chestnut and from a stream valley with old chestnut at altitudes of 410 and $560 \mathrm{~m}$.

\section{Amauronyx askifouicus BRACHAT spec. nov. urn:Isid:zoobank.org:act:7CE4D2AD-8F1E-408A-9112-5301AC6CC6AE (Fig. 158)}

Type material: Holotype $0^{*}$ : "GR - Crete [41], Askifou

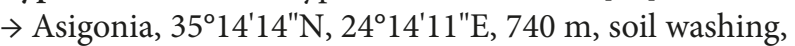
23.III.2018, V. Assing / Amauronyx askifouicus spec. nov. $\sigma^{\star}$, det. Brachat 2.2019 / Holotypus" (cBra). Paratypes: $10^{7}, 3$ 우 옹 same data as holotype (cBra).

Etymology: The specific epithet is an adjective derived from the name of the plateau where the type locality is situated.

Description: External characters as in A. occidens; distinguished only by the male sexual characters:

$\sigma^{*}$ : pro- and mesotrochanter with fine, metatrochanter with short oblong carina; aedeagus $0.30 \mathrm{~mm}$ long; inter- nal sac with a broad, flat, and laterally triangular sclerite and with a long and slender angled structure; parameres apically with four setae.

Comparative notes: Amauronyx askifouicus is distinguished from other Cretan representatives of the genus by the distinctive modifications of the male trochanters and by the internal structures of the aedeagus.

Distribution and natural history: This species is probably locally endemic to the environs of the type locality in West Crete. The specimens were found by washing soil from a rocky north slope with old Quercus ilex at an altitude of $740 \mathrm{~m}$.

\section{Bryaxis meybohmianus BRACHAT spec. nov. urn:Isid:zoobank.org:act:FE6B56D3-E7A1-4F55-9587-ABC42768A1AC (Figs 159-161)}

Type material: Holotype $\sigma^{*}$ : "GR-Kreta, Bez. Chania, Samaria-Schlucht, 28.3.1983, leg Brachat/Dörnfeld / Bryaxis meybohmianus spec. nov. o det. Brachat 2.2019 / Holotypus” (cBra). Paratypes (all cBra): $3 \sigma^{\star} o^{\star}, 6$ ㅇ 9 : same data as holotype; $2 \sigma^{\star} \sigma^{*}$ : "GR-Kreta , Bez. Chania, Omalos-Samaria, 20.5.1980, leg Brachat"; 1 o": "24.3.86 Westkreta, Samaria-Schlucht, leg. H. Meybohm” (cBra);

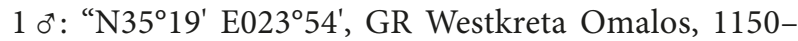
$1480 \mathrm{~m}, 13.3 .2001$ Meybohm"; $10^{\star}, 4$ 우 우: same data,

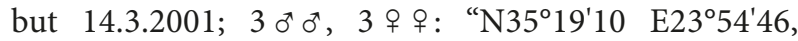
GR Westkreta (16), Omalos $1110 \mathrm{~m}, 16.3 .2018$, leg. Meybohm \& Brachat"; $2 \sigma^{\top} o^{\top}:$ same data, but 18.3.2018;

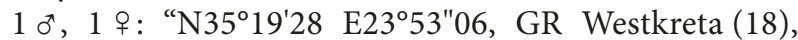
Omalos 1060 m, 17.3.2018, leg. Meybohm \& Brachat";

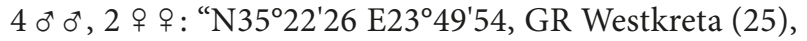
Prases w 490 m, 20.3.2018, leg. Meybohm \& Brachat";

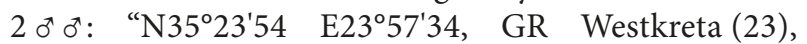
Meskla Zouvra $230 \mathrm{~m}, 19.3 .2018$, leg. Meybohm \& Brachat"; 3 ơ ơ 1 요 :N3521'31 E2349'29, GR Westkreta (30), Prases $10 \mathrm{~km}$ w Omalos $760 \mathrm{~m}, 22.3 .2018$, leg. Meybohm \& Brachat”; 1 i : “N35²5'07 E23 50'54, GR Westkreta (32), Nteres $210 \mathrm{~m}, 23.3 .2018$, leg. Meybohm \& Brachat"; 1 ơ: "N3524'33 E2350'55, GR Westkreta (34), Nteres $280 \mathrm{~m}, 23.03 .2018$, leg. Meybohm \& Brachat"; 3 우: "GR - Crete [7], SW Chania, Mavros stream valley, $35^{\circ} 24^{\prime} 10^{\prime \prime} \mathrm{N}$,

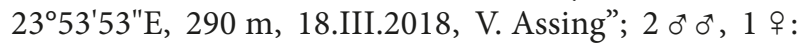
"GR - Crete [10], SW Chania, Mavros stream valley, 3524'10"N, 2353'53"E, 290 m, 24.XII.2018, V. Assing”; $12 o^{\top} o^{\star}, 7$ 우 우: “GR - Crete [14], S Kissamos, Aikirgianis, $35^{\circ} 25^{\prime} 45^{\prime \prime} \mathrm{N}, 23^{\circ} 40^{\prime} 36^{\prime \prime} \mathrm{E}, 290 \mathrm{~m}$, soil washing, 19.III.2018, V. Assing"; $10^{\star}, 1$ ㅇ: "GR - Crete [23], SW Chania, SW Prases, $35^{\circ} 21^{\prime} 45^{\prime \prime} \mathrm{N}, 23^{\circ} 48^{\prime} 59^{\prime \prime E}, 800 \mathrm{~m}$, soil washing, 20.III.2018, V. Assing"; 1 \%: "GR - Crete

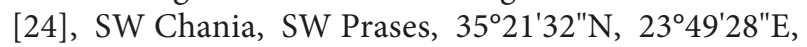
$740 \mathrm{~m}$, soil washing, 20.III.2018, V. Assing"; $10^{\star}, 1$ \% : "GR - Crete [25], SW Chania, SW Prases, 35²1'43"N, $23^{\circ} 49^{\prime} 24$ "E, 640 m, soil washing, 20.III.2018, V. Assing”; 
$10^{\top}, 1$ i: "GR - Crete [31], S Kissamos, NE Elos, $35^{\circ} 22^{\prime} 04^{\prime \prime N}, 23^{\circ} 38^{\prime} 19^{\prime \prime E}, 460 \mathrm{~m}$, soil washing, 21.III.2018, V. Assing"; 1 : "GR - Crete [38], SW Chania, S Nteres, $35^{\circ} 24^{\prime} 15^{\prime \prime} \mathrm{N}, 23^{\circ} 50^{\prime} 58^{\prime \prime E}, 330 \mathrm{~m}$, soil washing, 22.III.2018, V. Assing"; 1 \%: "GR - Crete [46], SW Chania, N Nteres, 352 $27^{\prime} 40^{\prime \prime} \mathrm{N}, 23^{\circ} 50^{\prime} 19^{\prime \prime} \mathrm{E}, 170 \mathrm{~m}$, soil washing, 24.III.2018, V. Assing"; $10^{\star}:$ "GR - Crete [49], N Kandanos, Floris, 352 $22^{\prime} 56^{\prime \prime} \mathrm{N}, 23^{\circ} 44^{\prime} 00^{\prime E}$, $590 \mathrm{~m}$, soil washing, 25.III.2018, V. Assing”; 1 : : "GR - Crete [50], E Kandanos, Anisaraki, $35^{\circ} 19^{\prime} 53^{\prime \prime} \mathrm{N}, 2^{\circ} 45^{\prime} 34^{\prime \prime E}, 560 \mathrm{~m}$, soil washing, 25.III.2018, V. Assing"; $10^{*}$ : "GR - Crete [51],

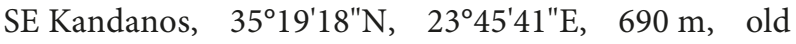
oak tree, soil washing, 25.III.2018, V. Assing"; 3 우 우: “N35 $21^{\circ} 56$ E2337'16, GR Westkreta (13), Louchi 550 m, 20.III.2019, leg. Meybohm \& Brachat"; $2 o^{\text {đ }} o^{\text {T }}$, 4 우 우: “N3524'01 E2351'01, GR Westkreta (19), S Nteres 340 m, 24.III.2019, leg. Meybohm \& Brachat";

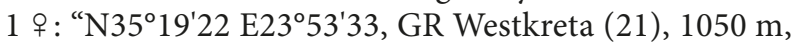
S Omalos, 25.III.2019, leg. Meybohm \& Brachat”.

Etymology: This species is dedicated to my friend and colleague Heinrich Meybohm.

Description: Body length $1.50-1.65 \mathrm{~mm}$. Coloration: body reddish-brown, glossy. Pubescence rather sparse, yellowish, and suberect, with scattered longer setae. Head weakly transverse, approximately 1.1 times as broad as long; vertex with median keel, this keel interrupted anteriorly and forming an acute tooth-like process; frontal lobe $0.16 \mathrm{~mm}$ broad; temples rounded. Eyes small, composed of 4-10 ommatidia. Antenna relatively short, 0.64-0.65 mm long; antennomeres III distinctly, IV weakly oblong, V-VII approximately as long as broad, VIII weakly transverse, IX and X distinctly transverse, and XI larger, nearly twice as long as broad. Maxillary palpomeres II and III with few tubercles, palpomere IV large, weakly petiolate, approximately three times as long as broad.

Pronotum 1.1 times as broad as long, 1.2 times as long, and as broad as head, broadest in anterior third; between posterior margin and ante-basal sulcus with more or less distinct punctation and with median keel, this keel reaching slightly beyond ante-basal sulcus.

Elytra 1.15 times as broad as long, with weakly marked humeral angle; punctation fine and sparse, towards posterior margin more distinct and denser. Hind wings completely reduced. Legs slender with slightly dilated femora.

$\sigma^{\star}$ : scapus strongly dilated, approximately 1.3 times as long as broad, with a tubercle on the inner face; pedicel weakly oblong, inner face with fine and narrow keel (Fig. 159); ventral aspect of head with transverse gular impression of semicircular shape, its anterior margin medially triangularly elevated (well visible in lateral view); metaventrite in postero-median portion weakly concave, slightly impressed posteriorly; tergite VIII with posterior margin weakly bent upwards; pro- and metafemora of variable shape, slightly to strongly dilated; protibia with a more or less distinct excision in apical third; metatibia with a distinct inner apical spine; aedeagus (Figs 160-161) 0.44$0.49 \mathrm{~mm}$ long, with 3-5 sclerotized spines in internal sac. ㅇ: scapus twice as long as broad; pedicel cylindrical, slightly narrower and distinctly shorter than scapus; metaventrite in postero-median portion flattened; legs unmodified.

Intraspecific variation: One of the type males has conspicuously dilated femora, distinctly dilated and flatted metatibiae with a deep emargination in the apical third.

Comparative notes: The similarly modified male scapus suggests that Bryaxis meybohmianus is closely allied to B. anatolicus (SAulcy, 1878) from Turkey and the Greek island Samos. It is distinguished, however, by the lateral keel on the pedicel and by the clearly different aedeagus. Aside from some unidentified females, the only other congener known from Crete is B. bulbifer (REICHENBACH, 1816), from which the new spccies differs by paler coloration, smaller eyes, and by the shapes of the male scapus, the male pedicel, and the aedeagus.

Distribution and natural history: This species is endemic to West Crete. Numerous specimens were sifted from litter in various types of forest and shrub habitats. The remainder was collected by washing soil, mostly from close to very old trees. The altitudes range from 170 to $1110 \mathrm{~m}$.

\section{Bythinus creticus BRACHAT spec. nov. urn:Isid:zoobank.org:act:5A5439A5-BB04-41D0-897E-3769BA046964 (Figs 162-163)}

Type material: Holotype $o^{\top}$ : "GR - Crete [16], Psiloritis Nida Plateau, 1510 m, SW Anogia, sifted, 35¹3'09"N, 2450'01"E, 12.IV.2014, V. Assing / Bythinus creticus spec. nov. ơ det. Brachat 2.2019 / Holotypus" (cBra).

Etymology: The specific epithet (adjective) is derived from Crete, where this species is endemic.

Description: Body length $1.22 \mathrm{~mm}$. Coloration: body dark reddish-brown, with the legs, antennae, and palpi slightly paler. Pubescence rather sparse, yellowish, and nearly depressed. Punctation of pronotum sparse and fine, that of elytra denser and less fine.

Head transverse, length $0.24 \mathrm{~mm}$, width $0.28 \mathrm{~mm}$; width of frontal lobe $0.13 \mathrm{~mm}$; vertex with median carina. Eyes large, longer than the weakly convex temples in dorsal view. Antenna short, $0.48 \mathrm{~mm}$ long, with three-jointed club; scapus longer than broad (length $0.08 \mathrm{~mm}$; width $0.06 \mathrm{~mm}$ ); pedicel oval, slightly narrower than scapus, 1.2 times as long as broad; antennomeres III-VIII distinctly narrower than I and II, III weakly transverse, IV-VIII distinctly transverse, IX and X strongly transverse and 
distinctly broader than VIII, and XI oval, 1.5 times as long as broad.

Pronotum weakly transverse (length $0.30 \mathrm{~mm}$; width $0.32 \mathrm{~mm}$ ), broadest in anterior third, with rounded lateral margins; basally with a median keel anteriorly reaching slightly beyond basal impression.

Elytra nearly as long as head and pronotum combined, weakly transverse (length $0.5 \mathrm{~mm}$; width: $0.6 \mathrm{~mm}$ ), with marked humeral angles and with short discal impression. Hind wings present. Legs slender. Abdomen short, $0.17 \mathrm{~mm}$ long.

$0^{*}$ : head ventrally with deeply bordered transverse impression, this impression anteriorly excised and with a cluster of setae on either side; maxillary palpomere IV approximately twice as long as broad (length $0.16 \mathrm{~mm}$; width $0.09 \mathrm{~mm}$ ), medio-dorsally with a shallow depression with a flat tubercle directed towards apex of palpomere (Fig. 162); metatibia near apex with a minute spine; aedeagus $0.24 \mathrm{~mm}$ long and shaped as in Fig. 163.

ㅇ: unknown. According to Besuchet (pers. comm.), Paganetti-Hummler collected a Bythinus female in Crete, which may belong to this species.

Comparative notes: Bythinus creticus belongs to the species group of B.hopffgarteni ReITTER, 1882 and is similar to B. parvipenis Meggiolaro, 1966 (Cyprus and South Turkey) and B. vicinides NewTon, 2015 (Southeast Turkey, Lebanon). It is distinguished from both of them by the shape of the tubercle on palpomere IV and by less curved lateral internal structures of the aedeagus, from $B$. vicinides additionally by the unmodified pedicel.

Distribution and natural history: The type locality is situated in the Psiloritis range, Central Crete. The holotype was collected by sifting litter and grass roots in a north slope with scattered oak trees at an altitude of $1510 \mathrm{~m}$.

\section{Euplectus assingi BRACHAT spec. nov. urn:Isid:zoobank.org:act:B653CFCD-0DF4-4AC8-8BDC-64FCD2FB9599 (Fig. 164)}

Type material: Holotype $\sigma^{*}$ : "GR - Crete [18], SW Sitia,

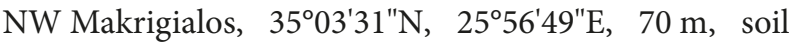
washing, 30.XII.2017, V. Assing / Euplectus assingi spec. nov. ơ, det. Brachat 2.2019 / Holotypus" (cBra). Paratypes: $10^{\text {* }, ~} 2$ ㅇ 우: “GR - Crete [17], SW Sitia, Kimouriotis, $35^{\circ} 10^{\prime} 40^{\prime \prime} \mathrm{N}, 26^{\circ} 03^{\prime} 00^{\prime \prime} \mathrm{E}, 110 \mathrm{~m}$, soil washing, 28.XII.2017, V. Assing" (cBra); 1 o, 2 ㅇ o : same data, but 15.III.2019, leg. Meybohm \& Brachat (3) (cBra); 2 우 운 "GR - Crete [13], Kritsa, 350' $47^{\circ} \mathrm{N}, 25^{\circ} 38^{\prime} 24 " \mathrm{E}, 400 \mathrm{~m}$, soil washing, 27.XII.2017, V. Assing” (cBra); 1 ơ: "GR Crete [15], Kritsa, SW Kroustas, 350 $7^{\prime} 02^{\prime \prime N}, 25^{\circ} 38^{\prime} 14$ "E, $760 \mathrm{~m}$, soil washing, 27.XII.2017, V. Assing" (cBra); 1 : "GR - Crete [56], NE Lassithi Plateau, 3512'45"N, $25^{\circ} 31^{\prime} 53 " \mathrm{E}, 850 \mathrm{~m}$, soil washing, 27.III.2018, V. Assing”
(cBra); $10^{\text {*: }}$ "Greece - Crete, above Ammoudari, sifting 980 m, 35.305663N, 24.175005E, 21.4.2015 M. Kocian lgt." (cHla).

Etymology: This species is dedicated to Volker Assing, who, especially by means of the soil-washing technique, succeeded in discovering this and other new species of Cretan Pselaphinae.

Description: Body length 1.55-1.60 mm. Body reddishbrown with slightly paler legs, smooth, glossy, and with relatively short and nearly depressed yellowish pubescence; antennae with long and erect setae.

Head transverse, 1.3 times as broad as long, dorsally with a pair of postantennal foveae and a pair of intraocular foveae, the latter at the level of the posterior margins of the eyes and close, distance between them less than distance between fovea and dorsal margin of eye; frons between antennal insertions with deep impression; median keel on vertex relatively long. Eyes large, composed of 30-35 ommatidia, and projecting from lateral contours of head. Antenna with large and distinct three-jointed club; antennomeres I and II weakly oblong, III smaller, as long as broad and narrower at base, IV-VI as broad as long and orbicular, VII and VIII weakly transverse, shape of club sexually dimorphic.

Pronotum as long as broad and as broad as head, broadest in anterior third; lateral margins convex; disc with median sulcus not reaching anterior margin of pronotum.

Elytra as long as broad and slightly more than 1.5 times as long as pronotum, with four basal foveae; discal sulcus deep, less than half as long as elytron. Hind wings present.

Abdominal tergites IV and V each with two basal keels not reaching middle of tergites, area between these keels approximately half as broad as tergites and with dense and very short pubescence.

$\mathrm{o}^{\star}$ : antenna $0.63-68 \mathrm{~mm}$ long; antennal club large, $0.28 \mathrm{~mm}$ long, slightly longer than combined length of antennomeres III-VIII; antennomeres IX as long as broad, broader and longer than preceding antennomeres, $\mathrm{X}$ weakly oblong, and XI twice as long as broad; mesotibia subapically with small spine on inner face; sternite VIII with shallow median impression, laterally of this impression with a series of short setae; aedeagus (Fig. 164) $0.25-0.27 \mathrm{~mm}$ long.

\%: antenna $0.62-0.63 \mathrm{~mm}$ long; antennal club $0.24 \mathrm{~mm}$ long, as long as the combined length of antennomeres III-VIII; antennomeres IX twice as broad as long, X 1.25 times as broad as long, and XI large, 1.6-1.7 times as long as broad.

Comparative notes: Euplectus assingi belongs to a group of species including Euplectus meybohmi BRACHAT, 2017 from the Greek island Samos and several undescribed species of the East Mediterranean region, which are characterized by a distinct sexual dimorphism of the antennal club and 
a deep impression between the antennal insertions. It is distinguished from E. meybohmi and other species of this group particularly by the shape of the aedeagus.

Two additional Euplectus species recorded from Crete are represented exclusively by females, so that they remain undescribed until males are available.

Distribution and natural history: The species is endemic to Crete. Unlike most other congeners which are generally found associated with wood, the specimens of E. assingi were, with one exception, all collected by washing soil from the vicinity of old trees. The altitudes range from 70 to $980 \mathrm{~m}$.

\section{Genus Faronus AuBÉ, 1844}

Previously, only one species of this Mediterranean genus had been recorded from Crete, F. lafertei AubÉ, 1844 (Blattný \& Blattný 1916). Since the distribution of A. lafertei is confined to the West Mediterranean, this record undoubedly refers to F. parallelus BESUCHET, 1958, a widespread East Mediterranean species. Three additional species, all of them endemic to the Lefka Ori, West Crete, are described below.

Many Faronus species are subject to remarkable intraspecific variation, particularly of the number and position of impressions on the pronotum and the elytra, the length of the hind wings, and even of the shape of the aedeagus. The latter is often inverted (mirrored).

\section{Faronus meybohmi BRACHAT spec. nov. urn:Isid:zoobank.org:act:B80022A7-78AC-45E9-94A6-B3A31657DCF7 (Fig. 165)}

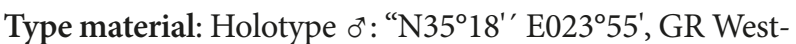
kreta, Omalos, Gingolos, 1500 m, Meybohm 20.4.2000 / Faronus meybohmi spec. nov. o", det. Brachat 2.2019/ Holotypus" (cBra). Paratypes: 3 ơ ơ, 6 우 우 “GR - Kreta, Bez. Chania, Omalos Hochfläche, 21.-22.5.1980, leg. Brachat" (cBra); 1 \%: "24.3.86 West Kreta, Omalos Hochfläche, leg. H. Meybohm” (cBra); 2 o $^{\star}$ o $^{*}$ : "24.3.86 West Kreta, Samaria Schlucht, leg. H. Meybohm” (cBra); 2 우 우: "N3519' E0235' GR Westkreta, Omalos 1150-1480 m, Meybohm, 13.3.2001” (cBra); 1 o $^{\top}, 1$ ㅇ: "N3519' E2351' GR Westkreta, Omalos-West, 1100 m, Meybohm, 14.3.2001" (cBra); $2 o^{\star} o^{\star}, 1$ 우 : "GR - Kreta, Bez. Chania, Samaria-Schlucht, 28.3.1983, leg. Brachat/Dörnfeld” (cBra); 1 ㅇ: "GR - Crete [3] Lefka Ori, E Kallergi Refuge, $35^{\circ} 19^{\prime} 38^{\prime \prime N}$, 235' $10^{\circ}$ "E, $1450 \mathrm{~m}$, litter \& grass, 17.III.2018, V. Assing” (cBra); $20^{*} \mathrm{o}^{\text {*ै, }}$

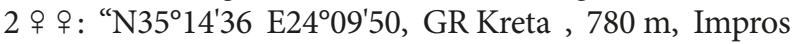
S, 22.3.2019, leg. Meybohm \& Brachat (16)" (cBra); $10^{\text {T, }}$ 2 우 ㅇ: “N35 ${ }^{\circ} 19^{\prime} 07 \mathrm{E} 23^{\circ} 54^{\prime} 46$, GR Kreta, $1060 \mathrm{~m}$, Omalos E, 23.3.2019, leg. Meybohm \& Brachat (17)" (cBra);

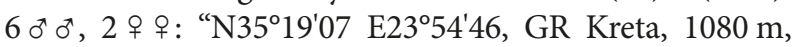
Omalos E, 25.3.2019, leg. Meybohm \& Brachat (20)" (cBra); 2 우 ㅇ: “N3519'22 E2353'33, GR Kreta, 1050 m,
Omalos S, 25.3.2019, leg. Meybohm \& Brachat (21)" (cBra); 1 o , 1 ㅇ: "Greece - Crete, above Ammoudari, sifting $980 \mathrm{~m}, 35.305663 \mathrm{~N}, 24.175005 \mathrm{E}, 21.4 .2015$ M. Kocian lgt." (cHla), 1 o': "Greece - Crete, Lefka Ori, Omalos env., sifting, $1100 \mathrm{~m}, 35.359734 \mathrm{~N}, 23.915940 \mathrm{E}, 20.4 .2015$, M. Kocian lgt." (cHla); 5 ㅇ ㅇ: "Greece - Crete, Lefka Ori, Omalos env., sifting, 35.357024N 23.922297E, 24.4.2015, M. Kocian lgt.“(cHla).

Etymology: This species is dedicated to my friend and field companion Heinrich Meybohm.

Description: Body length $1.5-1.7 \mathrm{~mm}$. Body pale reddish-brown with short and nearly depressed pubescence; vertex with two longer erect setae.

Head distinctly transverse, nearly 1.5 times as broad as long, and of triangular shape (length $0.22-0.26 \mathrm{~mm}$; width $0.32-0.36 \mathrm{~mm}$ ); temples obtusely angled, projecting, and apically with a small circular or oval impression. Eyes large, approximately as long as temples in dorsal view, weakly convex, weakly protruding from lateral contours of head. Antenna with three-jointed club, rather short (length $0.55-0.63 \mathrm{~mm}$ ); antennomeres I nearly twice as long as broad, II slightly narrower, oval, indistinctly oblong, III minute, IV-VII orbicular, VIII weakly transverse, IX-XI broader, IX and X transverse, XI weakly oblong, slightly shorter than the combined length of IX and X.

Pronotum $0.30 \mathrm{~mm}$ long and $0.37-0.38 \mathrm{~mm}$ broad, slightly longer and broader than head, broadest in the middle, with convex lateral margins, more strongly tapering posteriad than anteriad, with two ante-basal and two lateral foveae; disc with U-shaped impression in posterior half, bottom of this impression and sometimes laterad of this impression with additional foveae.

Elytra short, as long as pronotum and 1.5 times as broad as long (length $0.29-0.34 \mathrm{~mm}$; width $0.44-0.50 \mathrm{~mm}$ ), with $2-3$ basal impressions, discal sulcus reaching middle of elytra; humeral angles indistinctly marked, with more or less pronounced longitudinal impression directed posteriad. Hind wings completely reduced.

$\sigma^{*}$ : metafemora strongly dilated; metatrochanter ventrally enlarged and with flattened margins; metatibia with small apical spine; genital plate (sternite IX) of oval shape; aedeagus (Fig. 165) $0.36-0.40 \mathrm{~mm}$ long, occasionally inverted.

Comparative notes: Faronus meybohmi is distinguished from the widespread F. parallelus and from F. distinctus Besuchet, 1999 (Lesbos, Samos, Rhodos, Southwest Turkey) by distinctly shorter and more transverse elytra, dilated male metafemora, and by the shape of the aedeagus.

Distribution and natural history: The known distribution is confined to the Lefka Ori region, West Crete. The specimens were collected by sifting leaf litter and grass roots at altitudes of $780-1500 \mathrm{~m}$. 
Faronus lefkamontium BRACHAT spec. nov. urn:Isid:zoobank.org:act:B5C36287-54F6-4CF0-B2BF-E3D8E4AF1029 (Fig. 166)

Type material: Holotype o : $^{\circ} \mathrm{N} 35^{\circ} 19^{\prime} \mathrm{E} 023^{\circ} 51^{\prime}$, GR Westkreta, Omalos-West, $1100 \mathrm{~m}$, Meybohm 14.3.2001 / Faronus lefkamontium spec. nov. O', det. Brachat 2.2019 / Holotypus" (cBra). Paratypes (all in cBra): 1 o $^{\star}, 1$ \% : "24.3.86 West Kreta, Omalos Hochfläche, leg. H. Meybohm”; 1 : “GR-Kreta, Bez. Chania, Omalos Hochfläche, 21.-22.5.1980 leg. Brachat”; 1 : "N35¹9' E0235', GR Westkreta, Omalos, 1150-1480 m, Meybohm 13.3.2001".

Etymology: The name is a noun composed of Lefka (the name of the mountain range where the type locality is situated) and the genitive of the Latin noun mons (mountain). The Greek word Ori denotes mountains.

Description: External characters as in F.meybohmi, except as follows:

Body length $1.5-1.6 \mathrm{~mm}$. Head 0.22-0.24 mm long and $0.32-0.34 \mathrm{~mm}$ broad; temples rectangularly projecting and apically with a small oval impression. Eyes large, at least as long as postocular region in dorsal view, more strongly convex and more distinctly protruding from lateral contours of head. Pronotum $0.28-0.30 \mathrm{~mm}$ long and $0.36-0.38 \mathrm{~mm}$ broad, significantly longer and slightly broader than head. Elytra $0.31-0.35 \mathrm{~mm}$ long and $0.42-$ $0.44 \mathrm{~mm}$ broad, 1.3 times as broad as long and 1.1 times as long as pronotum. Hind wings completely reduced.

$o^{7}$ : antenna $0.64-0.68 \mathrm{~mm}$ long; tibia with minute apical spine; metatrochanter and metafemora unmodified; aedeagus (Fig. 166) $0.36 \mathrm{~mm}$ long, occasionally inverted.

o : antenna 0.56-0.60 $\mathrm{mm}$ long.

Comparative notes: Faronus lefkamontium is distinguished from the otherwise similar F. meybohmi only by more convex eyes, unmodified male metatrochanters and metafemora, as well as by the shape of the aedeagus.

Distribution and natural history: At present, F. lefkamontium is known only from the Omalos region in the Lefka Ori. The specimens were sifted from litter and grass roots at altitudes of at least $1100 \mathrm{~m}$.

\section{Faronus albimontium BRACHAT spec. nov.} urn:Isid:zoobank.org:act:9E7893E5-D3A1-4387-B179-AA51AB793FED (Fig. 167)

Type material: Holotype $0^{\star}$ : “GR - Westkreta (19), N35¹9'08 E2355'10, Omalos, $1200 \mathrm{~m}$, 17.3.2018, leg. Meybohm \& Brachat / Faronus albimontium spec. nov. $0^{*}$, det. Brachat 2.2019 / Holotypus" (cBra). Paratypes: $1 \sigma^{\star}$,

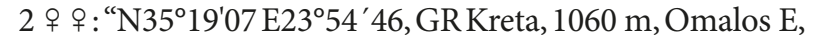
23.3.2019, leg. Meybohm \& Brachat (17)” (cBra).
Etymology: The name is a Latin noun in the genitive plural and denotes "of the White Mountains". It alludes to the fact that the distribution is probably confined to the Lefka Ori (English: White Mountains).

Description: External characters as in F. meybohmi and F. lefkamontium, except as follows:

Body length 1.5-1.6 mm. Head 0.22-0.24 mm long and $0.32-0.34 \mathrm{~mm}$ broad; temples rectangularly projecting, apically with a small circular impression. Eyes large, distinctly convex. Antenna $0.56-0.58 \mathrm{~mm}$ long. Pronotum $0.26-0.28 \mathrm{~mm}$ long and $0.33-0.36 \mathrm{~mm}$ broad, significantly longer and slightly broader than head. Elytra $0.27-0.29 \mathrm{~mm}$ long and $0.42-0.45 \mathrm{~mm}$ broad, 1.5 times as broad as long. Hind wings completely reduced.

$\sigma^{\top}$ : metatrochanter ventrally with a knife-shaped dilatation; metatibia with a small apical spine; femora unmodified, not dilated; aedeagus (Fig. 167) 0.30$0.31 \mathrm{~mm}$ long; right paramere with one, left paramere with two apical setae.

Comparative notes: Among the Cretan representatives of the genus, this species is characterized particularly by the shape of the head, shorter elytra, and by the male primary and secondary sexual characters.

Distribution and natural history: Like F. lefkamontium, F. albimontium has been recorded only from the environs of Omalos in the Lefka Ori. The specimens were sifted from litter and grass roots at altitudes of 1060 and $1200 \mathrm{~m}$.

\section{Tychus chanianus BRACHAT spec. nov. urn:Isid:zoobank.org:act:85D07E45-AEE2-4D13-9C26-18B353D1AD15 (Fig. 168)}

Type material: Holotype $0^{\top}$ : "GR-Westkreta (25), N35²2'26 E2349'54, Prases w 490 m, 20.3.2018, leg. Meybohm \& Brachat / Tychus chanianus spec. nov. $0^{*}$, det. Brachat 2.2019 / Holotypus" (cBra). Paratypes (all in cBra): $1 o^{\star}$ : same data as holotype; $10^{\star}$ : “N35 $22^{\prime} \mathrm{E} 023^{\circ} 50^{\prime}$, GR Westkreta, Prases 550 m, Meybohm 14.3.2001”.

Etymology: The specific epithet is derived from Chania, the prefecture where the type specimens were found.

Description: Body length $1.4 \mathrm{~mm}$. Body reddish-brown with slightly paler legs and yellowish palpi, glossy, smooth, with sparse and short pubescence, and with few longer setae.

Head as long as broad (length and width $0.26 \mathrm{~mm}$ ), with narrow median sulcus between the distinct antennal tubercles; frons with two minute lateral teeth and at the level of the anterior margin of the eyes with two small intraocular foveae. Eyes large, composed of 15-18 ommatidia, and projecting from lateral contours of head. Maxillary palpomere IV $0.9 \mathrm{~mm}$ long and $0.5 \mathrm{~mm}$ wide. 
Pronotum broader than long (length $0.29 \mathrm{~mm}$; width $0.32 \mathrm{~mm}$ ), distinctly broader than head and broadest slightly behind middle; baso-lateral foveae distinct and deep.

Elytra 1.3 times as broad as long and with weakly marked humeral angles, each with two basal foveae; discal series extending to middle of elytra. Hind wings present.

Abdominal tergite IV $0.15 \mathrm{~mm}$ long, with a pair of short keels, area between these keels approximately two-fifths as wide as breadth of tergite, weakly impressed, pubescent, and with a pair of baso-lateral foveae.

$\sigma^{*}$ : antenna compact, $0.68-0.70 \mathrm{~mm}$ long, with large three-jointed club (length $0.28 \mathrm{~mm}$ ); scapus 1.25 times as long as broad; pedicel narrower and of oval shape; antennomeres III slightly narrower than II and weakly oblong, IV narrower than III and orbicular, V slightly broader than IV and orbicular, VI smaller than V and weakly transverse, VII longer and broader than VI, VIII short and strongly transverse, IX and X transverse and longer, and XI of ovoid shape, 1.3 times as long as broad, and as long as the combined length of VIII-X; legs slender with weakly dilated femora; mesotrochanter with distinct spine at posterior margin; mesotibia with minute subapical spine; metaventrite posteriorly with distinct median impression; abdominal sternite IV with a pair of minute keels furnished with dense setae; aedeagus (Fig. 168) $0.29 \mathrm{~mm}$ long.

ㅇ: unknown.

Intraspecific variation: In one of the paratypes (collected at $550 \mathrm{~m}$ ), the left paramere is straight, whereas it is curved in the other two males.

Comparative notes: Tychus chanianus is most closely allied to T. lagrecai SABella, 2002 from Central Crete and belongs to the T. dalmatinus species group. It is distinguished from T. lagrecai by slightly smaller size (T. lagrecai: body length $1.45-1.65 \mathrm{~mm}$ ) and by an additional spine in the apical third of the dorsal apophysis of the aedeagus.

Distribution and natural history: The known distribution is confined to two localities in the environs of Prases, West Crete. The specimens were sifted from litter on stony soil at altitudes of 490 and $550 \mathrm{~m}$.

\section{Tachyporinae}

\section{Sepedophilus creticus ScHüLKE spec. nov. urn:Isid:zoobank.org:act:F2B971D6-B222-4823-A1BB-DF4B816F0775 (Figs 169-173)}

Type material: Holotype $\sigma^{\top}$ : “GR Crete 25.8.-5.9.2018, prefecture Lassithi, Lassithi Plateau, 3509'53.5"N 2531'27.9"E Matějíček J. lgt. / Holotypus Sepedophilus creticus spec. nov. det. M. Schülke 2019" (coll. Schülke in MNB). Paratypes: $1 \sigma^{*}$ : same data as holotype (cMat);
2 우 오 GR - Crete 30.5.2018, Koutalioti Canyon, near streams on sand / 35 $12^{\prime} 12.1^{\prime \prime} \mathrm{N} 24^{\circ} 28^{\prime} 01.8^{\prime \prime E}$, Matějíček J. lgt." (cMat, coll. Schülke in MNB); 1 o': "GR O-Kreta, Elafounisi, 5.-11.5.1985, Heiss" (cSch); $10^{\top}$ : “GR Crete [22], WSW Ag. Nikolaos, Katharo, 350.' $58^{\prime \prime N}$, 2534'33"E 1160 m, under stones, 29.XII.2018, V. Assing"

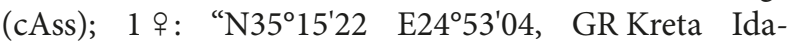
Geb. $1200 \mathrm{~m}$, Anogia-Psiloritis, 17.3.2019, Brachat \& Meybohm (7)" (cAss).

Etymology: The specific epithet is an adjective derived from Crete, where the species is probably endemic.

Description: Measurements: Head width: 0.51-0.54 mm; pronotum width: $0.88-0.94 \mathrm{~mm}$; pronotum length: $0.66-0.69 \mathrm{~mm}$; sutural length of elytra: $0.65-0.71 \mathrm{~mm}$; humeral length of elytra: $0.79-0.86 \mathrm{~mm}$; elytral width: 0.90-0.94 mm; length of forebody: $1.56-1.68 \mathrm{~mm}$; length of aedeagus: $0.71-0.73 \mathrm{~mm}$. Relative lengths of antennal segments I-XI: $9.0: 6.5: 6.0: 5.8: 5.3: 5.0: 4.8: 4.5: 4.3$ $: 4.0: 9.0$; length-width ratios of antennal segments I-XI: $3.0: 2.6: 2.4: 2.3: 1.9: 1.5: 1.2: 1.1: 0.9: 0.8: 1.6$.

Small and compact species (Fig. 169), body length 3.0-3.5 mm. Coloration: in mature specimens head, elytra and abdomen blackish-brown, pronotum slightly paler, apical margin of elytra narrowly reddish, apical margins of abdominal tergites III-VI, apical half of tergite VII, and segments VIII-X reddish. Legs, antennae, maxillary and labial palpi yellowish-brown; immature specimens of similar coloration as S. nigripennis (STEPHENS, 1832), sometimes elytra with dark scutellar marking extended along elytral suture. Hind wings fully developed. Abdominal sternites from IV to VII each with two long black bristles $(250 \mu \mathrm{m})$ at apical angles and additional bristles along apical margin. Head without microsculpture, pronotum only with traces of microsculpture, more distinct near basal margin, never forming complete meshes. Elytra with microsculpture forming irregular transverse lines between punctation, indistinct rhomboid meshes only near apex.

$\sigma^{*}$ : protarsomeres I-III slightly dilated, nearly as long as wide, tergite VIII with nearly truncate apical margin, sternite VIII (Fig. 170) with broad, not very deep emargination at apical margin, this emargination anteriorly forming an angle of about $100^{\circ}$; segments IX and $\mathrm{X}$ as in Fig. 171; aedeagus (Figs 172-173) flattened and slender, with two long and moderately distinct internal structures (Fig. 173), parameres with long and slender apices.

o : terminalia as in S. nigripennis.

Comparative notes: The new species is very similar to the two winged species of the S. pedicularius group known from the East Mediterranean, S. nigripennis and S. obtusus (Luze, 1902). It can be distinguished from S. obtusus by reduced pronotal microsculpture not forming complete transverse meshes, and from both species by a larger aedeagus $(0.55-0.65 \mathrm{~mm}$ in S. obtusus and $S$. nigripennis) with longer apices of the parameres. 
Distribution and natural history: The known distribution is confined to five localities in Crete. One of these localities is somewhat doubtful, as the specimen collected near "Elafounisi" is labeled "O-Kreta", but "Elafonissi Beach" and "Elafonisi island" are located in the extreme west of Crete. The specimens other than that collected by E. Heiss were collected near streams or on stream banks, two of them at altitudes of 1160 and $1200 \mathrm{~m}$.

\section{Acknowledgements}

Thure Dalsgaard (Zoological Museum Hamburg) helped producing the images of Pselaphinae and Scydmaeninae (exclusive of Cephennium spp.). Jürgen Vogel (Görlitz) confirmed the novelty of Atheta digitalis. Michael Schülke (Berlin) contributed the description of Sepedophilus creticus. Benedikt Feldmann (Münster) proof-read the manuscript.

\section{References}

Assing, V. 1999: A revision of the species of Geostiba Thomson 1858 from Greece and Cyprus (Coleoptera, Staphylinidae, Aleocharinae). - Linzer Biologische Beiträge 31 (2): 845-928. - https://www.zobodat.at/ pdf/LBB_0031_2_0845-0928.pdf.

Assing, V. 2000: A revision of the species of Geostiba Thomson 1858 and Paraleptusa Peyerimhoff 1901 of Greece: Supplement I, including some species from Albania, Macedonia, Bulgaria, and Turkey (Coleoptera: Staphylinidae, Aleocharinae). - Linzer Biologische Beiträge 32 (2): 1007-1031. - https:// www.zobodat.at/pdf/LBB_0032_2_1007-1031.pdf.

Assing, V. 2001: A revision of the species of Geostiba Thоmson of the Balkans and Turkey. V. New species, a new synonym, new combinations, and additional records (Coleoptera: Staphylinidae, Aleocharinae). Linzer Biologische Beiträge 33 (2): 689-707. - https:// www.zobodat.at/pdf/LBB_0033_2_0689-0707.pdf.

Assing, V. 2005: Two new species and new records of Staphylinidae from the Greek island Lesbos (Insecta: Coleoptera). - Linzer Biologische Beiträge 37 (2): 1035-1046. - https://www.zobodat.at/pdf/ LBB_0037_2_1035-1046.pdf.

Assing, V. 2006a: New species and records of Staphylinidae from Greece, with two new synonymies (Insecta: Coleoptera). - Linzer Biologische Beiträge 38 (1): 333-379. - https://www.zobodat.at/pdf/ LBB_0038_1_0333-0379.pdf.

Assing, V. 2006b: New species and records of Pseudobium Mulsant \& Rey (Insecta: Coleoptera: Staphylinidae: Paederinae). - Linzer Biologische Beiträge 38 (1): 385-391. - https://www.zobodat.at/ pdf/LBB_0038_1_0385-0391.pdf.
Assing, V. 2007: Four new species and additional records of Geostiba from Turkey and Crete, and a new synonymy (Coleoptera: Staphylinidae, Aleocharinae). - Linzer Biologische Beiträge 39 (2): 777-790. - https://www.zobodat.at/pdf/LBB_0039_2_07770790.pdf.

Assing, V. 2013: On the Staphylinidae (Coleoptera) of Crete, Greece. - Stuttgarter Beiträge zur Naturkunde A, Neue Serie 6: 83-102. - https://www. zobodat.at/pdf/Stuttgarter-Beitraege-Naturkunde_ NS_6_A_0083-0102.pdf.

Assing, V. 2015: On the Staphylinidae (Coleoptera) of Crete II. Seven new species, a new synonymy, and additional records. - Stuttgarter Beiträge zur Naturkunde A, Neue Serie 8: 95-112. - https://www. zobodat.at/pdf/Stuttgarter-Beitraege-Naturkunde NS_8_A_0095-0112.pdf.

Assing, V. 2016: On the Staphylinidae of the Greek island Lesbos II, with supplementary notes on the fauna of Samos and Chios (Coleoptera: Staphylinidae). Koleopterologische Rundschau 86: 103-138. - https:// www.zobodat.at/pdf/KOR_86_2016_0103-0138.pdf.

Assing, V. 2017: On the Staphylinidae of the Greek island Ikaría, with supplementary notes on the fauna of Samos (Coleoptera: Staphylinidae). Koleopterologische Rundschau 87: 89-116. - https:// www.zobodat.at/pdf/KOR_87_2017_0089-0116.pdf.

Assing, V. 2018a: Revision of the Cousya species of the West Palaearctic Region (Coleoptera: Staphylinidae: Aleocharinae). - Integrative Systematics 1: 79-127. https://bioone.org/journalArticle/Download?fullDO $\mathrm{I}=10.18476 \% 2$ Finsy.v01.a9.

Assing, V. 2018b: On the Staphylinidae of Crete III. The first records of endogean fauna (Coleoptera: Staphylinidae: Leptotyphlinae, Aleocharinae). Linzer Biologische Beiträge 50 (1): 7-15. - https:// www.zobodat.at/pdf/LBB_0050_1_0007-0015.pdf.

Assing, V. 2019: Monograph of the Staphylinidae of Crete (Greece). Part I. Diversity and endemism (Insecta: Coleoptera). - Contributions to Entomology 69 (2): 197-238.

Blattný, W. \& Blattný, C. 1916: Die von PaganettiHummler im Jahre 1914 auf einer Forschungsreise in Kreta gesammelten Pselaphiden und Scydmaeniden. - Zeitschrift für Wissenschaftliche Insektenbiologie. Beilage Neue Beiträge zur Systematischen Insektenkunde 1: 1-6.

Castellini, G. 1996: Revisione del genere Leptomastax Pirazzolli, 1855 (Coleoptera, Scydmaenidae). - Atti del Museo Civico di Storia Naturale di Grosseto 15 (Suppl.) [1994]: 1-137.

Coiffait, H. 1972: Coléoptères Staphylinidae de la région paléarctique occidentale. I. Généralités, sous-familles: Xantholininae et Leptotyphlinae. - Supplément à la Nouvelle Revue d'Entomologie 2 (2): 1-651. 
Coiffait, H. 1979: Nouveaux Staphylidae [sic] endogés anophtalmes [sic]. - Nouvelle Revue d'Entomologie 9 (4): 313-316.

JALOSZYŃski, P. \& STEVANOVić, M. 2015: A new Cephennium of Kyrgyzstan, with notes on subgenera and distribution (Coleoptera, Staphylinidae, Scydmaeninae). - Zootaxa 3973 (2): 381-390.

Меувонм, H. 2017: [New taxa]. - In: Assing, V. 2017: On the Staphylinidae of the Greek island Ikaría, with supplementary notes on the fauna of Samos (Coleoptera: Staphylinidae). - Koleopterologische Rundschau 87: 89-116. - https://www.zobodat.at/ pdf/KOR_87_2017_0089-0116.pdf.
Schülke, M. \& Smetana, A. 2015: Staphylinidae, pp. 304-1134. - In: LöBL, I. \& LöBL, D. (eds), Catalogue of Palaearctic Coleoptera. New, updated Edition. Volume 2. Hydrophiloidea - Staphylinoidea. Revised and updated edition. - Leiden: Brill: xxvi + $1702 \mathrm{pp}$.

Zerche, L. 1999: Die westpaläarktischen Arten der Oxypoda-Untergattung Mycetodrepa Thomson. Beiträge zur Entomologie 49 (2): 261-294. - https:// www.contributions-to-entomology.org/article/ view/1498/1497. 